\title{
Caio Abujadi
}

\section{Estimulação Magnética Transcraniana em indivíduos com autismo}

\author{
Dissertação apresentada à Faculdade de \\ Medicina da Universidade de São Paulo para \\ obtenção de título de Mestre em Ciências \\ Programa de Psiquiatria \\ Orientador: Prof. Dr. Marco Antônio Marcolin
}

(Versão corrigida. Resolução CoPGr 6018/11, de 1 de novembro de 2011.

A versão original está disponível na Biblioteca da FMUSP)

São Paulo

2013 
Dados Internacionais de Catalogação na Publicação (CIP)

Preparada pela Biblioteca da

Faculdade de Medicina da Universidade de São Paulo

Creprodução autorizada pelo autor

Abujadi, Caio

Estimulação Magnética Transcraniana em indivíduos com autismo / Caio Abujadi. -- São Paulo, 2013.

Dissertação(mestrado)--Faculdade de Medicina da Universidade de São Paulo.

Programa de Psiquiatria.

Orientador: Marco Antonio Marcolin.

Descritores: 1.Transtorno autístico/tratamento 3.Comportamento restrito e repetitivo 4.Comportamento compulsivo 5.Estimulação magnética transcraniana 6.Theta Burst

USP/FM/DBD-304/13 


\section{Caio Abujadi}

\section{Estimulação Magnética Transcraniana em indivíduos com Autismo}

Súmula para apresentação de dissertação para o título

de mestrado no Departamento de Psiquiatria da Faculdade de Medicina da Universidade de São Paulo.

Área de Concentração:

Psiquiatria/ Neuromodulação/ Autismo

Orientador: Prof. Dr. Marco Antônio Marcolin

São Paulo

2013 
Autor: ABUJADI, Caio

Título: Estimulação Magnética Transcraniana em Indivíduos com Autismo

Súmula apresentada no Departamento de Psiquiatria da faculdade de Medicina da Universidade de São Paulo para obtenção do Título de Mestrado.

Aprovado em:

Banca Examinadora

Prof. Dr.: Instituição:

Julgamento: Assinatura:

Prof. Dr.: Instituição:

Julgamento: Assinatura:

Prof. Dr.: Instituição:

Julgamento: Assinatura: 
"Você nunca sabe o resultado que virá de uma ação sua. Mas se não fizer nada, não existirão resultados." Mahatma Ghandi 


\section{Agradecimentos}

Não há como deixar de pensar em todos que fazem parte de nosso desenvolvimento em fases tão importantes e difíceis de nossas vidas. Ao analisarmos o virtuoso resultado final de um processo tão árduo, de anos de trabalho, pensamos em todos aqueles que foram imprescindíveis para que cada etapa fosse completada. Ensinamentos, motivação, inspiração, conforto, correção, indagação, suposição, afago, cobrança. Momentos alegres e turbulentos. Fases tranquilas e difíceis. Perdas e ganhos. Meus caros, o resultado final dessa fase tão importante de minha vida foi alavancado por todos.

A minha amada Companheira. Com um simples olhar consegue fazer-me completo. Sempre firme em apoiar-me a terminar. Mesmo em momentos em que o apego à desistência pairava sobre minha mente. Mesmo tendo que enfrentar a distância de minha ausência em momentos tão turbulentos de nossas vidas.

A minha Família. Devo a honra de ser parte das experiências que me proporcionaram desde fases muito precoces do meu desenvolvimento. Acredito com veemência que tudo que sou advêm de muito trabalho, sofrimento e alegrias que fizeram parte de nossas vidas. Espero poder retribuir algum dia e torno esse como uma singela parte do mesmo.

Ao meu Orientador. Que com palavras sábias soube cobrar e acalmar para que os caminhos corretos fossem atingidos. A experiência protetora preocupada com nossos atos e repercussões para que nosso futuro fosse limpo e claro. Enfim, mesmo enfrentando mudanças tão severas em sua vida conseguiu transmitir-me a tranquilidade para o termino desse trabalho.

A meus companheiros de trabalho. Todos que diretamente ou indiretamente fizeram parte dessa conquista. Alguns por participar da formulação e da execução do mesmo. Outros por ter a paciência de abdicar de minha presença em momentos em que a devoção a esse trabalho exigiu exclusividade.

Aos meus professores. Todos aqueles que fizeram parte de minha formação como indivíduo e profissional. Determinadas pessoas são divisores de aguas em nossa jornada pelo conhecimento. Agradeço a todos os responsáveis por todo esse 
processo e espero poder retribuir com esse e outros trabalhos aquilo que me foi ensinado.

E finalmente, aos pacientes. Todos os que se doaram por participar desse projeto ou por ter que se sacrificar em momentos em abdiquei da clínica para dar atenção à pesquisa. A toda confiança depositada a minha pessoa, mesmo em momentos muito difíceis de minha vida. Espero sempre conseguir suprir seus anseios gerando saúde e conhecimento. 


\section{SUMÁRIO}

Lista de Siglas

Lista de Figuras

Lista de Tabelas

Lista de Gráficos

Resumo

Abstract

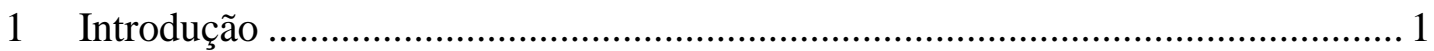

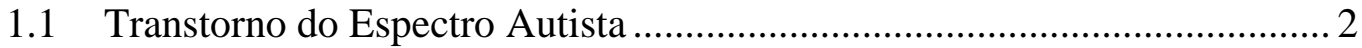

1.1.1 Aspectos Gerais ............................................................... 2

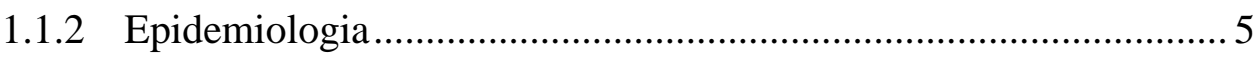

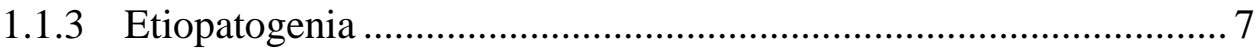

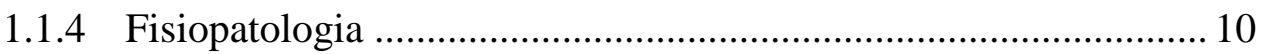

1.1.5 Neurobiologia do Comportamento Restrito e Repetitivo ............... 14

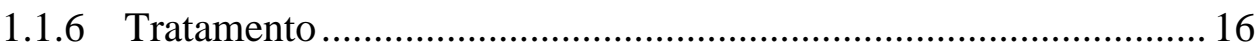

1.2 Estimulação Magnética Transcraniana (EMT) ........................................ 18

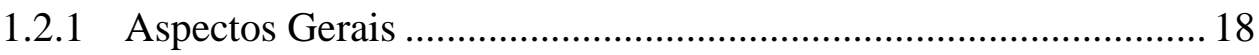

1.2.2 Estimulação em "Theta Burst” ................................................... 22

1.2.3 EMT em Crianças ................................................................... 24

1.2.4 EMT em Indivíduos com Transtorno do Espectro Autista ............25

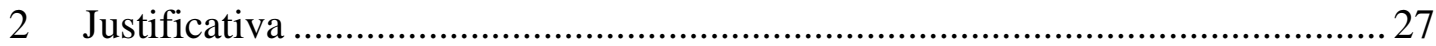

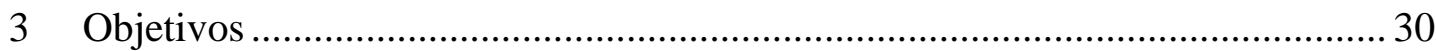

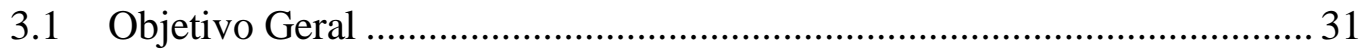

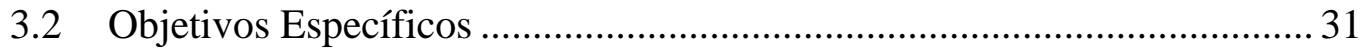

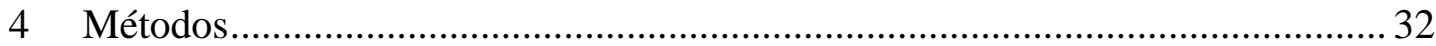

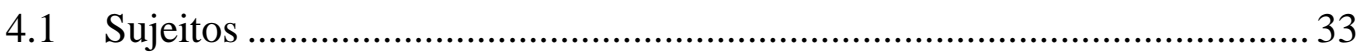

4.1.1 Critérios de inclusão ….............................................................. 33

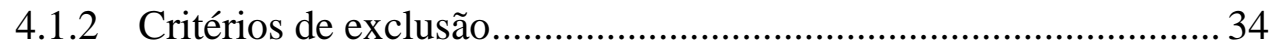




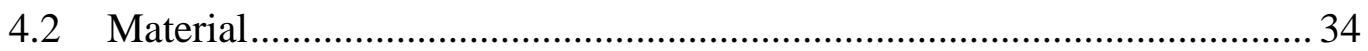

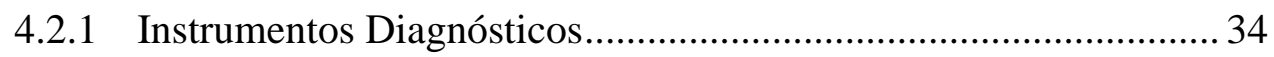

4.2.2 Instrumentos de Avaliação das Funções Corticais Superiores ...... 35

4.2.3 Escalas de avaliação de sintomas ............................................... 37

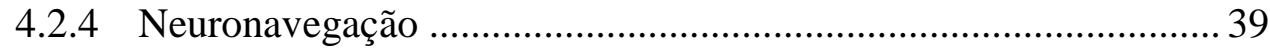

4.2.5 Estimulação Magnética Transcraniana ........................................... 39

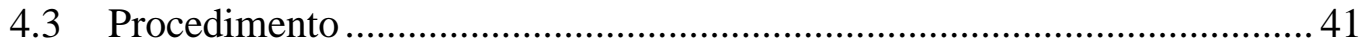

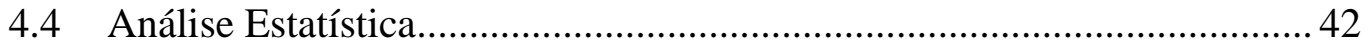

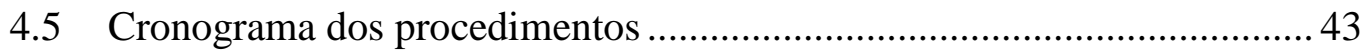

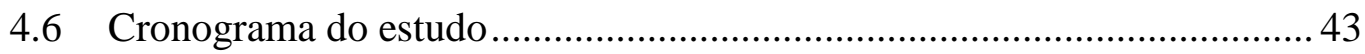

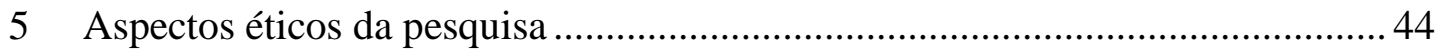

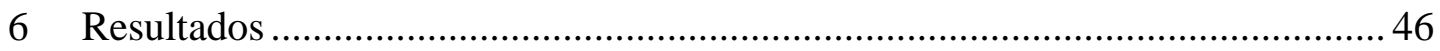

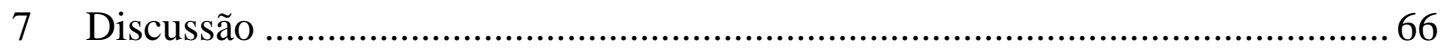

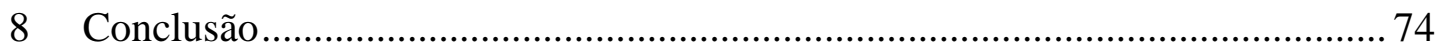

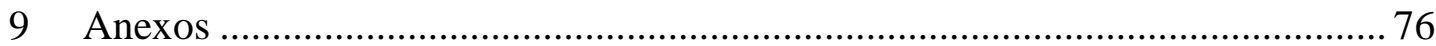

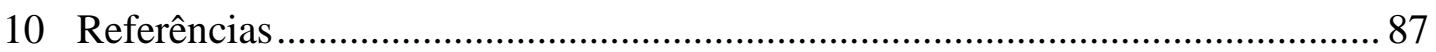




\section{LISTA DE SIGLAS}

CPFVL - Córtex pré frontal Ventro Lateral;

WSCT - Wisconsin Sort Card Test;

YBOCS - Escala de Pensamentos Obsessivos e Comportamentos compulsivos de Yale Brown;

RBS-r - Escala de Comportamento Repetitivos;

CID - Classificação Internacional das Doenças;

APA - American Psychiatry Association;

DSM - Diagnostic and Statistical Manual;

DTI - Diffusion Tensor Imaging;

GABA - Ácido Gama Amino Butírico;

ADI-R - Autism Diagnóstic Interview-revised;

DCCST - Dimensional Change Card Sort Task;

EMT - Estimulação Magnética Transcraniana;

EMTr - Estimulação Magnética Transcraniana de repetição;

TMS - Trascranial Magnetic Stimulation;

LM - Limiar Motor;

LTP - Potencial de Longa Duração;

OMS - Organização Mundial de Saúde;

KSADS - Kiddie Schedule for Affective and Schizophrenia for School Aged Children Childhood;

WISC - Escala de Inteligência Wechler para Crianças;

QI - Coeficiente Intelectual;

EEG - Eletroencefalograma;

RM - Ressonância Magnética;

TCLE - Termo de Consentimento Livre e Escleracido; 


\section{LISTA DE TABELAS}

Tabela 1 - Frequências das Idades dos Sujeitos

Tabela 2 - Frequência dos Coeficientes de Inteligência (QI) pelo WISC III......... 48

Tabela 3 - Coeficiente de Inteligência de Execução (QIe) pelo WISC III ............. 48

Tabela 4 - Coeficiente de Inteligência Verbal (QIv) pelo WISC III ...................... 49

Tabela 5 - Frequência da escolaridade entre os sujeitos ..................................... 49

Tabela 6 - Frequência do nível socioeconômicos dos sujeitos .............................. 50

Tabela 7 - Frequência por diagnóstico ................................................................ 50

Tabela 8 - Frequência das Idades de Início do desenvolvimento da linguagem nos sujeitos

Tabela 9 - Frequência das medicações usadas pelos pacientes durante o protocolo de EMT.

Tabela 10 - Análise da estatística dos Descritores

Tabela 11 - Correlação entre as Variações: Total de Erros e a Formação de Nível Conceitual no WSCT e Idade de Início do desenvolvimento da Linguagem

Tabela 12 - Correlação entre a variação das variáveis: RBS total, YBOCS Compulsões Total, Respostas Perseverativas no WSCT e Erros Perseverativos no WSCT.

Tabela 13 - Correlação entre a variação das variáveis: Total de Erros no WSCT e Formação de Nível Conceitual.

Tabela 14 - Correlação entre o QI, QIe e QIv e as variações entre as variáveis: RBS Sub Escala 2, 3 e 6 


\section{LISTA DE GRÁFICOS}

Gráfico 1 - Análise qualitativa da comparação do Escore Total de Compulsões pelo YBOCS antes e depois do procedimento de EMT

Gráfico 2 - Análise qualitativa da comparação das medianas do Escore Total de Compulsões pelo YBOCS nos três tempos após triagem

Gráfico 3 - Análise das Médias das Sub Escalas do YBOCS nos três tempos 58

Gráfico 4- Análise qualitativa da comparação do Apanhado Geral dos Escores do RBS antes e depois do procedimento de EMT

Gráfico 5 - Análise qualitativa da comparação das medianas do Apanhado Geral dos Escores do RBS nos três tempos após triagem

Gráfico 6 - Análise das Médias das entre às classes de CRR nos três tempos após triagem

Gráfico 7 - Análise qualitativa da comparação do Total de Erros no WSCT antes e depois do procedimento de EMT

Gráfico 8 - Análise qualitativa da comparação das medianas do Total de Erros no WSCT nos quatro tempos

Gráfico 9 - Análise qualitativa da comparação das Respostas Perseverativas no WSCT antes e depois do procedimento de EMT

Gráfico 10 - Análise qualitativa da comparação das medianas Respostas Perseverativas no WSCT antes e depois do procedimento de EMT

Gráfico 11 - Análise qualitativa da comparação dos Erros Perseverativos no WSCT antes e depois do procedimento de EMT

Gráfico 12 - Análise qualitativa da comparação das medianas dos Erros Perseverativos no WSCT antes e depois do procedimento de EMT.

Gráfico 13 - Análise qualitativa da comparação dos Erros Não Perseverativos no WSCT antes e depois do procedimento de EMT 
Gráfico 14 - Análise qualitativa da comparação das medianas dos Erros Não Perseverativos no WSCT antes e depois do procedimento de EMT

Gráfico 15 - Análise qualitativa da comparação da formação do Nível Conceitual no WSCT antes e depois do procedimento de EMT

Gráfico 16 - Análise qualitativa da comparação das médias da formação de Nível Conceitual no WSCT antes e depois do procedimento de EMT

Gráfico 17 - Análise qualitativa da comparação dos tempos totais para realizar o STROOP test antes e depois do procedimento de EMT

Gráfico 18 - Análise qualitativa da comparação das medianas dos Tempos Totais do STROOP test nos três tempos após triagem (Cent. Seg.) .... 62

Gráfico 19 - Diferença entre Autistas e Síndrome de Asperger às mudanças ocorridas na Formação de Nível Conceitual no WSCT

Gráfico 20 - Diferenças entre Autistas e Síndrome de Asperger às mudanças ocorridas no Total de Erros no WSCT 


\section{RESUMO}

Abuajdi C. Estimulação Magnética Transcraniana em indivíduos com Autismo [dissertação]. São Paulo: Faculdade de Medicina, Universidade de São Paulo; 2013. $107 \mathrm{p}$.

INTRODUÇÃO: O Transtorno do Espectro Autista tem incidência precoce e causas genéticas e ambientais multifatoriais. Gera disfunção no desenvolvimento da linguagem e da sociabilidade e um padrão de comportamento restrito e repetitivo. A formação e o desenvolvimento do sistema nervoso são afetados provocando impacto na arquitetura tecidual, desequilíbrio funcional entre os sistemas excitatórios e inibitórios, além de problemas na conectividade e consistência das redes neurais. $\mathrm{O}$ tratamento baseia-se em estimulação multiprofissional precoce e no uso de medicamentos que interferem na sintomatologia impactante do cotidiano. Os comportamentos restritos e repetitivos marcam o perfil funcional do paciente com Transtorno do Espectro Autista e podem interferir diretamente no desenvolvimento da linguagem e na sociabilidade. A mudança do espectro comportamental em razão do amadurecimento cognitivo não impede o desequilíbrio funcional nas atividades da vida diária. Existem indícios de que a função da flexibilidade cognitiva somada à capacidade para gerar novos conceitos e à velocidade de processamento das informações estão afetadas nesses pacientes e podem representar a base fisiopatológica dos Comportamentos Restritos e Repetitivos e suas repercussões no desenvolvimento desses indivíduos. O presente estudo visa avaliar os efeitos da facilitação da transmissão dos impulsos nervosos na função da flexibilidade cognitiva e no comportamento restrito e repetitivo dos pacientes com o diagnóstico de Transtorno do Espectro Autista de alto funcionamento através da Estimulação Magnética Transcraniana de pulsos pareados no Córtex Pré Frontal Ventro Lateral (CPFVL) direito em sua porção antero inferior. MÉTODOS: Trata-se de um estudo experimental com procedimento sistematizado e intervencional realizado com 11 pacientes de 9 a 17 anos, pareados por um perfil cognitivo dentro dos limites da normalidade, que foram submetidos ao protocolo de estimulação com a técnica de "Theta Burst" em CPFVL antero inferior à direita em 15 sessões divididas em três semanas. Os pacientes foram testados antes e depois do procedimento. A avaliação da flexibilidade cognitiva, da capacidade de formação de novos conceitos e do tempo cognitivo foram realizada através dos testes Wisconsin Sort Card Test (WSCT) e STROOP, aplicados aos pacientes. Os Comportamentos Restritos e Repetitivos foram avaliados pelos instrumentos Repetitive Behavior Scale - Revised (RBS-r) e Escala de Pensamentos Obsessivos e Comportamentos Compulsivos de Yale Brown (YBOCS) por meio de questionários aplicados aos pais e cuidadores desses pacientes. RESULTADOS: Encontraram-se evidências de mudanças no padrão de inflexibilidade cognitiva, representada pelo WSCT, nos itens Erros Perserverativos $(p=0,028)$ e na Formação de Nível Conceitual $(p=0,022)$. A alteração demonstrada 
pela Formação de Nível Conceitual pelo WSCT e pelo Total de Tempo para realizar o STROOP test $(p=0,001)$ representam mudança na velocidade de processamento de informações. Constatou-se melhora do Comportamento Restrito e Repetitivo tanto pelo RBS-r $(p=0,002)$ quanto no YBOCS Total de Compulsões $(p=0,02)$. Todas as classes mostraram mudanças significativas: Ordem Inferior $(p=0,05)$, Ordem superior $(p=0,028)$ e Insistência na Mesmice $(p=0,014)$. Houve correlação entre as curvas que representam as mudanças ocorridas no RBS-r e na flexibilidade cognitiva, representada pelo item Respostas Perseverativas $(r=0,049)$. Por se tratar de um piloto, o presente estudo permite o aprofundamento das pesquisas que relacionam esta forma de intervenção descrita ao tratamento do Comportamento Restrito e Repetitivo em pacientes com Transtorno do Espectro Autista.

Palavras chave: 1.Trantorno do Espectro Autista 2.Comportamento Restrito e Repetitivo 3.Estimulação Magnética Transcraniana 4.Theta Burst 


\begin{abstract}
Abuajdi C. Transcranial Magnetic Stimulation on Autistic Individuals [dissertation]. São Paulo: "Faculdade de Medicina, Universidade de São Paulo"; 2013. 107p.
\end{abstract}

INTRODUTION: The Autism Spectrum Disorder has an early incidence. It has genetic and environment multifactorial causes. Patients present language and social development disability and restricted and repetitive behavior. The maturation and development of the nervous system are damaged. Hence there is a disruption on the tissue architecture, functional imbalance between excitatory and inhibitory systems and connectivity and consistency of neural networks issues. The treatment is grounded on premature multiprofessional stimulation to improve cognition and the medication for mood instability, sleep problems, anxiety, hyperactivity and attention problems. The Restricted and Repetitive Behavior marks the functional profile of the Autism Spectrum Disorder and can hinder the communication and sociability development. The behavior changes with the cognitive maturation but does not prevent from the functional imbalance in daily activities. Evidence revel that the cognitive inflexibility added to the impairment to form new concepts and cognitive tempo can reflect the pathophysiology of these behaviors and its impact on development. The current study aims to valuate changes on cognitive flexibility and restricted and repetitive behavior after the facilitation of impulses through paired pulse Trascranial Magnetic Stimulation (EMT) on right anterior inferior Ventro Lateral Pre Frontal Cortex (VLPFC) in high function Autism Spectrum Disorder individuals. METHODS: It is an experimental study with systemic interventional procedure. Eleven subjects with nine to seventeen years old paired by normal cognitive profile were submitted to the protocol of Theta Burst stimulation on right anterior inferior VLPFC with fifteen sessions divided into three weeks. Subjects were tested before and after the procedure. They were tested for cognitive inflexibility, the ability to form new concepts and the cognitive tempo by the Wisconsin Sort Card (WSCT) test and STROOP test. The restricted and repetitive behaviors were evaluated by Restricted and Repetitive Behavior Scale revised (RBSr) and Yale Brown Obsessive and Compulsive Scale applied for parents. RESULTS: Evidence of changes on cognitive inflexibility pattern were found items Perseverative Errors $(p=0,028)$ and Conceptual level Response $(p=0,022)$ of the WSCT test. Information processing speed changes were established by the Conceptual level Response of the WSCT and the Total Time to Finish the STROOP test $(p=0,001)$. Improvement on restricted and repetitive behavior were found by changes on total score of RBS-r $(p=0,002)$ and by YBOCS Total of Compulsions $(p=0,02)$. There were changes on all aspects of the repetitive behaviors: Low-Order behavior $(p=0,05)$, High-Order behavior $(p=0,028)$ and Sameness behavior $(0,014)$. Correlation were found between changing curves of cognitive inflexibility represented by Perseverative Response and total score of RBS-r $(r=0,049)$. Since this 
is a pilot study, our data allows us to suggest that EMT-pp can be efficient for treating restricted and repetitive behavior on Autism Spectrum Disorder. Further controlled studies will be conducted to confirm this hypothesis.

Descriptors: 1.Autism Spectrum Disorder 2.Restrited and Repetitive Behavior 3.Transcranial Magnetic Stimulaction 4.Theta Burst 
1 Introdução 


\subsection{Transtorno do Espectro Autista}

\subsubsection{Aspectos Gerais}

Há 70 anos, em 1943 Léo Kanner, psiquiatra austríaco, professor da John Hopkins University e um dos membros fundadores do Journal of Autism in Childhood Schizophrenia, publicou "Autistic disturbances of affective contact" na revista "Nervous Child Journal" (Kanner M., 1943). Foram descritas as principais características do Autismo e as diferenças para as outras patologias estudadas pela psiquiatria, em particular, a esquizofrenia e a deficiência mental.

Apesar de descrito em 1943, o diagnóstico de Autismo apenas foi referendado na série diagnóstica da Organização Mundial de Saúde em 1979, surgindo pela primeira vez, na Classificação Internacional das Doenças (CID) em sua nona versão, classificado entre os transtornos psicóticos (Kramer M., 1979).

A American Psychiatric Association (APA), em 1980, incluiu em sua terceira edição do Diagnostic and Statistical Manual (DSM), a classificação de "Autismo Infantil". O termo "Infantil" foi retirado dos manuais seguintes, tanto na terceira versão revisada quanto na quarta, por acreditar-se que o transtorno não era algo específico da infância (American Psychiatric Association, 1980; American Psychiatry Association 1987).

Em 1993, na CID 10, o Autismo passou a ser classificado entre os Transtornos Invasivos do Desenvolvimento, juntamente com o Transtorno Desintegrativo na Infância, Síndrome de Rett, Síndrome de Asperger e Autismo Atípico (Organização Mundial de Saúde, 1993).

Para o diagnóstico, não devem ser levados em conta os aspectos biológicos da síndrome, e sim, apenas, seus aspectos fenomenológicos. Dessa maneira, o Autismo pode associar-se a uma série de patologias com mecanismos fisiopatológicos distintos. Divide-se em primário, quando não há outras causas etiológicas que justifiquem o comportamento em questão e secundário, no caso de existir uma ou 
mais patologias gerando a síndrome. Dessa forma, pode estar associado com relação de causa e efeito ou como simplesmente comorbidade às síndromes genéticas, neurológias e metabólicas (Rutter M., Schopler E., 1987).

Até o final de 2012 o diagnóstico deveria ser atribuído somente após 36 meses de idade (American Psychiatric Association, 1994; Organização Mundial de Saúde, 1993). A partir de 2013, o DSM-5, o diagnóstico pode ser dado a partir dos 24 meses de idade. Outra mudança importante foi à junção de todos os diagnósticos para um único definido como Transtorno do Espectro Autista. Esse fato tem gerado muita polêmica, principalmente entre as comunidades de familiares, cuidadores e pacientes com Síndrome de Asperger. Existe sim dúvida se o quadro em questão necessitaria de um olhar crítico e um tratamento mais específico. Inúmeras linhas de pesquisa tentam comprovar se os quadros diferem quanto a suas bases fisiopatológicas e, portanto se não seriam transtornos diferentes (Frith U., 1991). Entretanto, as controvérsias provavelmente tem por base o foco teórico nosológico em que a Síndrome de Asperger foi criada (Sharma S. et al., 2011). A justificativa dos especialistas para tal alteração no modelo classificatório diagnóstico está na facilitação da criação de modelos baseados no desenvolvimento molecular e da genômica que norteiam as bases fisiopatológicas relacionadas ao espectro em recentes estudos (Frazier T.W. et al., 2012).

A manifestação dos primeiros sintomas pode ser evidenciada mesmo nos primeiros meses de vida e estão relacionadas a movimentos irregulares de membros, hipersensibilidade a luz e dificuldade no contato afetivo com mãe. Sintomas secundários como a dificuldade em exercer uma boa qualidade do padrão de sono e ou atrasos em outras áreas do desenvolvimento podem estar presentes (Karmel B.Z., 2010).

As alterações na interação social também podem ser observadas desde o início. Em alguns casos, o contato 'olho a olho' já se apresenta anormal antes do final do primeiro ano de vida (Mirenda P.L., Donnellan A.M., Yoder D.E., 1983). Muitas crianças mantêm um contato breve ou olham de canto de olho, não demonstram postura antecipatória ao serem pegos pelos pais, podendo resistir ao toque ou ao abraço. Dificuldades em se moldar ao corpo, quando no colo, são observadas precocemente. Algumas crianças que, posteriormente, receberam o diagnóstico, já demonstravam falta de iniciativa, de curiosidade ou comportamento exploratório, ainda quando 'bebês’ (Tuchman R., Rapin I., 2006). 
Falhar em desenvolver a linguagem oral no tempo correto é o sintoma mais relacionado à procura de profissionais de saúde para diagnóstico. No entanto, dificuldades na comunicação são evidentes mesmo antes do período de aquisição da linguagem verbal, mas passam, na maioria das vezes, despercebidos pelos pais (Hudry K. et al., 2013). Apresentam dificuldade, atraso ou ausência total no desenvolvimento da linguagem verbal. Mesmo os pacientes verbais, apresentam dificuldades marcantes em iniciar ou sustentar diálogos e, muitas vezes, apesar de se utilizarem da fala, tem dificuldade em manter a conversa como uma troca. $\mathrm{O}$ uso restrito e estereotipado da linguagem é bem descrito na literatura (Tuchman R., Rapin I., 2006). Ainda podem apresentar outros sintomas como: ecolalia imediata ou tardia, inversão pronominal, linguagem idiossincrática, linguagem metafórica e a invariabilidade do ritmo e tonalidade da linguagem verbal.

Ainda no âmbito da comunicação podem demonstrar sérios problemas na compreensão, utilização da mímica e gestualidade. Ocorrem formas atípicas de processamento dos sons e outros estímulos gerados pelo ambiente desde fases muito precoces do desenvolvimento. Esse fato pode ser a causa de respostas tão discrepantes quanto ao tempo e a intensidade (Samson F. et al., 2011).

Quanto às alterações comportamentais, um repertório restrito e pouco criativo de interesses e atividades ocorre nos indivíduos com o transtorno, principalmente, em seu foco e intensidade. Apresentam insistência na 'mesmice', mostrada em comportamentos inflexíveis e preocupações excessivas com rotinas e rituais que podem ou não estar relacionadas a atividades funcionais da vida diária. Nesses casos, mudanças no ambiente podem causar episódios de agitação psicomotora e agressividade. Algumas, mínimas, insignificantes aos nossos olhos, podem causar quadros mais severos de agitação. Dessa forma, as reações emocionais podem ser inesperadas e inadequadas, tanto pelo exagero, quanto para a indiferença (Turner M., 1999).

Movimentos corporais estereotipados são comuns. Apresentam-se sob a forma de "flapping" (movimentos repetitivos dos braços e/ou mãos ao lado da cabeça), balanceio da cabeça, movimentos com os dedos, saltos e rodopios. Esses movimentos costumam prevalecer, principalmente, entre os mais jovens e os que têm um funcionamento global mais comprometido. À medida que a idade avança e o padrão cognitivo vai evoluindo, os comportamentos restritos e repetitivos vão 
mudando. Chamam-se de comportamentos de Ordem Inferior os imaturos e os de Ordem Superior os maduros (Esbensen A.J. et al., 2009).

Indivíduos com Transtorno do Espectro Autista mostram, em geral, uma desigualdade evolutiva para as diferentes funções corticais superiores. Algumas podem estar comprometidas e outras normais ou até superando as expectativas para a idade (Happé F., Frith U., 1996). As funções relacionadas à memória e a atenção são as mais controvérsias.

Outros sintomas comportamentais associados à síndrome incluem impulsividade, dificuldade no controle inibitório, dificuldade no direcionamento, intolerância a frustrações, comportamentos agressivos com acessos de auto e hetero agressividade e agitação psicomotora. Comumente, os pacientes têm respostas extremas aos estímulos sensoriais, tais como hipersensibilidade a luz, som, toque, e fascinação por certos estímulos auditivos ou visuais (Happé F., Frith U., 1996).

Dessa forma, por se tratar de um transtorno tão complexo, a gravidade dos sintomas, presença de comorbidades, idade do diagnóstico, do início do desenvolvimento da fala, do tratamento, nível intelectual e acadêmico podem afetar o prognóstico (Rutter M., Hersov L., 1992). Contrapondo os quadros mais severos que possuem um alto grau de dependência e isolamento, alguns pacientes têm sintomas muito leves. Por vezes, chegam a constituir família, serem bem sucedidos profissionalmente e apresentar habilidades não presentes em pessoas com desenvolvimento típico. A ciência tem estudado esses casos com o objetivo de entender melhor a fisiopatologia. As evidências mostram que as variáveis funcionais da infância são preditores da fase adulta (Farley M.A., et al. 2009).

\subsubsection{Epidemiologia}

Existem inúmeras dificuldades para se estudar a epidemiologia dos quadros relacionados ao Transtorno do Espetro Autista. A variabilidade e a ausência de marcadores biológicos levam a prática diagnóstica a incluir métodos caros, de difícil treinamento e que sofreram inúmeras mudanças nas últimas décadas. A consistência histórica dos dados analisados apresenta-se fraca apesar dos primeiros estudos de prevalência já estarem completando 50 anos. Por esse motivo, a partir de 2008 
organizações, como o CDC (Center for Disease Control and Prevention) nos Estados Unidos da América, Autism Speaks, organização não governamental e o Movimento pela Saúde Mental Global ligado a Organização mundial de Saúde criaram métodos para unificar os padrões de avaliação e a captação dos dados e treinamento de equipes com o intuito de fortalecer e validar os bancos de dados (Patel et al., 2008; WHO, 2008).

Mesmo com todas essas dificuldades, podemos inferir que tanto a incidência, proporção de casos novos diagnosticados, quanto a prevalência, proporção de casos na população, do Transtorno do Espectro Autista vem aumentando desde os primeiros trabalhos publicados no final da década de 60 até os dias atuais (Elsabbagh M. et al., 2012). Até a 1986 os estudos apresentaram uma prevalência que não ultrapassava os 10/10.000 casos. Dez anos depois, 1996 as prevalências máximas chegavam a 30/10.000 casos. A partir da inclusão do conceito dos Transtornos Invasivos do Desenvolvimento no ano 2000, incluindo todos os quadros que envolvem o Espectro Autista, alguns estudos chegaram a mostrar uma prevalência de até 280/10.000 casos (Elsabbagh M. et al., 2012).

As causas para esse aumento são diversas. Por um lado existiram mudanças nos critérios, na idade de diagnóstico e na formação de equipes mais técnicas para a identificação dos pacientes (Honda H. 1996; Wong V.C, Hui S.L., 2008). Por outro, existem fortes evidências mostrando que fatores causais estão mais impactantes. Estudo publicado pelo CDC em 2002 formalizou essa perspectiva encontrando diferenças na prevalência entre os 14 Estados avaliados com o mesmo critério. Foram analisadas 408.000 crianças de oito anos de idade e a prevalência variou de 33/10.000 no Alabama a 106/10.000 em New Jersey. A variabilidade em diferentes localizações podem representar diferentes exposições aos fatores de risco (CDC, 2002 - 2007).

Dois são os dados mais concisos apresentados pela literatura. O Transtorno do Espectro Autista tem uma prevalência 4.2 vezes maior no gênero masculino do que no feminino. E a média da prevalência de todas as formas diagnósticas incluídas dentro de espectro do Autismo para os trabalhos que foram publicados após o ano 2000 até 2009 foi de 67,3/10.000 (Fombonne E., 2009).

No Brasil existe um estudo piloto que foi publicado em 2011. Mostra uma incidência de 0,3\% de Transtorno do Espectro Autista em uma população de 1.470 crianças avaliadas. Apesar do baixo número de sujeitos avaliados para um estudo 
epidemiológico, a prevalência encontrada foi abaixo da média dos outros trabalhos publicados recentemente (Paula C.S. et al., 2011). Novos estudos devem ser feitos em diferentes regiões que possam analisar tanto populações rurais, quanto urbanas. As dimensões continentais do Brasil podem gerar dados muito esclarecedores para apresentar e confirmar padrões etiológicos discutidos pela literatura.

\subsubsection{Etiopatogenia}

O Transtorno do Espectro Autista apresenta causas mutlifatoriais. A etiopatogenia pode ser dividida em duas linhas gerais: genéticas e ambientais. Ambas se inter-relacionam de forma complexa desde fases muito precoces do desenvolvimento gerando fenótipos individuais totalmente diferenciados (Persico A.M., Bourgeron T., 2006). Os novos conceitos epigenéticos que norteiam o conhecimento sobre o amadurecer do sistema nervoso e suas variações patológicas são essenciais para o entendimento do transtorno. Interferências tanto no "timing" de início da transcrição, no tempo em que cada gene permanece produzindo determinada proteína ou ainda a intensidade com que essas substâncias são produzidas podem gerar interferências em toda uma cadeia de desenvolvimento.

Uma porcentagem pequena dos pacientes apresenta uma alteração gênica específica gerando o comportamento autístico, como é o caso da Síndrome de Down, Síndrome do X-Fragil dentre outras. Esses pacientes possuem o diagnóstico de Autismo secundário. Entretanto, a grande maioria dos pacientes apresentam alterações genéticas múltiplas e diferentes e formam uma classe diagnóstica específica denominada primária ou idiopática.

Os indivíduos acometidos podem apresentar problemas na genética da formação de manutenção das conexões sinápticas dos neurônios. As bases da neuroliguinas (Jamain S. et al., 2003), das neuroxinas (Feng J. et al., 2006) e das moléculas SHANK, associadas tanto às sinapses excitatórias quanto inibitórias podem estar afetadas (Durand C.M. et al., 2007). Particularmente, essas mutações gera dificuldades na formação de potenciais de longo prazo e portanto, memória e aprendizado. Recentemente, em estudos de modelos animais a proteína RICH2 mostrou-se aumentada nas espinhas dendríticas. Apresentam relação direta com os 
receptores de Glutamato Alfa-Amino-3-Hydroxi-5-Metil-4-Isoxazolepropionico (AMPA). O par SHANK3-RICH2 está diretamente ligado à formação de sinapses e potenciais de longo prazo e devem ter relação direta com as dificuldades de aprendizado e memória em pacientes com o Transtorno do Espectro Autista (Raynaud F. et al., 2013).

PTEN é uma fosfatase lipídica e proteica mais conhecida como responsável por inibir a sobrevivência celular, suprimindo a formação de tumores. No hipocampo essas proteínas estão alocadas nas sinapses, tanto nas posições pré, quanto pós estrategicamente para regular a plasticidade sináptica. Mutações nos grupos de genes que regulam a produção das proteínas PTEN em regiões específicas cerebrais estão associadas à macrocefalia e a problemas de socialização nos pacientes com o Transtorno do Espectro Autista. Essas proteínas regulam negativamente a via fosfatidilinositol 3-quinase (PI3K) envolvida na regulação do ciclo celular e modula a proliferação celular e sua sobrevivência (Butler M.G. et al., 2005). A marca característica é progressiva macrocefalia do giro denteado, que em última análise provoca a compressão de células piramidais da camada CA1 do Hipocampo. Os estudos animais que simulam essas mutações mostram que essas alterações sinápticas hipocampais que modulam as células excitatórias do córtex se correlacionam com as alterações comportamentais, problemas cognitivos e déficits sociais (Takeuchi K. et al., 2013).

O desenvolvimento do sistema GABAérgico, que modula inibição, está diretamente ligado ao equilíbrio entre o sistema excitatório modulado pelo Glutamato e o inibitório. Os genes responsáveis pelos produtos proteicos MET tirosina quinase são responsáveis pela migração dos interneurônos GABAérgicos. Mutações ocorridas nessa classe de genes estão associadas a famílias de pacientes dentro do Espectro Autista (Campbell D.B. et al., 2006).

Em contrapartida, os fatores de crescimento de fibroblasto (FGF) em todos os seus subtipos regulam a quantidade de neurônios excitatórios e o crescimento do córtex cerebral. A desregulação na quantidade e no tempo correto da expressão dos genes responsáveis por cada subtipo de FGF pode ser responsável pela alteração no crescimento cerebral e alterações na modulação cortical e conectividade (Vaccarino F.L. et al., 2010). 
Os estressores relacionados ao ambiente em todas as suas formas podem se relacionar diretamente com o Transtorno do Espectro (Casanova M.F., 2007; Shanen M.C., 2006). Particularmente, alguns dados mostram que o segundo e terceiro trimestre da gestação estão relacionados à maior vulnerabilidade do desenvolvimento do sistema nervoso central (Badawi N. et al., 2006).

A prematuridade é fator etiológico ambiental mais relevante. Quanto menor a idade gestacional no parto maior o risco de se desenvolver o quadro do Transtorno do Espectro Autista (Moster D., Lie R.T., Markestad T., 2008). Outras complicações obstétricas como a hipóxia no intraparto em suas inúmeras causas: sangramento durante a gravidez, hipotensão maternal, parto cesárea, estresse fetal e baixo apgar estão ligados a um aumento da incidência (Bilder D. et al. 2009; Brimacombe M., 2007).

Além da lesão tecidual direta promovida por situação de privação de oxigênio, o feto pode sofrer influências do sistema imunológico da mãe. Estados de instabilidade podem promover reações cruzadas em que a defesa materna passa a reconhecer proteínas fetais como agressoras (Badavi D. et al., 2006). Existem evidências que as respostas imunológicas das mães, que estão sob estresse, às proteínas responsáveis pelo desenvolvimento do cérebro dos fetos têm correlação com a incidência de Autismo (Braunschweig D. et al., 2013). Essa linha de raciocínio vem a corroborar com o fato de quadros depressivos em mães, principalmente em uso de antidepressivos durante a gestação poder aumentar o risco do quadro nos filhos nascidos (Rai D. et al., 2013; Angelidou A. et al. 2012).

Mesmo antes da fecundação, a idade e o estilo de vida dos pais podem favorecer alterações genéticas nos gametas, principalmente dos homens que os renovam semanalmente. A idade da paternidade foi recentemente relacionada ao aumento dessas mutações e assim à maior incidência de Autismo e Esquizofrenia (Kong A. et al., 2012).

Dessa forma, podemos dizer que muito estamos aprendendo sobre o desenvolvimento do sistema nervoso, sua genética e relação com os sistemas endócrino, metabólico e imunológico e as repercussões sobre o impacto no desequilíbrio precoce desses sistemas. O Transtorno do Espectro Autista segue esse raciocínio epigenético em que fatores ambientais genéticos se associam de forma complexa (Shanen M.C., 2006). 


\subsubsection{Fisiopatologia}

Os conceitos fisiopatológicos do Transtorno do Espectro Autista vêm se aprimorando. Desde longa data, descobertas genéticas, morfológicas e funcionais relacionadas ao desenvolvimento do sistema nervoso central vêm inserindo horizontes mais amplos que mudam o entendimento do transtorno (Gilberg C., Coleman C., 1992).

Estudos histopatológicos em cérebros pós mortem mostram alterações displásicas que ocorrem no tecido cerebral tendo como afecção a neurogênese e a migração neuronal (Wegiel J. et al., 2010). O impacto na arquitetura histológica do córtex cerebral está mais concentrado em regiões específicas que se correlacionam com a sistemática funcional da síndrome. Na maioria dos casos, esse contexto gera peculiaridades disfuncionais tanto no córtex quanto na substância branca. As regiões cerebrais que apresentam correlações importantes entre os achados morfológicos e histopatológicos são: o córtex frontal e pré frontal, temporal, amigdala, giro cingulado anterior e cerebelo (Schumann C.M., Nordahl C.W., 2011; Rojas D.C. et al., 2006).

A arquitetura do córtex cerebral normal tem um padrão peculiar na disposição de suas células denominado: Sistema de Minicolunas. Cada uma delas representa as menores unidades corticais de processamento de informações (Montecastle V.B. 1997). Os neurônios recém formados migram de maneira centrifuga das regiões germinativas. Após a neurogênese se posicionam simetricamente em colunas que se orientam paralelamente no córtex cerebral desde a membrana basal até a superfície. Essas colunas celulares trabalham como uma unidade funcional e comunicam-se com as adjacentes. Produzem, basicamente, estímulos excitatórios modulados por Glutamato. Sua inibição se dá através de interneurônios moduladas principalmente por GABA com o intuito de modular excitações inapropriadas (Peters A, Cifuentes JM, Sethares C, 1997).

Foram encontradas alterações nessa arquitetura cortical nos indivíduos com Transtorno do Espectro Autista. O sistema de minicolunas podem conter corpos celulares com alteração de volume, forma e ainda dispostos de forma irregular, descaracterizando o alinhamento típico das mesmas. Estudos demonstram que algumas regiões cerebrais podem ser mais afetadas do que outras e por isso determinam um padrão que pode variar de acordo com o quadro clínico (Casanova M.F. et al.,2006, 2010). 
Além das alterações ocorridas na formação, migração e disposição neuronal existem fortes evidências de que a eficiência das podas neuronais que ocorrem ao longo do desenvolvimento podem estar afetadas nos pacientes dentro do Espectro Autista (MacCaffery P., Deutsch C.K., 2005). As podas neuronais tem a função de selecionar os neurônios que estariam mais aptos durante o desenvolvimento. Falhas nesse mecanismo podem gerar atrasos no desenvolvimento ou regressões de comportamentos já adquiridos como observado em parte dos pacientes nos primeiros anos de vida (Thomas M.S., Knowland V.C., Karmiloff-Smith A., 2011).

A representação das alterações histopatológicas estruturais gera um cérebro com desenvolvimento morfológico diferenciado nos paciente com Transtorno do Espectro Autista. As evidências variam de acordo com a capacidade funcional do indivíduo.

Após o nascimento, evidências sugerem que não há nenhuma alteração nos volumes de substâncias cinzenta e branca (Gilberg C., De Souza L., 2002). Começam a partir do quarto mês e atingem seu ápice aos 12 meses (Courchesne et al., 2003). Após o término do segundo ano, a maior parte delas já ocorreu (Hazlett et al., 2005). $\mathrm{O}$ aumento no volume cerebral total é evidenciado pelo aumento do perímetro cefálico (Lainhart, 2006). Cerca de $20 \%$ das crianças com o Transtorno do Espectro Autista tem macrocefalia com aumento de até 2 desvios padrões da médias perímetros cefálicos (Milles J.H. et al., 2000). Na fase adulta torna-se mais difícil encontrar essas diferenças, principalmente no volume total, podendo ser encontrado aumento na substância cinzenta no hemisfério esquerdo (Hazlett et al., 2006). Provavelmente, os fatores responsáveis pela macrocefalia citados anteriormente não se manifestam com tanta eficiência a partir da adolescência.

A amígdala, região cerebral responsável pela memória afetiva e pelo controle da intensidade das reações, também apresenta peculiaridades de desenvolvimento com aumento de seu volume a partir dos dois anos de idade (Mosconi M.W. et al., 2009; Howard M.A. at., 2000). Essas alterações podem justificar o aumento das reações afetivas apresentadas por um grupo de pacientes. A partir da adolescência o volume da amígdala também passa a ter valores mais próximos da normalidade. Achados funcionais mostram que a antecipação da recompensa, ansiedade gerada por reforços que estão por vir, pode gerar hiperexcitação da amídala, nos pacientes com 
Transtorno do Espectro Autista. Essa tem correlação inversa com o nível cognitivo dos pacientes (Dichter G.S. et al., 2012).

Diferenças nos lobos temporais tem forte relação com a diminuição na velocidade de processamento do reconhecimento das faces (McPartland J. et. al., 2004). Estudos mais recentes mostram que a incapacidade vai mais além. As crianças acometidas têm dificuldade de reconhecer expressões, emoções faciais e estímulos animados abstratos (Boraston Z. et. Al., 2007). O giro fusiforme, principalmente na área facial fusiforme, também se relaciona com o reconhecimento das faces (Hazby J.V. et al., 2000) e tem sua função comprometida em indivíduos que fazem parte do espectro autista (Schultz R.T. et al., 2000; Hubl D. et al., 2003).

Particularmente, as alterações das regiões do sulco temporal superior, giro temporal medial e lóbulo parietal inferior parece estar relacionado com o processamento inadequado do olhar e a detecção das intenções do mesmo (Mosconi M.W. et. al. 2005). As alterações mostradas nas regiões temporais estão diretamente atreladas ao comportamento autístico, principalmente aos relacionados à percepção social. Estudos demonstram que quanto maior o impacto dos sintomas maior o impacto funcional nas regiões superiores dos lobos temporais. (Zilbovicius M. et al., 2006).

Estudos com estimulação auditiva demonstraram menor ativação da rede temporal esquerda no processamento de palavras comparadas a controles pareados por idade (Boddaert, N. et al., 2004). Recentemente, identificou-se a área seletiva da voz, situada na margem superior do sulco temporal superior, sendo responsável pela identidade acústica representativa, "face auditiva” (Bellin P. et al., 2000). Essa região também sofre uma alteração de ativação quando solicitada nos indivíduos com autismo (Gervais, H. et al., 2004).

Outra alteração evidente refere-se à conectividade intrahemisférica e interhemisférica. O corpo caloso, região cerebral que se situa entre os hemisférios e que carrega grande parte das fibras de axônios que cruzam os lados, pode apresentar diminuição no volume global. Os mapas em três dimensões revelaram alterações volumétricas tanto nas regiões anteriores com posteriores dessa região cerebral reforçando a hipóstese (Vidal C.N. et al., 2006).

Com o advento das tratografias realizadas por Diffusion Tensor Imaging (DTI) novas perspectivas a respeito da funcionalidade da comunicação entre os neurônios 
puderam ser mais detalhadamente revistas. A anisotropia fracional é um valor escalonar que reflete a densidade da fibra neuronal, diâmetro do axônio, e a mielinização da substância branca. Os pacientes do espectro Autista mostram um balanço anômalo desse valor (Cheng Y. et al., 2010). As funções corticais complexas que exigem atividades simultâneas de diferentes regiões cerebrais, como por exemplo, a congruência do humor com a situação ambiental, a linguagem, processamento viso espacial, a sociabilidade dentre outras podem estar comprometidas em caso de prejuízo da conectividade. O próprio desenvolvimento da substância branca nos primeiros anos de vida parece ter um formato peculiar. A anisotropia fracional se mostra alterada de forma peculiar em fases muito precoces do desenvolvimento coincidindo com as fases de aparecimento de sintomas considerados importantes por volta do primeiro ano de vida (Wolf J.J. et al., 2012). Esses achados mostram uma base biológica para o agravamento dos sintomas relacionados ao Transtorno do Espectro Autista nessa idade específica em alguns casos.

De uma forma geral pode-se dizer que a dessincronia entre a excitação e a inibição e a dificuldade de conectividade descritos nesse capítulo são os dois focos fisiopatológicos principais do Transtorno do Espectro Autista (Jung H.N. et al., 2013). A incidência precoce desses fatores no desenvolvimento do sistema nervoso gera a maior parte dos prejuízos apresentados pelos pacientes. Portanto devem ser observadas e tratadas desde o início para que o impacto desses fatores seja pormenorizado.

O Córtex Pré Frontal Dorso Lateral tem a função de gerenciar a mudança das atividades corticais dependente da função a ser realizada em determinado momento. A coordenação do desativar e ativar das regiões cerebrais para que a mudança das atividades deve acontecer de forma eficiente e sincrônica. A Existe uma dificuldade nas funções relacionadas às mudanças das atividades corticais mostrada tanto em ressonâncias funcionais (Kennedy D.P. et al., 2006). A mesma dessincronia pode ser evidenciada em testes eletrofisiológicos nas diferentes fases em que as mudanças das funções corticais (Welsh J.P. et al., 2005). 


\subsubsection{Neurobiologia do Comportamento Restrito e Repetitivo}

Os comportamentos Restritos e Repetitivos se referem a uma ampla classe de respostas comportamentais caracterizadas pela repetição, rigidez e inflexibilidade. (Lewis M.H., Bodfish J.W., 2009) Apresentam uma relação intima com as repostas sensoriais atípicas dos pacientes dentro do espectro do Autismo. (Gabriel R. et al., 2008) Podem ser divididos em subtipos segundo classificação proposta por Bodfish no início do século em comportamento estereotipado, auto agressivo, compulsivo, ritualístico, insistência na mesmice e comportamento restrito. (Bodfish J.W. et al.,1999) De um modo geral, tem um padrão de evolução natural durante as diferentes fases da vida. Generalizando, a tendência é de diminuição progressiva com a idade. Pacientes com comprometimento cognitivo tem uma tendência de apresentar sintomas mais graves e de ter uma curva de decréscimo mais amena. (Esbensen A.J. et al., 2009)

Pode-se ainda agrupar esses subtipos em comportamentos de Ordem Inferior, instaladas em indivíduos mais imaturos, com um cérebro em que prevalecem funções mais sensoriais e motoras (movimentos corporais e uso de objetos de forma estereotipada, maneirismos e auto agressividade) e de ordem superior, que possuem um componente cognitivo distinto caracterizado por uma alta adesão a certas regras ou estado mental (compulsões, rituais, insistência na mesmice, interesses restritos). (Lewis M.H., Bodfish J.W., 1998; Tuner M., 1999) Os Interesses Restritos podem ser classificados em uma terceira classe com maior diferenciação cognitiva. (Lam K.S. et al., 2008)

Ao analisarmos os correspondentes anatômicos funcionais, as regiões cerebrais que se relacionam mais diretamente esse padrão de sintomas são o córtex frontal e parietal. A ativação do giro cingulado anterior também tem relação direta, principalmente com a resistência a mudança e a insistência à mesmice. (Rojas D.C. et al., 2006) Ainda, foram analisadas a relação, principalmente da região rostral do giro cingulado, com a análise individual das respostas comportamentais e com o comportamento restrito e repetitivo. Além de consagrar a relação da comunicação, durante os comportamentos restritos e repetitivos, dessa região com o córtex frontal e parietal citados anteriormente. (Thakkar K.N. et al., 2008) 
Como já se suspeitava, essa forma peculiar de se comportar tem correlação com determinadas funções executivas. As funções executivas se definem por uma ampla categoria de processos cognitivos que envolvem o planejamento e a execução de comportamentos flexíveis com objetivos específicos. (O’Hearn K. et al., 2008) Correlacionados ao Comportamento Restrito e Repetitivo estão prejuízos na flexibilidade cognitiva, memória de trabalho no controle inibitório (Lopez B.R. et al., 2005) e na mudança do set cognitivo. (Shafritz K.M., 2008) Outras funções executivas, como o planejamento e a fluência, dentre outras, não apresentam a mesma relação.

Corroborando com essa hipótese, existem evidências de que o processo de desenvolvimento da cognição, mesmo em suas fases mais primitivas já se relacionam com os comportamentos repetitivos de ordem inferior. As estereotipias e compulsões se relacionam mais com as alterações sensoriais. Já os comportamento de ordem superior se relacionam com os déficits cognitivos (Boyd BA et al, 2009) e o controle inibitório. (Mosconi MW et al, 2009) Assim, tanto o impacto funcional quanto o desenvolvimento na cognição estão diretamente ligados ao padrão dos comportamentos restritos e repetitivos.

Testes de desempenho executivo, que provam os indivíduos quanto a sua capacidade em realizar mudanças, como o teste de classificação de cartas de Wisconsin (Heaton R. et al., 2005), mostram-se especificamente alterados proporcionalmente ao impacto dos Comportamentos Restritos e Repetitivos nos pacientes do Espectro Autista de alto funcionamento com coeficiente de inteligência dentro dos padrões de normalidade. (South M. et al., 2007) Por se tratar de um transtorno que pode impactar no desenvolvimento cognitivo, a análise de pacientes que possuem o transtorno sem possuir déficit cognitivo mostra com mais clareza a relação do Autismo com as funções executivas citadas anteriormente.

Além disso, as regiões anatômicas funcionais do sistema nervoso que se relacionam a essas funções executivas correspondem às mesmas descritas anteriormente para os comportamentos restritos e repetitivos. As regiões cerebrais ativadas na execução do teste de cartas Wisconsin, em indivíduos de desenvolvimento dentro dos padrões de normalidade estão relacionas ao córtex pré frontal dorsolateral, ventrolateral e posterior. (Monchi O. et al., 2001) Apesar da ativação acontecer em ambos os hemisférios o lado direito ativaram de maneira mais 
abrangente. Aconteceram ativações também nos gânglios basais e núcleo talâmico mesial. (Mentzel H.J. et al., 1998)

Durante a realização das tarefas, a ativação da região caudal do córtex cingulado anterior está conectada ao Córtex Pré Frontal Dorso Lateral CPFDL e relacionada ao controle atencional e aumento da demanda da memória de trabalho. O córtex cingulado anterior rostral está ligado à ativação temporo parietal bilateral e se relaciona ao trabalho atencional para a detecção de erros. (Lie C.H. et al., 2006) Para a realização da função de mudanças das atividades cognitivas, principalmente no momento da inibição da atividade que deve ser sucedida, o Córtex Pré Frontal Ventro Lateral (CPFVL) mais relacionado ao hemisfério direito parece ter uma papel fundamental. (Aron AR, Robbins TW, Poldrack RA, 2004)

Em última análise, a função de realizar mudanças de atividades cognitivas envolve inúmeras atividades corticais em sincronia. A fisiopatologia descrita em capítulos anteriores, no que tange principalmente o córtex frontal, parietal e giro cingulado e suas conexões estão diretamente relacionadas aos comportamentos restritos e repetitivos. Tratamentos que influenciem na funcionalidade dessas regiões devem modificar essa forma de se comportar e seu impacto no desenvolvimento de outras funções tão importantes para os pacientes com Transtorno do Espectro Autista, como a sociabilidade e a comunicação.

\subsubsection{Tratamento}

Por se tratar de um transtorno relacionado ao desenvolvimento tão complexo, com fenótipos heterogênios e com incidência precoce o tratamento deve ser inserido o mais precoce possível. Tem por base a estimulação precoce com terapias multidisciplinares. Alguns sintomas se mostram de difícil controle e por vezes tem evoluções pouco eficientes, principalmente em quadros severos. (Valkanova V. et al., 2013)

A psicoterapia cognitiva comportamental, fonoterapia, terapia ocupacional, treinamento físico e psicopedagogia devem ser inseridos de acordo com as dificuldades específicas de cada indivíduo o mais precoce possível. Determinadas aquisições no desenvolvimento são mais prováveis de ocorrer na primeira infância e são determinantes 
para outras. O treinamento parental tem se mostrado eficiente para prevenção e manejo dos sintomas, principalmente dos disruptivos. A ideia seria formalizar o conhecimento dos responsáveis sobre as características clínicas de seus filhos e sobre técnicas específicas de abordagens terapêuticas são. (Bearss K. et al., 2013)

Os antipsicóticos atípicos são a primeira linha de tratamento medicamentoso. Os efeitos colaterais estão relacionados a sonolência, problemas metabólicos, principalmente a obesidade e suas consequências. Mesmo assim, a relação eficiência terapêutica e efeitos adversos é positiva, principalmente para o tratamento de irritabilidade. Outros sintomas como agitação e impulsividade respondem positivamente. A risperidona e o aripiprazol estão relacionados a primeira linha de tratamento. A paliperidona e a ziprazidona seguem como escolhas que geram menos efeitos adversos a partir de novas evidências. (Politte L.C., Mcdouque C.J., 2013)

Os problemas relacionados ao sono, tanto para o início, manutenção, quanto à qualidade das fases do mesmo, estão diretamente ligados ao Transtorno do Espectro Autista. (Kotaqal S, Broomall E, 2012) A melatonina tem mostrado boa resposta para a melhora dos parâmetros relacionados ao sono sem efeitos colaterais relevantes. (Rossiqnol DA, Frye RE 2011) Podem ainda ser mais eficientes se o paciente estiver em psicoterapia cognitivo comportamental. (Cortesi F. et al., 2012)

Para o tratamento de sintomas de déficit de atenção e hiperatividade nos pacientes com Transtorno do Espectro Autista os psicoestimulantes, inibidores de receptação de norepinefrina, alfa agonistas podem ser utilizados. Existem grandes restrições ligadas à idade, comorbidades e sintomas típicos dos pacientes com Autismo como ansiedade, irritabilidade, agitação, problemas do sono e história familiar de transtornos afetivos. (Mahajan R. et al., 2012)

Para o tratamento dos comportamentos restritos e repetitivos os antidepressivos mostram evidências desapontadoras. Tanto os inibidores de receptação de serotonina e tricíclicos mostram poucas evidências. A risperidona se mostra mais eficiente para melhorar na intensidade desses sintomas. (Siegel M., 2012) Até o presente momento faltam tratamentos eficientes para a melhora desses sintomas. Mesmo a psicoterapia cognitiva comportamental consegue, pelo amadurecimento do pacientes, uma mudança de padrão sem resolução dos mesmos. Novas técnicas devem ser estudadas. 
De forma geral, os tratamentos existentes para todas as formas do Espectro Autista apresentam evoluções lentas ou geram constantes efeitos adversos que impedem a continuidade. As terapias multiprofissionais prestam a amadurecer habilidades cognitivas específicas prejudicadas pela patologia, entretanto tem evoluções lentas que atrasam a evolução de novas aquisições. Os medicamentos são pouco específicos e geram efeitos colaterais. Novas formas terapêuticas mais eficientes, específicas e menos prejudiciais precisam ser testadas.

\subsection{Estimulação Magnética Transcraniana (EMT)}

\subsubsection{Aspectos Gerais}

Em 1985, Barker AT e outros pesquisadores publicam na revista "The Lancet" o artigo "Non-Invasive Magnetic Stimulation of the Human Motor Córtex". Descrevem pela primeira vez um método de estimulação magnética não invasiva do córtex motor humano e comparam a técnica com a estimulação elétrica. Demonstram que a técnica é de fácil uso, não provoca dor e não necessariamente envolve o contato da bobina com o paciente, o que reduz o desconforto a nível bem tolerável pelo paciente. Um breve estímulo elétrico (com pico de 4000 A após $10 \mu \mathrm{s}$ ) advindo de um capacitor de alta voltagem transforma-se em um campo magnético de 1 a 2 Tesla em forma de cone por meio de uma bobina plana em forma de circular de $100 \mathrm{~mm}$ de diâmetro, coberta por fios de cobre em espiral por toda sua extensão. Quando a bobina é alocada próxima ao córtex motor e acionada, os músculos da mão, pé e braços se movimentavam sem qualquer estresse ou dor. (Barker A.T. et al., 1985)

Seguindo os princípios de Michael Faraday (1291-1867) sobre a indução elétrica através da variação do campo magnético, a EMT é capaz de gerar um potencial de membrana nos neurônios. Os axônios possuem uma grande quantidade de canais iônicos e são ativados, preferencialmente, por pulsos magnéticos de fraca intensidade. Em consequência, são criados pulsos elétricos que seguem o eixo neuronal até os axônios terminais pré-sinápticos, descarregando neurotransmissores. São atingidos tanto neurônios excitatórios, modulados basicamente por glutamato, 
quanto inibitórios, modulados por GABA. Além desse efeito considerado local, ocorrem estímulos neuromoduladores de longa distância do Tálamo e de núcleos de diferentes regiões cerebrais que envolvem os neurotransmissores, acetilcolina, dopamina, serotonina e norpeinefrina, para o córtex estimulado. Assim, a ativação de células piramidais pode ter efeitos difusos sobre alvos pós-sinápticos dessas células e a excitação de axônios terá efeitos antidrômicos (de volta ao longo da árvore dendrítica do axônio) e ortodrômicos (para longe do corpo celular e em direção ao alvo de projeção do neurônio). A resposta funcional do estímulo eletromagnético tem relação direta com a região estimulada. Estímulos promovidos no córtex motor terão respostas motoras, na área de Broca, respostas na expressão verbal e assim por diante. (Huerta PT, Volpe BT, 2009)

A EMT e a Eletroconvulsoterapia (ECT) utilizam princípios semelhantes para promover despolarização neuronal no córtex cerebral. Entretanto, a baixa condutância elétrica dos tecidos adjacentes, como cabelo, pelo, ossos e meninge, exigem que correntes de forte intensidade sejam aplicadas na cabeça do indivíduo para evocar potenciais quando se utiliza a ECT. Para o campo magnético esses tecidos são transparentes, assim muito menos energia é necessária para gerar a atividade neuronal no procedimento de EMT. (Harsey D., 2001)

A princípio, bobinas com novos desenhos, a exemplo da bobina em forma de 8, foram criadas para gerar campos magnéticos mais focais (Cohen L.G. et al., 1990) e usadas para avaliar o envolvimento cortical e suas conexões em funções como a memória e o aprendizado (Pascoal-Leone A. et al., 1996), a visão (Paus T. et al., 1997) e o controle muscular (Cohen L.G. et al., 1989). O estímulo do córtex motor M1, por produzir uma resposta muscular imediata, constitui a melhor região cortical para se analisar os efeitos da Estimulação Magnética Transcraniana. (Kossev A.R. et al., 2003) A resposta motora produzida por um único estímulo aplicado nessa região é denominada de Potencial Motor Evocado (Motor Evoked Potential - MEP), mensurada por medidas eletrofisiológicas. (Huerta PT, Volpe BT, 2009)

Com base nesse processo de mapeamento das funções corticais motoras, principalmente da mão, estudos sobre as diferentes excitabilidades corticais puderam definir o padrão de Limiar Motor (LM). O LM, por definição, é a menor intensidade de estímulo capaz de produzir um movimento no hálux contralateral, que pode variar 
individualmente. A fim de que não ocorram erros, a bobina deve ser posicionada exatamente na região responsável pelo movimento da musculatura do hálux, pois quanto mais distante dessa região, maior será a intensidade do LM. (McConnell K.A. et al., 2001) A precisão dessa medida deve ser respeitada uma vez que a definição da intensidade do estímulo a ser usada em um protocolo de EMT é uma percentagem do LM. Esse é o único parâmetro que analisa as características individuais, portanto, antes de qualquer procedimento deve ser calculado. Os limites de segurança na intensidade do estímulo são inclusive postulados de acordo com o LM (PascualLeone A. et al., 1993). Diferenças no percentual do LM podem promover diferenças na duração e qualidade dos efeitos terapêuticos, além de causar efeitos diferentes em regiões distantes das estimuladas. (Mochizuki H. et al., 2007)

A EMT tem utilidade indiscutível para o estudo da neurofisiologia e para o neurodiagnóstico de afecções motoras. O uso da Estimulação Magnética Transcraniana repetitiva (EMTr) como forma de tratamento exige séries de estímulos sequenciados padronizados que duram alguns minutos, denominados paradigmas. A principal consequência desse uso está no efeito neuromodulador somatório das séries envolvendo os neurotransmissores e as vias neuronais, anteriormente, citadas. (Lang N. et al., 2008; Ben-Shachar D. et al., 1999)

De acordo com efeitos sobre a neurofisiologia da facilitação e a depressão neuronal nas diferentes regiões corticais, que seguem o mesmo padrão de formação de potenciais de longo prazo, a serem descritos no hipocampo do item 1.2.2, que explica o paradigma de Theta Burst, dois tipos de efeitos podem ser adquiridos através da EMT. Os protocolos que definem um efeito facilitador, o aumento da intensidade dos potenciais, estão relacionados a frequências maiores do que $1 \mathrm{~Hz}$. O efeito inibitório que diminui a intensidade dos potenciais relaciona-se a frequências menores do 1 Hz. (Marcolin M.A., 2004)

Em psiquiatria, a EMTr vem sendo usada desde 1992 com resultados clínicos surpreendentes, comprovados pela maioria dos estudos realizados. Concluiu-se, inicialmente, que a EMTr sobre o córtex pré-frontal esquerdo no tratamento da depressão é uma técnica segura (Pascual-Leone A. et al., 1996a; Avery D., George M.S., 1998; Triggs W. et al., 1999; Loo C.K. et al., 1999; Padberg F. et al., 1999). Desde então, os resultados positivos são publicados anualmente quanto à eficácia 
no tratamento de transtornos do humor (Alan C. et al., 2011), transtorno obsessivo compulsivo (Mantovani A. et al., 2010) e para fissura em pacientes dependentes de cocaína (Camprodon J.A. et al., 2007).

No caso de pacientes esquizofrênicos, existem evidências de eficácia da EMTr tanto para os sintomas positivos, relacionados a alucinações auditivas (Aleman A., Sommer I., Kahn R., 2007; Hoffman R.E. et al., 2003), quanto para os sintomas negativos (Barr M.S. et al., 2012). Os efeitos sobre a cognição apresentam-se quando se estimulam diretamente as regiões responsáveis por tais processos e também quando se tratam sintomas das patologias apresentadas anteriormente, mostrando que a neuromodulação propriamente dita pode tornar o cérebro mais eficiente. (Guse B., Falkai P., Wobrok T., 2010) Há evidências que demonstram melhora em funções cognitivas em pacientes que estiveram em tratamento com Estimulação Magnética Transcrâniana para diversos transtornos psiquiátricos como Depressão Maior, Doença de Alsheimer, Esquizofrenia, Transtorno do Espectro Autista e Transtorno de Déficit de Atenção e Hiperatividade. (Demirtas-Tatlidade A. et al., 2013)

Mesmo com a demonstração dos efeitos positivos e promissores da EMT, inúmeros cuidados estão sendo avaliados para que conceitos éticos relacionados à utilização desse procedimento em pesquisa e como forma de tratamento sejam considerados. (Post A., Keck M.E. et al., 2001) A primeira preocupação é com a ocorrência de convulsões. Apesar da baixa incidência, o simples fato de estar promovendo a eletrofisiologia do tecido nervoso central pode gerar riscos quanto a processos de instabilidade. Outra preocupação está relacionada aos efeitos não focais. Sabe-se que o cérebro é um órgão altamente integrado e ações em determinadas regiões podem ter influências desproporcionais em outras. Além disso, ações sobre o temperamento, caráter e personalidade devem ser melhores avaliadas, bem como cuidados devem ser tomados quanto ao uso em indivíduos sem qualquer patologia para benefícios de desempenho. (Hamilton R., Messing S., Chatterjee A., 2011)

Existem contraindicações relativas para a aplicação de EMT em pacientes que sofreram algum tipo de neurocirurgia (especialmente se têm algum clipe metálico inserido que possa ser desalojado ou aquecido pela ação da EMT) e pacientes que portam algum aparelho biomédico (como marca passo) pelos riscos de interferência no funcionamento desse aparelho. O músculo cardíaco pode ser estimulado com a bobina magnética em caso do uso de altas frequências. (Rossi S. et al., 2009) 


\subsubsection{Estimulação em "Theta Burst"}

Os primeiros estudos a mostrarem a fisiologia dos neurônios que produzem impulsos na frequência Theta e sua importância para a formação de potenciais de longo prazo no cérebro foram apresentados na década de setenta. (Boravova A.L., 1976) Confirmou-se a existênciade grupos de células que se comunicam principalmente com a região dorsal do hipocampo em uma sequência de pulsos na frequência de ondas Theta.

Essa fisiologia será compreendida mais adiante. Existem células dentro do hipocampo denominadas de Iniciadoras do Burst que se dispõem principalmente na região CA3 do hipocampo. São sensíveis a comportamentos excitatórios simultâneos Theta que ocorrem no Neocórtex. Ao serem estimuladas, têm um alto poder de recrutamento para as células adjacentes no Hipocampo gerando Bursts, sequências de ondas agudas sincrônicas de alta frequência, espaçadas entre si por frequências Theta, que tem como "output" principalmente o Córtex Entorrinal. Essa atividade está diretamente ligada à formação da memória. (Buzsáki G. et al., 1990)

O aprendizado também faz parte desse processo, quando a atividade espontânea singular unitária na região CA1 do hipocampo entra em sincronia com o ritmo Theta, descrito anteriormente. (Otto T. et al., 1991) Esse parece ser o ritmo ideal para a formação de potencial de longa duração (LPT - "Long Term Potential"), tanto no hipocampo (Larson J., Wong D., Lynch G., 1986), quanto no córtex olfatório (Jung M.W., Larson J., Lynch G., 1990). O comportamento de aprendizagem fica caracterizado a partir do momento que existe a comprovação da formação de sinapses específicas em decorrência dos potenciais de longa duração. (Larson L., Lynch G., 1989)

A formação de potenciais de longa duração em hipocampo, responsáveis pela memória e o aprendizado, envolvem as sinapses que conectam as regiões CA1 e CA3. Estudos em modelos animais demonstram que a ativação desse sistema pelos Bursts de onda Theta é responsável pelo aumento da ancoragem da Proteína Kinase A (PKA) pré-sinápticas em C3, que modula a liberação de substância ativadoras dos receptores de glutamato. Influência i demonstrada tanto sobre os receptores NMDA (N-Metil-D-Aspartato) quanto sobre os AMPA (Ácido Alfa Amino 3 Hidroxi 5 Metil 4 Isoxazolepropionico). (Nie T. et al., 2007) 
O uso da frequência de ondas Theta através do protocolo que utiliza "Bursts" - sequências de três estímulos em alta frequência a $50 \mathrm{~Hz}$ espaçados por intervalos de 200 milisegundos - pode ser feito em diferentes padrões. Os dois mais importantes são: o intermitente, com 2 segundos de Bursts, seguido de pausas de 8 segundos, com efeito facilitador, aumentando as amplitudes dos potenciais, simulando os potencia de longa duração, e o contínuo, sem pausas, com efeito depressor, diminuindo as amplitudes dos potenciais, simulando depressões de longa duração. (Huang Y.Z. et al., 2005)

Os efeitos da estimulação magnética com Theta Burst utiliza a ação sobre receptores de NMDA relacionados ao neurotransmissor Glutamato. Esse efeito ocorre tanto para formação de facilitação, quanto para depressão e está relacionado com a neuroplasticidade. (Huang Y.Z. et al., 2007) A formação de novas sinapses e a geração de efeitos mais prolongados e permanentes explica os efeitos mais prolongados desse protocolo.

Assim como demonstrado nos protocolos de Estimulação Magnética Transcraniana, o uso do Theta Burst também promove efeitos à longa distância no córtex cerebral. Os estudos em córtex motor têm comprovado que a variação da intensidade pode gerar efeitos diferentes no hemisfério contralateral. Estimulação a $80 \%$ do limiar motor tem efeito inibitório, de $90 \%$ a $100 \%$ ocorre uma mistura de facilitação e inibição no córtex contralateral e a intensidade de $110 \%$ parece prevalecer a facilitação. Provavelmente, o que ocorre na intensidade de $100 \%$ do limiar motor é o cancelamento dos efeitos apesar de existirem conexões que realizam ambas as funções, facilitadoras e inibitórias, entre os hemisférios. (Mochizuki H. et al., 2007)

Existem formas naturais de aumentar o poder facilitador na formação de potenciais de longa duração que podem ser utilizadas após o tratamento com Theta Burst. Estudos em córtex motor mostraram que a contração muscular logo após o procedimento pode ter esse efeito. (Huang Y.Z. et al., 2008) Por outro lado, também existem formas de se inibir a formação dos potencias de longa duração. Estudos com animais demonstraram que se os potenciais são colocados em situação novas logo após a sua formação, esses são revertidos pelos novos estímulos. (Zou Q., Poo M.M., 2004) O padrão de estimulação magnética, proposto pelo protocolo Theta Burst, com espaços entre os estímulos, tem a característica de inibir o processo de reversão da 
formação de potenciais de longa duração, fortalecendo a criação de novas sinapses que representam a memória e o aprendizado. (Zou Q., Poo M.M., 2004)

Em seres humanos, bons resultados têm sido apresentados em sintomas negativos da esquizofrenia (Bor J, et al., 2008). Quanto aos efeitos adversos, estudos já vêm mostrando sua seguridade e impacto positivo no humor, cognição e no descanso do eletroencefalograma (Grossheinrich N. et. al, 2009). Trata-se de um protocolo novo, com um futuro importante no prolongamento da eficiência terapêutica dos tratamentos com EMT.

\subsubsection{EMT em Crianças}

Algumas peculiaridades vêm sendo observadas quando se avalia a fisiologia elétrica cerebral de crianças e adolescentes e suas respostas clínicas quando submetidos à EMT. Além disso, crianças e adolescentes apresentam reações diferenciadas quando posicionadas na cadeira e quando em contato com a bobina. Tanto o padrão de ansiedade, quanto a sensibilidade mais imatura a estímulos do ambiente, especialmente nos pacientes neurológicos e psiquiátricos, podem gerar sensações não encontradas nos adultos. (Coarkin P.E., 2011)

O limiar motor, por exemplo, apresenta uma evolução dinâmica durante o desenvolvimento. Aumenta progressivamente do nascimento até o terceiro mês de vida, contando com o fato de que as redes cruzadas cortico espinhais continuam seu desenvolvimento depois do nascimento. A partir dessa idade, o limiar motor começa a diminuir linearmente (Eyre J.A. et al., 2001).

Mesmo com essas nuanças características da infância, mais de oitocentas crianças documentadas até 2008 passaram por esse procedimento sem apresentar efeitos colaterais importantes. Trezentas delas apresentavam alterações neurológicas em diferentes níveis, incluindo vinte e cinco com epilepsia. Revisões focando os efeitos colaterais da EMT em crianças confirmaram a segurança do procedimento (Frye R. E. et al. 2008). Além disso, os protocolos de estimulação possuem alto nível de segurança tanto quanto os valores de risco de lesão, pesquisados em modelos animais. (Counter S. A. 1993; Gates J. R. et al., 1992; Sgro J. A. et al., 1991). 
Em estudo publicado em 2012, quarenta crianças foram submetidas a uma sessão de EMT com o protocolo de Theta Burst intermitente e contínuo com o objetivo de se analisarem dados de segurança. 11,6\% delas apresentaram efeitos adversos leves que variaram entre cefaleia, movimentos da musculatura do pescoço e dos dedos. (Wu S.W. et al., 2012)

Assim, pode-se concluir que, apesar das peculiaridades específicas da idade, crianças e adolescentes seguem o mesmo padrão de tolerabilidade apresentado pelos adultos. Novos estudos que irão consagrar a alta tolerabilidade do tratamento nesse perfil de pacientes devem surgir nos próximos anos.

\subsubsection{EMT em Indivíduos com Transtorno do Espectro Autista}

Evidências têm demonstrado melhora das funções cognitivas em pacientes que estiveram em tratamento com EMT para diversos transtornos psiquiátricos como Depressão Maior, Doença de Alsheimer, Esquizofrenia, Transtorno do Espectro Autista e Transtorno de Déficit de Atenção e Hiperatividade. (Demirtas-Tatlidade A. et al., 2013)

Até 2013, todos os estudos publicados que utilizaram protocolos de Estimulação Magnética Transcraniana com a finalidade de interferir na problemática do Transtorno do Espectro Autista tomaram por base o entendimento da excitabilidade cortical exagerada do córtex cerebral. Dessa forma, acreditava-se que, através de procedimentos inibitórios, o desequilíbrio entre a excitação cortical e a inibição cortical, gerada pela fisiopatologia, anteriormente comentada, poderia equilibrar as funções cerebrais danificadas pelo transtorno. (Sokhadze E. et al., 2009, 2010; Baruth J.M. et al., 2010; Sokhadze, E. et al., 2012; Enticott P.G. et al., 2012; Fecteau S. et al., 2011)

O primeiro grupo a publicar resultados realiza o mesmo procedimento de inibição do Córtex Pré Frontal Dorso Lateral iniciando com dois trabalhos que propunham 2 sessões semanais por 3 consecutivas à esquerda utilizando $90 \%$ do limiar motor e uma frequência de 0,5 Hz. O primeiro estudo, publicado em 2009, mostra melhora no processamento de figuras, medidas através da oscilação da frequência de ondas GAMA após potencial evocado ser gerado por estímulo visual 
de figuras ilusórias. (Sokhadze E. et al., 2009) O segundo, apresentado no ano seguinte, mostra melhora da resposta cerebral a estímulos novos através de estudos eletrofisiológicos em componentes frontais, fronto parietais e parieto occipitais, provocados por potenciais evocados. (Sokhadze E. et al., 2010) Apesar da mudança positiva na eletrofisiologia, mudanças discretas registraram-se na clínica.

A partir desses resultados, o grupo passa a utilizar um protocolo com 1,0 Hz de frequência e a realizar 2 sessões semanais por 6 consecutivas, sendo 3 em Córtex Pré Frontal Dorso Lateral à esquerda e o restante à direita. Repetindo o mesmo protocolo de avaliação do primeiro estudo, os pesquisadores conseguem mostrar uma mudança significativa na estabilidade das oscilações GAMA durante 0 processamento de figura, acrescida de uma melhora nos padrões de comportamentos restritos e repetitivos, como também de irritabilidade. (Baruth J.M., 2010) Utilizando o mesmo protocolo de intervenção, o último trabalho publicado pelo grupo mostrou mudanças eletrofisiológicas dos sujeitos após os erros de nomeação: ondas negativas e positivas com maior amplitude e aumento do tempo de reação após os erros cometidos. (Sokhadze E. et al., 2012)

A partir desses estudos, outros grupos testam novos protocolos pautados no mesmo raciocínio. Pacientes com Transtorno do Espectro Autista com dificuldades na habilidade de controle motor foram avaliados após três sessões de Estimulação Maganética Transcraniana inibitória em área motora e área motora suplementar à esquerda e mostraram melhora na eletrofisiologia da preparação do movimento. (Enticott P.G. et al., 2012)

Para analisar a resposta do procedimento na comunicação expressiva, o grupo, chefiado por Pascoal-Leoni, propôs intervenção na área de Broca. O estudo mostrou melhora na resposta de nomeção verbal em pacientes de desenvolvimento típico e com Transtorno do Espectro Autista após uma sessão de Estimulação Magnética Transcraniana inibitória nas regiões "pars triangularis" (área 45 de Broadmann) à esquerda. Por outro lado, resposta do mesmo estímulo ao "pars opercularis" (área 44 de Broadmann), também à esquerda, tornou lenta a latência do processo de nomeação. Ambas as áreas fazem parte da área de Broca e, portanto, relacionam-se com funções expressivas da comunicação. (Fecteau S. et al., 2011) 
2 Justificativa 
Vive-se um momento em que as bases fisiopatológicas relacionadas ao quadro do Transtorno do Espectro Autista definem-se de forma mais evidente. Assim sendo, a presença de múltiplos fatores etiológicos inter-relacionando-se em fases muito precoces do desenvolvimento justifica a presença de quadros clínicos tão diferentes. As formas de tratamentos com psicofármacos têm uma abordagem inespecífica até o presente momento com ações generalizadas no sistema nervoso, gerando ações pouco eficientes sobre as bases dos sintomas do Autismo e muitos efeitos adversos.

A linha de sintomas relacionados aos comportamentos restritos e repetitivos apresenta-se como uma marca característica, presente em todas as formas de manifestação do Transtorno do Espectro Autista. Além disso, influenciam diretamente na gravidade dos sintomas relacionados ao impacto na sociabilidade e no desenvolvimento da linguagem. Apresentam características específicas ao longo do desenvolvimento e relacionam-se diretamente, em suas bases fisiopatológicas, com as funções cognitivas. Existem fortes evidências da correlação proporcional inversa da função da flexibilidade cognitiva com os comportamentos restritos e repetitivos. A melhora dessa função cognitiva pode representar mudanças no padrão de comportamento.

A Estimulação Magnética Transcraniana, uma nova forma de abordagem das anormalidades que aferem o sistema nervoso, tem demonstrado, em pesquisas recentes, alta eficiência e diminutos efeitos adversos, por ser específica e de fácil aplicação, além de alta tolerabilidade. Essa técnica pode facilitar ou inibir o funcionamento de determinada função cortical e modular sua relação com outras regiões, mesmo que distantes das regiões estimuladas. O protocolo Theta Burst apresenta uma capacidade de fortalecer a formação de potenciais de longo prazo e fortalecer a conectividade nas regiões a serem estimuladas. Por isso, essa técnica tem mostrado efeitos terapêuticos mais duradouros.

Ao analisar a fisiopatologia do Transtorno do Espectro Autista, existem duas formas de se influenciar no córtex dos indivíduos com essa patologia através da 
Estimulação Magnética Transcraniana. Os erros promovidos pela genética responsável pela formação, migração e posicionamento das células corticais geram inadequação do posicionamento dessas células nas minicolunas corticais, provocando uma dessincronização entre o equilíbrio da excitação e inibição. A literatura vem se empenhando em inibir o Córtex Pré Frontal Dorso Lateral com a intenção de corrigir a hiperexcitabilidade gerando mudanças positivas na eletrofisiologia cortical. O presente estudo tem por base a ação sobre as alterações na formação e consolidação das conexões sinápticas, alteração que gera a dificuldade na conectividade com prejuízos importantes nas funções cognitivas e no aprendizado. Visa a melhorar a conectividade entre o córtex pré-frontal e as vias de formação de memória e aprendizado no hipocampo, aproveitando a capacidade do protocolo de Theta Burst.

Trata-se do primeiro protocolo que recorre a ao efeito facilitador da Estimulação Magnética Transcraniana (MTR) no tratamento de pacientes com Autismo. 
3 Objetivos 


\subsection{Objetivo Geral}

Avaliar o padrão qualitativo e quantitativo da resposta executiva na função de flexibilidade cognitiva, através do teste Wisconsin Sort Card Test (WSCT); no tempo de processamento, através do STROOP Test, e do padrão clínico; no comportamento restrito e repetitivo, pelos instrumentos da Escala de pensamentos Obsessivos e comportamentos Compulsivos de Yale Brown (YBOCS) e da Escala dos Comportamentos Repetitivos (Repetitive Behavior Scale - RBS), após avaliação, propor protocolo de intervenção com Estimulação Magnética Transcraniana no Córtex Pré Frontal Ventro Lateral (CPDVL) direito em sua porção antero inferior em pacientes com Transtorno do Espectro Autista de alto funcionamento.

\subsection{Objetivos Específicos}

- Correlacionar as mudanças encontradas nos diferentes testes neuropsicológicos com as ocorridas nas escalas.

- Analisar a possibilidade de as mudanças relacionadas à inflexibilidade cognitiva estarem relacionadas ao comportamento restrito e repetitivo.

- Avaliar a manutenção das mudanças após três meses da realização do protocolo de Estimulação Magnética Transcraniana.

- Analisar a possibilidade de se estudar a intervenção de Estimulação Magnética Transcraniana como opção terapêutica para os comportamentos restritos e repetitivos nos indivíduos com o diagnóstico de Autismo de alto funcionamento. 
4 Métodos 
Trata-se de Estudo com procedimento sistematizado de intervenção, com onze pacientes autistas que serão tratados no âmbito do Comportamento Restrito e Repetitivo com Estimulação Magnética Transcraniana. O Estudo foi aprovado pelo comitê de Ética da Faculdade de Medicina da Universidade de São Paulo pelo protocolo de pesquisa número 043/11.

\subsection{Sujeitos}

Participaram do estudo 11 indivíduos com diagnóstico de Autismo, apresentando comportamento restrito e repetitivo de impacto na funcionalidade, do gênero masculino, com idade cronológica que varia de 09 a 17 anos, com coeficiente intelectual em nível acima de 75. Os sujeitos da pesquisa foram selecionados no Ambulatório de Transtornos do Espectro Autista do Instituto de Psiquiatria do Hospital das Clínicas da USP, coordenado pela Dra. Helena Brentani (PROTEA). São pacientes Autistas de alto funcionamento sem comorbidades neurológicas e quadros psiquiátricos agudos. Dessa forma, consegue-se isolar e correlacionar melhor as alterações clínicas que estão em análise neste estudo e minimizar as intercorrências ocorridas durante os procedimentos de EMT.

\subsubsection{Critérios de inclusão}

- Adolescentes com idade entre 09 e 17 anos.

- Assinatura do termo de consentimento livre por pais ou responsáveis para sua participação na pesquisa.

- Diagnóstico de Autismo (F84), realizado por um psiquiatra infantil, através dos critérios diagnósticos da Classificação Internacional e Doenças, em sua Décima revisão (CID-10), da Organização Mundial de Saúde. 


\subsubsection{Critérios de exclusão}

- História de comorbidades neurológicas (crises convulsivas, lesões expansivas, outras síndromes genéticas).

- História de comorbidades psiquiátricas agudas (surtos psicóticos, crises de instabilidade afetiva).

- Indivíduos com problemas clínicos que impeçam o processo de estimulação.

- Indivíduos submetidos à neurocirurgia com implante.

- Indivíduos com história de problemas de acuidade auditiva.

- Indivíduos com coeficiente de inteligência menor do que 75.

\subsection{Material}

\subsubsection{Instrumentos Diagnósticos}

\section{Classificação de transtornos mentais e de comportamento CID-10}

A Classificação de Transtornos Mentais e do Comportamento que integra a “Classificação Internacional de Doenças,” em sua décima revisão (OMS, 1993), apresenta critérios diagnósticos clínicos detalhados para pesquisa de quadros de Autismo. Para diagnóstico desse transtorno há necessidade de um desenvolvimento anormal ou comprometido que se inicia antes da idade de três anos. Há um total de 12 itens divididos entre as áreas de interação social, linguagem e jogo simbólico ou funcional. A presença de seis desses itens (pelo menos dois itens relacionados à interação social, um item relacionado à linguagem e um item relacionado à capacidade criativa das crianças) confirma o diagnóstico. A triagem dos pacientes foi realizada pelo pesquisador responsável por este Estudo, psiquiatra da infância e adolescência. (Anexo 1) 
2. Kiddie Schedule for Affective and Schizophrenia for School AgedChildrenChildhood - Ratreamento (K-SADS)

Trata-se de entrevista clínica semiestruturada, baseada nos critérios diagnósticos do DSM-IV. Apesar de ter função diagnóstica, utilizou-se somente a parte de rastreamento, no momento de triagem dos pacientes, para identificar comorbidades psiquiátricas agudas, relacionadas aos critérios de exclusão. $\mathrm{O}$ instrumento foi aplicado por profissional contratado habilitado para realizar a entrevista.

\subsubsection{Instrumentos de Avaliação das Funções Corticais Superiores}

1. Escala de Inteligência Wechsler para Crianças - terceira edição (WISC - III)

A Escala de Inteligência Wechsler para Crianças (WISC-III) representa a terceira edição dessa Escala e teve por finalidade avaliar a capacidade intelectual dos pacientes. É um instrumento que possibilita a avaliação da capacidade intelectual de crianças com idades entre 6 anos e 0 meses a 16 anos e 11 meses. O WISC-III é composto por 13 subtestes, sendo 12 deles mantidos do WISC-R e um novo subteste, Procurador de Símbolos, organizados em dois grupos: Verbais e Perceptivos-motores ou de Execução, que são aplicados nas crianças em ordem alternadas, ou seja, um subteste de Execução e depois um subteste verbal e vice-versa. Além do coeficiente intelectual (QI total), é possível avaliar o QI verbal e o QI de execução separadamente a partir das treze provas propostas, sendo que cada uma avalia um aspecto diferente da inteligência. São elas: Completar Figuras, Informação, Código, Semelhanças, Arranjo de Figuras, Aritmética, Cubos, Vocabulário, Armar Objetos, Compreensão, Procurar Símbolos (opcional), Dígitos (opcional) e Labirintos (opcional). Além do QI também é possível avaliar mais quatro índices específicos no desempenho da criança: Compreensão Verbal, Organização Perceptual, Resistência à distração e Velocidade de Processamento. AEscala de Inteligência Wechsler para Crianças foi utilizada na fase de triagem dos pacientes, realizada por profissional especializado e habilitado, para identificar os pacientes com coeficiente de Inteligência menor do que 75, que não poderiam participar do estudo segundo os critérios de exclusão. 


\section{Wisconsin Sort Card Test - WSCT}

Trata-se de um teste de função executiva que avalia primariamente a flexibilidade cognitiva - capacidade de um indivíduo em se permitir mudar de atividade funcional cerebral sem perseverar na atividade anterior. Por meio desse teste também se podem medir a velocidade, a qualidade do processamento e a formação de conceitos.

Através de tarefas visuais, o indivíduo é apresentado a uma sequência fixa de cartas que diferem quanto à cor, ao número e às formas dos desenhos. Durante o teste são montadas três pilhas de cartas em que os sujeitos testados devem escolher em qual delas a carta seguinte será depositada. $\mathrm{O}$ aplicador somente diz ao avaliado se ele colocou na pilha certa ou errada. Os indivíduos testados precisam identificar o padrão que está prevalecendo e as mudanças nesse padrão que ocorreram em determinados momentos sem o aviso prévio. O teste completo tem 128 cartas. No presente estudo aplicou-se a versão simplificada com 64 cartas. As correções geram cinco índices: erros totais, respostas perseverativas, erros perseverativos, erros não perseverativos e formação de nível conceitos.

Esse teste foi utilizado como medida de eficiência primária, principalmente para a variável, Respostas Perseverativas. As outras variáveis da correção, consideradas mais relevantes, são: os erros perseverativos e a formação de nível conceitual, as quais representam mais fielmente a flexibilidade cognitiva e a influência desta na capacidade do individuo em formar novos conceitos. Assim, quanto maior forem os valores das respostas perseverativas e erros perseverativos, menor a formação de novos conceitos. Os valores de correção de cada item são apresentados em forma de percentual. Foram feitas duas aplicações por profissional especializado e qualificado, antes e depois da aplicação do procedimento de Estimulação Magnética Transcranina com o intuito de medir as diferenças das repostas. 


\section{3. $\quad$ STROOP Test}

O SROOP é um teste neuropsicológico que avalia atenção, flexibilidade do pensamento, atenção seletiva, resistência à interferência, impulsividade e tempo cognitivo. É divido em três etapas. Em cada uma delas o indivíduo avaliado deve nomear sequencialmente cores apresentadas numa cartela em que as cores estão presentes em pequenos quadrados. Cada cartela representa uma etapa. Cada etapa apresenta distrativos de maior dificuldade escritos dentro dos quadrados em que as cores estão alocadas.

Neste estudo, o número de erros cometidos pelo sujeito durante a nomeação das cores e o tempo de resposta de cada cartela são quantificados e somados. O teste foi aplicado por profissional especializado e qualificado antes e depois do procedimento de Estimulação Magnética Transcraniana com o objetivo de medir as diferenças das repostas.

\subsubsection{Escalas de avaliação de sintomas}

1. Escala de Comportamento Repetitivo - Revisada (Repetitive Behavior Scale Revised - RBS-R):

Trata-se de instrumento aplicado aos pais e cuidadores que detalha qualitativamente os sintomas relacionados ao Comportamento Restrito e Repetitivo em pacientes com Transtorno do Espectro Autista. Apresenta um total de quarenta e três itens que podem ser classificados entre 1 a 4 pontos de acordo com o grau de impacto e frequência, tempo de duração e prejuízo no cotidiano. A escala é dividida em seis subescalas: Comportamento Estereotipado, Comportamento Auto Agressivo, Comportamento Compulsivo, Comportamento Ritualístico, Comportamento de Insistência na Mesmice e Comportamento Restrito. (Bodfish, J.W 1999) Trata-se de testagem considerada padrão ouro para avaliação do impacto do Comportamento Restrito e Repetitivo.

Neste estudo, a Escala de Comportamentos Repetitivos foi utilizada para avaliar a visão dos pais e responsáveis sobre as mudanças ocorridas nos 
comportamentos dos sujeitos após o procedimento. Dois tipos de mudanças podem ter relevância. Primeiramente, observam-se as mudanças quantitativas em que os escores de cada subescala e as somatórias de todas poderiam diminuir ou aumentar. A partir dessa etapa, observa-se $\mathrm{s}$ se ocorreram mudanças nos padrões dos comportamentos restritos e repetitivos. Isso ocorre quando temos aumento de uma subescala em detrimento da diminuição de outra. Considerando que progressivamente as subescalas representam comportamentos de maturidades cognitivas diferentes, as mudanças de padrões podem representar amadurecimento do perfil cognitivo dos sujeitos, como ocorre naturalmente durante a vida dos pacientes com Transtorno do Espectro Autista. (Esbensen AJ et al 2009)

A escala foi aplicada em períodos que antecederam e precederam o procedimento de Estimulação Magnética Transcraniana por profissional especializado e qualificado com o pais e responsáveis. (Anexo 2)

2. Escala de pensamentos obsessivos e comportamentos compulsivos de Yale Brown (Y-BOCS):

Escala criada por Goodmann em 1989 com o objetivo de pontuar os sintomas relacionados às bases diagnósticas do Transtorno Obsessivo e Compulsivo. É dividida em duas sessões de cinco questões cada. As questões de um a cinco estão relacionadas aos pensamentos obsessivos e as de seis a dez aos comportamentos compulsivos. Cada questão precisa apresentar cinco tipos de respostas de " 0 " a "4" que variam progressivamente de acordo com a gravidade dos sintomas apresentados.

A ideia de se utilizar uma escala de sintomas obsessivos e compulsivos para analisar o comportamento restrito e repetitivo em pacientes com Transtorno do Espectro Autista é baseada na suposição de que, apesar dos sintomas serem semelhantes, podem ter uma origem fisiopatológica diferente. Como influenciam diretamente no funcionamento de regiões que orientam a flexibilidade cognitiva, esperam-se mudanças diferentes das encontradas nas escalas de avaliação específicas para os sintomas relacionados ao quadro de Autismo.

Utilizou-se, neste estudo, a versão de adulto adaptada para crianças e adolescentes. Somente foram consideradas as questões relacionadas aos sintomas 
compulsivos. Os sintomas obsessivos não foram considerados relevantes. Os relacionados aos pensamentos obsessivos foram desprezados. As questões foram aplicadas aos pais e cuidadores em períodos que antecederam e precederam o procedimento de Estimulação Magnética Transcranina por profissional especializado e qualificado. (Anexo 3)

\subsubsection{Neuronavegação}

A marcação correta do ponto de estimulação foi feita através de um sistema de neuronavegação (VECTOR Vision BRAIN LAB®). O método é baseado no aproveitamento do espaço estereotático por triangulação sem a necessidade de halo craniano.

Após procedimento de ressonância magnética de crânio, as imagens do cérebro dos sujeitos foram reconstruídas em três dimensões pelo software "BrainSite". Em seguida, este programa identifica as posições da bobina de TMS e do crânio através de antenas acopladas em três posições: nos adaptadores da bobina do aparelho de Estimulação Magnética Transcraniana, numa faixa que é i prendida na cabeça do paciente e num "pointer" que é posicionado em pontos estratégicos na cabeça. A triangulação de todas essas antenas monitoradas pelo sensor de posição óptica capta a posição exata em que a bobina está posicionada no espaço e essa imagem aparece em tempo real pelo monitor. Para todos os sujeitos, a região exata do CPFVL direita em sua porção anteroinferior é marcada na toca dos mesmos, virando assim a referência de ponto de estimulação.

Além do ponto de estimulação, também se utilizou a neuronavegação para conferir o ponto relacionado à testagem do Limiar Motor Este é calculado através da marcação tradicional através das coordenadas anatômicas realizadas na toca.

\subsubsection{Estimulação Magnética Transcraniana}

Utilizou-se para a Estimulação Magnética Transcraniana de um estimulador magnético de alta velocidade da marca Dantec Magpro 2 com uma bobina em forma de oito (Medtronic Inc., USA). O aparelho em questão pertence ao Ambulatório de 
Neuromodulação do Instituto de Psiquiatria do Hospital das Clínicas da Universidade de São Paulo.

Os sujeitos foram acomodados em uma cadeira declinável durante o procedimento. Com uma toca branca marcamos o posicionamento da inserção das duas sobrancelhas, dos tragus direito e esquerdo e da proeminência occipital. Após o cálculo dos pontos médio entre os dois tragus e as inserções das sobrancelhas, traçaram-se duas linhas: uma média sagital que une o ponto médio das inserções das sobrancelhas e a proeminência occipital e outra que liga os dois tragus passando pelo ponto médio da linha anterior.

O Ponto do Limiar Motor é calculado com cinco centímetros do ponto de cruzamento das duas linhas para a esquerda. Por meio do procedimento de Neuronavegação, marcou-se o Ponto de Estimulação e conferiu-se o Ponto do Limiar Motor. Alocando a bobina no Ponto do Limiar Motor, calculou-se a intensidade do Limiar Motor. Este tem por base a intensidade mínima para realizar cinco movimentos no Halux contralateral. O Limiar Motor é recalculado a cada cinco sessões de TMS. Após alocar-se a bobinar na região anteroinferior do CPFVL correspondente a área 47 de Boradmann, iniciou-se o protocolo de Theta Burst programado no sistema, através de software Neuro-MS.Net. A duração da sessão é de 300 segundos.

Protocolo de Theta Burst:

- 15 sessões em 15 dias úteis;

- $100 \%$ do potencial total do Limiar Motor;

- $50 \mathrm{~Hz}$ de frequência de cada estímulo de um Burst;

- $5 \mathrm{~Hz}$ de frequência de cada Burst;

- 30 séries;

- 2 segundos ligado;

- 8 segundos desligado;

- Área: 47 de Brodmann norteado pela Neuronavegação. 


\subsection{Procedimento}

Na fase 1, foi apresentado aos pais e responsáveis dos sujeitos selecionados o Termo de Consentimento Livre e Esclarecido.(Anexo 4) Os pacientes foram selecionados segundo avaliação clínica baseada nos critérios diagnósticos do CID-10 e K-SADS, pareados pelo nível intelectual (QI maior ou igual a 75), satisfazendo os critérios de inclusão descritos anteriormente. Após a assinatura do termo, os pacientes são encaminhados aos exames complementares, procedimento de Ressonância Magnética de Crânio e um Eletroencefalograma. Essa fase teve o objetivo de confirmar o diagnóstico de Transtorno do Espectro Autista e conferir se existia algum quadro neurológico ou psiquiátrico agudo que fosse impeditivo da realização do procedimento. Apesar de se estar excluindo os pacientes de nível intelectual abaixo do padrão de normalidade, esse critério não é impeditivo da realização do procedimento. Por se tratar de um estudo experimental, dois sujeitos que possuíam coeficiente de inteligência abaixo do normal foram selecionados a prosseguir para as próximas fases do estudo.

$\mathrm{Na}$ fase 2, foram realizadas as avaliações prévias à Estimulação Magnética Transcraniana. Os parentes dos sujeitos selecionados na fase 1 submeteram-se às entrevistas RBS-r e Y-BOCS e os pacientes aos testes de função executiva WSCT e STROOP test. Essa fase teve por objetivo a formatação das variáveis clínicas e comportamentais prévias ao procedimento.

$\mathrm{Na}$ fase 3, é caracterizada pelo procedimento de Estimulação Magnética Transcraniana. Os sujeitos se apresentam diariamente, cinco dias por semanas, por três semanas em um total de 15 sessões. Cada sessão teve duração de 15 minutos e foram divididas em três fases. Primeiro, nos 5 minutos iniciais, recebem-se o sujeito e os familiares para um questionário (Screening de segurança em adultos da Estimulação Magnética Transcraniana - Transcranial Magnetic Stimulation Adultt Safety Screen - adaptado para crianças e adolescentes) que representa uma bateria de sintomas que poderiam ocorrer após cada sessão. Assim pode-se avaliar tanto o grau de satisfação e angústia dos pais e parentes. Em seguida, o sujeito é encaminhado à cadeira reclinável e posicionado para início da Estimulação. Após alocação da toca e posicionamento da bobina na posição marcado, inicia-se a sessão que dura outros 5 
minutos. Nos 5 minutos finais, o sujeito recebe um lanche e um questionário de sintomas imediatos é aplicado ao paciente. (ANEXO 4)

Por algum problema clínico ou por intolerância qualquer, a sessão pode ser suspensa, e o tratamento retomado no dia seguinte. O sujeito só seria afastado da pesquisa se cinco sessões ao todo fossem suspensas ou se alguma intolerância do paciente o impedisse de continuar o tratamento. Os pais e responsáveis também poderiam parar o tratamento em qualquer fase se assim o desejassem. O procedimento é um ato médico podendo ser realizado somente sob a presença de profissional treinado e qualificado. Assim, qualquer eventual alteração clínica receberia a intervenção imediata de profissional especializado.

A fase 4 acontece após a última sessão de Estimulação Magnética Transcraniana. Os sujeitos passam novamente pelos testes de função executiva WSCT e STROOP test e os pais e cuidadores respondem as escalas Y-BOX e RBS. Os testes e escalas são aplicados pelos mesmos profissionais que aplicaram os questionários na fase 2. Esses profissionais não tiveram contato com os pacientes ou a equipe durante o tratamento. As variáveis formatadas nessa fase serviram de base para comparação com as formatadas na fase 2 e, assim, pôde-se analisar as mudanças ocorridas após o procedimento.

Numa quinta fase, os pacientes refazem os testes após três meses do procedimento de EMT. O objetivo da fase 5 é analisar os efeitos tardios do procedimento. Por ter sido utilizado um protocolo de Theta Burst, os resultados devem mostrar efeitos a longo prazo. Tanto os testes aplicados aos pais Y-BOCS e RBS, quanto os testes neuropsicológicos aplicados aos indivíduos tratados com EMT WSCT w STROOP test foram realizados.

\subsection{Análise Estatística}

Por se tratar de um estudo experimental e, portanto, com um número restrito de sujeitos $(\mathrm{n}=11)$, os dados são apresentados de início individualmente. Análises qualitativas individuais de cada variável foram feitas e as mudanças demonstradas através da comparação das medianas e desvios padrão. Em seguida, foi realizado o 
teste $\mathrm{T}$ pareado a fim de se avaliar a mudança de cada variável antes e depois do procedimento de Estimulação Magnética Transcraniana. Para correlacionar os padrões de mudanças, recorreu-se ao teste de Spearman. As variações apresentadas foram comparadas em diferentes grupos: as diferenças das respostas nos pacientes com Autismo e com Síndrome de Asperger, segundo a idade doe início da linguagem e do padrão cognitivo.

\subsection{Cronograma dos procedimentos}

\begin{tabular}{|c|c|c|c|c|}
\hline Fase 1 & Fase 2 & Fase 3 & Fase 4 & Fase 5 \\
\hline Avaliação Clínica & Y-BOX & EMT & Y-BOX & Y-BOCS \\
(CID-10) & RBS & & RBS & RBS \\
WISC-III & WSCT & & WSCT & WSCT \\
K-SADS & STROOP test & & STROOP test & STROOP test \\
RNM crânio & & & & \\
EEG & & & & \\
WSCT & & & & \\
\hline
\end{tabular}

\subsection{Cronograma do estudo}

\begin{tabular}{|c|c|c|c|c|c|c|c|c|c|c|c|c|}
\hline A & $\mathbf{1}$ & $\mathbf{2}$ & $\mathbf{3}$ & $\mathbf{4}$ & $\mathbf{5}$ & $\mathbf{6}$ & $\mathbf{7}$ & $\mathbf{8}$ & $\mathbf{9}$ & $\mathbf{1 0}$ & $\mathbf{1 1}$ & $\mathbf{1 2}$ \\
\hline B & X & X & X & X & X & X & X & X & X & X & & \\
\hline C & & & X & X & X & X & X & X & & & & \\
\hline D & & & & X & X & X & X & & & & & \\
\hline E & & & & X & X & X & X & X & X & & & \\
\hline F & & & & & & & & & X & X & & \\
\hline G & & & & & & & & & & & X & \\
\hline H & & & & & & & & & & & & X \\
\hline
\end{tabular}
A: Período de dois meses.
B: Revisão bibliográfica.
C: Coleta de dados.
D: Aplicação da EMT.
E: Transcrição dos dados colhidos.
F: Análise dos dados colhidos.
G: Redação final da tese.
H: Período máximo de finalização da tese. 
5 Aspectos éticos da pesquisa 
Os sujeitos selecionados pelo presente estudo foram convidados a participar do projeto, por meio de seus pais ou responsáveis, após o diagnóstico de Autismo. O Termo de consentimento livre e esclarecido (TCLE) foi apresentado e detalhado pelos pesquisadores aos pais e responsáveis em razão de os participantes serem considerados vulneráveis, pois a patologia estudada é crônica com impacto na vida funcional.

A participação dos pacientes neste estudo trouxe como beneficio o esclarecimento diagnóstico para a família e para o indivíduo e a hipótese de melhora dos sintomas relacionados ao comportamento restrito e repetitivo.

Não houve riscos durante o processo de avaliação. A Estimulação Magnética Transcraniana (EMT) não gera dor e pode ser realizada em qualquer indivíduo. Um desconforto mínimo ocorre por um ruído de baixa intensidade no momento do procedimento e para amenizá-lo disponibilizam-se, se necessário, os protetores auriculares.

A duração desse procedimento foi de no máximo 5 minutos por sessão, não necessitando de sedação. Foram realizadas quinze sessões em quinze dias úteis. O paciente ficou acordado o tempo todo durante o procedimento e pôde ser acompanhado por seu responsável sem risco previsível para ambos. O campo magnético é pontual, não trazendo nenhum prejuízo para o médico avaliador, ou paciente. Os dados obtidos são sigilosos e os pacientes serão citados de forma anônima. 


\section{Resultados}


Dos 13 pacientes que tiveram o Termo de Consentimento Livre e Esclarecido assinado para participar da pesquisa , 11 terminaram todas as fases propostas pelo estudo. Um dos pacientes afastados foi encaminhado para tratamento de uma massa tumoral encontrada no exame de Ressonância Magnética de Crânio durante a triagem diagnóstica. O outro foi afastado por não conseguir permanecer sentado, pela agitação psicomotora, para realizar o tratamento no primeiro dia de sessão da Estimulação Magnética Transcraniana.

A distribuição das idades dos 11 sujeitos escolhidos era de 9 a 17 anos (Tabela 1). $45 \%$ dos pacientes tinham menos de 12 anos de idade e 55\% estavam acima desse limite.

Tabela 1 - Frequências das Idades dos Sujeitos

\begin{tabular}{ccccc}
\hline \hline Idade & Frequência & $\begin{array}{c}\text { Percentual } \\
(\mathbf{\%})\end{array}$ & $\begin{array}{c}\text { Percentual Válido } \\
(\mathbf{\%})\end{array}$ & $\begin{array}{c}\text { Percentual } \\
\text { Cumulativo (\%) }\end{array}$ \\
\hline $\mathbf{9}$ & 2 & 18.2 & 18.2 & 18.2 \\
$\mathbf{1 0}$ & 1 & 9.1 & 9.1 & 27.3 \\
$\mathbf{1 1}$ & 1 & 9.1 & 9.1 & 36.4 \\
$\mathbf{1 2}$ & 1 & 9.1 & 9.1 & 45.5 \\
$\mathbf{1 3}$ & 2 & 18.2 & 18.2 & 63.6 \\
$\mathbf{1 4}$ & 2 & 18.2 & 18.2 & 81.8 \\
$\mathbf{1 6}$ & 1 & 9.1 & 9.1 & 90.9 \\
$\mathbf{1 7}$ & 1 & 9.1 & 9.1 & 100 \\
\hline Total & 11 & 100 & 100 & \\
\hline
\end{tabular}

Um indivíduo selecionado para o experimento, embora não apresentasse critério cognitivo de coeficiente de inteligência acima de 75 (Tabela 2), foi incluído no protocolo, por se tratar de um paciente com boa funcionalidade e independência, com dificuldade expressiva vinculada exclusivamente ao comportamento restrito e repetitivo de alto impacto. ,. Em todos os sujeitos que cumpriram todo protocolo, foram 
encontradas discrepâncias entre coeficientes de inteligência executiva e verbal. Os pacientes apresentavam uma função cognitiva executiva superior à verbal (Tabela 3 e 4).

Tabela 2 - Frequência dos Coeficientes de Inteligência (QI) pelo WISC III

\begin{tabular}{ccccc}
\hline \hline QI & Frequência & $\begin{array}{c}\text { Percentual } \\
(\boldsymbol{\%})\end{array}$ & $\begin{array}{c}\text { Percentual Valido } \\
(\boldsymbol{\%})\end{array}$ & $\begin{array}{c}\text { Percentual } \\
\text { Cumulativo (\%) }\end{array}$ \\
\hline $\mathbf{5 1}$ & 1 & 9.1 & 9.1 & 9.1 \\
$\mathbf{7 6}$ & 1 & 9.1 & 9.1 & 18.2 \\
$\mathbf{8 7}$ & 1 & 9.1 & 9.1 & 27.3 \\
$\mathbf{9 1}$ & 1 & 9.1 & 9.1 & 36.4 \\
$\mathbf{9 4}$ & 1 & 9.1 & 9.1 & 45.5 \\
$\mathbf{9 8}$ & 2 & 18.2 & 18.2 & 63.6 \\
$\mathbf{9 9}$ & 1 & 9.1 & 9.1 & 72.7 \\
$\mathbf{1 0 2}$ & 1 & 9.1 & 9.1 & 81.8 \\
$\mathbf{1 1 4}$ & 1 & 9.1 & 9.1 & 90.9 \\
\hline $\mathbf{1 2 0}$ & 1 & 9.1 & 91 & 100.0 \\
\hline Total & 11 & 100.0 & 100.0 & \\
\hline QI-Coeficiente de Inteligência; \\
WISC III - Escala de Inteligência Wechsler para Crianças - terceira edição &
\end{tabular}

Tabela 3 - Coeficiente de Inteligência de Execução (QIe) pelo WISC III

\begin{tabular}{ccccc}
\hline QIe & Frequência & $\begin{array}{c}\text { Percentual } \\
(\boldsymbol{\%})\end{array}$ & $\begin{array}{c}\text { Percentual Valido } \\
(\boldsymbol{\%})\end{array}$ & $\begin{array}{c}\text { Percentual } \\
\text { Cumulativo (\%) }\end{array}$ \\
\hline $\mathbf{5 7}$ & 1 & 9.1 & 9.1 & 9.1 \\
$\mathbf{8 5}$ & 1 & 9.1 & 9.1 & 18.2 \\
$\mathbf{8 7}$ & 1 & 9.1 & 9.1 & 27.3 \\
$\mathbf{9 8}$ & 1 & 9.1 & 9.1 & 36.4 \\
$\mathbf{9 9}$ & 1 & 9.1 & 9.1 & 45.5 \\
$\mathbf{1 0 8}$ & 1 & 9.1 & 9.1 & 54.5 \\
$\mathbf{1 1 3}$ & 1 & 9.1 & 9.1 & 63.6 \\
$\mathbf{1 1 5}$ & 1 & 9.1 & 9.1 & 72.7 \\
$\mathbf{1 1 8}$ & 1 & 9.1 & 9.1 & 81.8 \\
$\mathbf{1 2 1}$ & 1 & 9.1 & 9.1 & 90.9 \\
$\mathbf{1 2 8}$ & 1 & 9.1 & 9.1 & 100.0 \\
Total & 11 & 100 & 100 & \\
\hline
\end{tabular}

QIe - Coeficiente de Inteligência de Execução;

WISC III - Escala de Inteligência Wechsler para Crianças - terceira edição 
Tabela 4 - Coeficiente de Inteligência Verbal (QIv) pelo WISC III

\begin{tabular}{ccccc}
\hline QIv & Frequência & $\begin{array}{c}\text { Percentual } \\
(\boldsymbol{\%})\end{array}$ & $\begin{array}{c}\text { Percentual Valido } \\
(\boldsymbol{\%})\end{array}$ & $\begin{array}{c}\text { Percentual } \\
\text { Cumulativo (\%) }\end{array}$ \\
\hline $\mathbf{5 3}$ & 1 & 9.1 & 9.1 & 9.1 \\
$\mathbf{7 0}$ & 1 & 9.1 & 9.1 & 18.2 \\
$\mathbf{7 6}$ & 1 & 9.1 & 9.1 & 27.3 \\
$\mathbf{7 9}$ & 1 & 9.1 & 9.1 & 36.4 \\
$\mathbf{8 2}$ & 1 & 9.1 & 9.1 & 45.5 \\
$\mathbf{8 3}$ & 1 & 9.1 & 9.1 & 54.5 \\
$\mathbf{1 0 2}$ & 1 & 9.1 & 9.1 & 63.6 \\
$\mathbf{1 0 5}$ & 1 & 9.1 & 9.1 & 72.7 \\
$\mathbf{1 0 6}$ & 1 & 9.1 & 9.1 & 81.8 \\
$\mathbf{1 1 2}$ & 1 & 9.1 & 9.1 & 90.9 \\
$\mathbf{1 1 6}$ & 1 & 9.1 & 9.1 & 100.0 \\
Total & 11 & 100 & 100 & \\
\hline
\end{tabular}

QIv - Coeficiente de Inteligência verbal;

WISC III - Escala de Inteligência Wechsler para Crianças - terceira edição;

Pelo bom padrão cognitivo, os pacientes apresentaram escolaridade bem próxima do nível de desenvolvimento considerado típico (Tabela 5). A exceção relaciona-se ao paciente mais velho (17a) que não terminou ainda o ensino médio e está afastado da escola, não por problemas acadêmicos, e sim por apresentar sintomas de inflexibilidade que não o permitem tolerar as responsabilidades e a complexibilidade das relações sociais. Quanto ao nível socioeconômico temos representações dos níveis $\mathrm{A} 1$ ao $\mathrm{C} 1$ representados na Tabela 6.

Tabela 5 - Frequência da escolaridade entre os sujeitos

\begin{tabular}{lcccc}
\hline \hline Escolaridade & $\begin{array}{c}\text { Frequênci } \\
\text { a }\end{array}$ & $\begin{array}{c}\text { Percentual } \\
(\boldsymbol{\%})\end{array}$ & $\begin{array}{c}\text { Percentual } \\
\text { Valido (\%) }\end{array}$ & $\begin{array}{c}\text { Percentual } \\
\text { Cumulativo (\%) }\end{array}$ \\
\hline $\begin{array}{l}\mathbf{2}^{\mathbf{0}} \text { grau } \\
\text { compl. }\end{array}$ & 1 & 9.1 & 9.1 & 9.1 \\
\hline $\mathbf{1}^{\mathbf{0}}$ ano médio & 2 & 18.2 & 18.2 & 27.3 \\
$\mathbf{8}^{\mathbf{0}}$ ano fund. & 1 & 9.1 & 9.1 & 36.4 \\
$\mathbf{7}^{\mathbf{0}}$ ano fund. & 1 & 9.1 & 9.1 & 45.5 \\
$\mathbf{5}^{\mathbf{0}}$ ano fund. & 5 & 45.5 & 45.5 & 91 \\
\hline $\mathbf{2}^{\mathbf{o}}$ ano fund. & 1 & 9.1 & 9.1 & 100 \\
\hline Total & 11 & 100 & 100 & \\
\hline
\end{tabular}


Tabela 6 - Frequência do nível socioeconômicos dos sujeitos

\begin{tabular}{ccccc}
\hline \hline Socioeconômico & Frequência & $\begin{array}{c}\text { Percentual } \\
(\boldsymbol{\%})\end{array}$ & $\begin{array}{c}\text { Percentual } \\
\text { Válido }(\boldsymbol{\%})\end{array}$ & $\begin{array}{c}\text { Percentual } \\
\text { Cumulativo (\%) }\end{array}$ \\
\hline A1 & 1 & 9.1 & 9.1 & 9.1 \\
A2 & 3 & 27.3 & 27.3 & 36.4 \\
B1 & 2 & 18.2 & 18.2 & 54.5 \\
B2 & 3 & 27.3 & 27.3 & 81.8 \\
C1 & 2 & 18.2 & 18.2 & 100 \\
Total & 11 & 100 & 100 & \\
\hline
\end{tabular}

Os sujeitos foram divididos em dois grupos diagnósticos distintos. Cinco pacientes com Síndrome de Asperger e seis pacientes Autistas (Tabela 7). Basicamente, a diferença entre ambos está no atraso no desenvolvimento da linguagem por parte do grupo dos Autistas, fator que se mostrou relevante na resposta terapêutica dos pacientes ao tratamento de Estimulação Magnética Transcraniana (Gráficos 19 e 20). A idade do início do desenvolvimento da linguagem dos sujeitos variou de 9 meses aos 48 meses (Tabela 8). Outra diferença entre esses grupos está no padrão cognitivo. Os pacientes com Síndrome de Asperger têm necessariamente um padrão cognitivo na média ou acima dela. Os pacientes com Autismo podem ter qualquer nível cognitivo, por vezes apresentando deficiência intelectual em sua forma severa. No caso do presente estudo, por haver um corte no nível cognitivo justamente no limite da normalidade como critério de exclusão, o único paciente influenciado pelo fator cognitivo para o diagnóstico foi o sujeito que possui o coeficiente de inteligência 52, incluído no estudo como uma proposta experimental.

Tabela 7 - Frequência por diagnóstico

\begin{tabular}{ccccc}
\hline \hline Diagnóstico & Frequência & $\begin{array}{c}\text { Percentual } \\
(\boldsymbol{\%})\end{array}$ & $\begin{array}{c}\text { Percentual Válido } \\
(\boldsymbol{\%})\end{array}$ & $\begin{array}{c}\text { Percentual } \\
\text { Cumulativo (\%) }\end{array}$ \\
\hline Autismo & 6 & 54.5 & 54.5 & 54.5 \\
$\begin{array}{c}\text { Sd. } \\
\text { Asperger }\end{array}$ & 5 & 45.5 & 45.5 & 45.5 \\
Total & 11 & 100 & 100 & 100 \\
\hline
\end{tabular}


Tabela 8 - Frequência das Idades de Início do desenvolvimento da linguagem nos sujeitos

\begin{tabular}{ccccc}
\hline $\begin{array}{c}\text { Idade em } \\
\text { meses }\end{array}$ & Frequência & $\begin{array}{c}\text { Percentual } \\
(\mathbf{\%})\end{array}$ & $\begin{array}{c}\text { Percentual Válido } \\
(\mathbf{\%})\end{array}$ & $\begin{array}{c}\text { Percentual } \\
\text { Cumulativo (\%) }\end{array}$ \\
\hline $\mathbf{9}$ & 1 & 9.1 & 9.1 & 9.1 \\
$\mathbf{1 2}$ & 1 & 9.1 & 9.1 & 18.2 \\
$\mathbf{1 4}$ & 1 & 9.1 & 9.1 & 27.3 \\
$\mathbf{1 8}$ & 3 & 27.3 & 27.3 & 54.5 \\
$\mathbf{2 4}$ & 1 & 9.1 & 9.1 & 63.6 \\
$\mathbf{3 6}$ & 2 & 18.2 & 18.2 & 81.8 \\
$\mathbf{6 0}$ & 2 & 18.2 & 18.2 & 100 \\
\hline Total & 11 & 100 & 100 & \\
\hline
\end{tabular}

Quanto ao uso de medicamentos durante o período em que estavam inseridos no protocolo de tratamento, 6 indivíduos não faziam uso de medicações e 5 estavam em uso das medicações, descritas na Tabela 9. Não ocorreu nenhuma mudança nas dosagens e frequência de uso de nenhum medicamento durante o protocolo de tratamento.

Tabela 9 - Frequência das medicações usadas pelos pacientes durante o protocolo de EMT

\begin{tabular}{ccccc}
\hline \hline Medicação & Frequência & $\begin{array}{c}\text { Percentual } \\
(\boldsymbol{\%})\end{array}$ & $\begin{array}{c}\text { Percentual } \\
\text { Valido (\%) }\end{array}$ & $\begin{array}{c}\text { Percentual } \\
\text { Cumulativo (\%) }\end{array}$ \\
\hline Sem & 6 & 54.5 & 54.5 & 54.5 \\
\hline Aripiprazol & 1 & 9.1 & 9.1 & 63.6 \\
$\begin{array}{c}\text { Aripiprazol } \\
\text { Clomipramina }\end{array}$ & 1 & 9.1 & 9.1 & 72.7 \\
$\begin{array}{c}\text { Aripiprazol } \\
\text { Fluoxetina }\end{array}$ & 1 & 9.1 & 9.1 & 81.8 \\
Metilfenidato & & 9.1 & 9.1 & 90.9 \\
$\begin{array}{c}\text { Quetiapina } \\
\text { Olanzapina } \\
\text { Topiramato }\end{array}$ & 1 & 9.1 & 9.1 & 100.0 \\
\hline Total & 11 & 100.0 & 100.0 & \\
\hline EMT - Estimulac̃o Magnética Transcraniana & & & \\
\hline
\end{tabular}


As variáveis numéricas dos testes aplicados antes e depois do protocolo de Estimulação Magnética Transcraniana, que se mostraram importantes para análise estatística, estão descritas abaixo (Tabela 10). As variáveis sinalizadas como "pré”, após sua especificação, correspondem àquelas colhidas antes do início do tratamento com a Estimulação e as sinalizadas como "pós", àquelas colhidas após o procedimento.

Tabela 10 - Análise da estatística dos Descritores

\begin{tabular}{|c|c|c|c|c|}
\hline \multicolumn{3}{|l|}{ Variável } & Estatística & $\begin{array}{c}\text { Erro } \\
\text { Padrão } \\
\end{array}$ \\
\hline \multirow{13}{*}{$\begin{array}{l}\text { Escore total de } \\
\text { Compulsões pelo } \\
\text { Y-BOCS - pré }\end{array}$} & \multicolumn{2}{|l|}{ Média } & 11,55 & 1,755 \\
\hline & \multirow{2}{*}{$\begin{array}{l}95 \% \text { Intervalo de } \\
\text { Confiança para a Média }\end{array}$} & Limite Superior & 7,64 & \\
\hline & & Limite Superior & 15,46 & \\
\hline & \multicolumn{2}{|l|}{ 5\% de Média Aparada } & 11,77 & \\
\hline & \multicolumn{2}{|l|}{ Mediana } & 13,00 & \\
\hline & \multicolumn{2}{|l|}{ Variância } & 33,873 & \\
\hline & \multicolumn{2}{|l|}{ Desvio Padrão } & 5,820 & \\
\hline & \multicolumn{2}{|l|}{ Minimo } & 0 & \\
\hline & \multicolumn{2}{|l|}{ Máximo } & 19 & \\
\hline & \multicolumn{2}{|l|}{ Alcance } & 19 & \\
\hline & \multicolumn{2}{|l|}{ Intervalo interquartile } & 7 & \\
\hline & \multicolumn{2}{|l|}{ Assimetria } &,- 921 & ,661 \\
\hline & \multicolumn{2}{|l|}{ Kurtosis } &, 221 & 1,279 \\
\hline \multirow{13}{*}{$\begin{array}{l}\text { Apanhado Geral dos } \\
\text { Escores RBS - pré }\end{array}$} & \multicolumn{2}{|l|}{ Média } & 27,27 & 4,716 \\
\hline & \multirow{2}{*}{$\begin{array}{l}\text { 95\% Intervalo de } \\
\text { Confiança para a Média }\end{array}$} & Limite Superior & 16,77 & \\
\hline & & Limite Superior & 37,78 & \\
\hline & \multicolumn{2}{|l|}{$5 \%$ de Média Aparada } & 26,91 & \\
\hline & \multicolumn{2}{|l|}{ Mediana } & 24,00 & \\
\hline & \multicolumn{2}{|l|}{ Variância } & 244,618 & \\
\hline & \multicolumn{2}{|l|}{ Desvio Padrão } & 15,640 & \\
\hline & \multicolumn{2}{|l|}{ Minimo } & 9 & \\
\hline & \multicolumn{2}{|l|}{ Máximo } & 52 & \\
\hline & \multicolumn{2}{|l|}{ Alcance } & 43 & \\
\hline & \multicolumn{2}{|l|}{ Intervalo interquartile } & 34 & \\
\hline & \multicolumn{2}{|l|}{ Assimetria } &, 528 & ,661 \\
\hline & \multicolumn{2}{|l|}{ Kurtosis } & $-1,186$ & 1,279 \\
\hline
\end{tabular}

Continua... 
Continuação Tabela 10

\begin{tabular}{|c|c|c|c|c|}
\hline \multicolumn{3}{|l|}{ Variável } & \multirow{3}{*}{$\begin{array}{r}\text { Estatística } \\
, 475831 \\
, 332255\end{array}$} & \multirow{2}{*}{$\begin{array}{c}\begin{array}{c}\text { Erro } \\
\text { Padrão }\end{array} \\
, 0644377 \\
\end{array}$} \\
\hline \multirow{13}{*}{$\begin{array}{l}\text { Percentual de Erros } \\
\text { no WSCT - pré }\end{array}$} & \multicolumn{2}{|l|}{ Média } & & \\
\hline & \multirow{2}{*}{$\begin{array}{l}95 \% \text { Intervalo de } \\
\text { Confiança para a Média }\end{array}$} & Limite Superior & & \\
\hline & & Limite Superior & ,619407 & \\
\hline & \multicolumn{2}{|l|}{ 5\% de Média Aparada } &, 481829 & \\
\hline & \multicolumn{2}{|l|}{ Mediana } & ,546870 & \\
\hline & \multicolumn{2}{|l|}{ Variância } &, 046 & \\
\hline & \multicolumn{2}{|l|}{ Desvio Padrão } & ,2137156 & \\
\hline & \multicolumn{2}{|l|}{ Minimo } & ,0937 & \\
\hline & \multicolumn{2}{|l|}{ Máximo } & ,7500 & \\
\hline & \multicolumn{2}{|l|}{ Alcance } &, 6563 & \\
\hline & \multicolumn{2}{|l|}{ Intervalo interquartile } &, 3750 & \\
\hline & \multicolumn{2}{|l|}{ Assimetria } &,- 456 & 661 \\
\hline & \multicolumn{2}{|l|}{ Kurtosis } &,- 936 & 1,279 \\
\hline \multirow{13}{*}{$\begin{array}{l}\text { Percentual de } \\
\text { respostas } \\
\text { perseverativa no } \\
\text { WSCT - pré }\end{array}$} & \multicolumn{2}{|l|}{ Média } & ,339475 & 0774127 \\
\hline & \multirow{2}{*}{$\begin{array}{l}95 \% \text { Intervalo de } \\
\text { Confiança para a Média }\end{array}$} & Limite Superior & ,166988 & \\
\hline & & Limite Superior & ,511961 & \\
\hline & \multicolumn{2}{|l|}{ 5\% de Média Aparada } & ,319902 & \\
\hline & \multicolumn{2}{|l|}{ Mediana } & ,250000 & \\
\hline & \multicolumn{2}{|l|}{ Variância } &, 066 & \\
\hline & \multicolumn{2}{|l|}{ Desvio Padrão } & ,2567489 & \\
\hline & \multicolumn{2}{|l|}{ Minimo } &, 0625 & \\
\hline & \multicolumn{2}{|l|}{ Máximo } & ,9688 & \\
\hline & \multicolumn{2}{|l|}{ Alcance } & ,9063 & \\
\hline & \multicolumn{2}{|l|}{ Intervalo interquartile } & ,3437 & \\
\hline & Assimetria & & 1,567 &, 661 \\
\hline & Kurtosis & & 2,924 & 1,279 \\
\hline Percentual de erros & Média & & ,286914 &, 0577102 \\
\hline perseverativos no & $95 \%$ Intervalo de & Limite Superior & , 158327 & \\
\hline & Confiança para a Média & Limite Superior & ,415500 & \\
\hline & 5\% de Média Aparada & & ,275390 & \\
\hline & Mediana & & 234300 & \\
\hline & Variância & &, 037 & \\
\hline & Desvio Padrão & &, 1914030 & \\
\hline & Minimo & &, 0625 & \\
\hline & Máximo & &, 7188 & \\
\hline & Alcance & &, 6563 & \\
\hline & Intervalo interquartile & &, 2813 & \\
\hline & Assimetria & & 1,169 &, 661 \\
\hline & Kurtosis & & 1,331 & 1,279 \\
\hline
\end{tabular}

Continua... 
Continuação Tabela 10

\begin{tabular}{|c|c|c|c|c|}
\hline \multicolumn{3}{|l|}{ Variável } & \multirow{2}{*}{$\begin{array}{r}\text { Estatística } \\
, 240047\end{array}$} & \multirow{2}{*}{$\begin{array}{c}\begin{array}{c}\text { Erro } \\
\text { Padrão }\end{array} \\
, 0413546\end{array}$} \\
\hline \multirow{13}{*}{$\begin{array}{l}\text { Percentual de erros } \\
\text { não persevertivos no } \\
\text { WSCT - pré }\end{array}$} & \multicolumn{2}{|l|}{ Média } & & \\
\hline & \multirow{2}{*}{$\begin{array}{l}95 \% \text { Intervalo de } \\
\text { Confiança para a Média }\end{array}$} & Limite Superior & 147903 & \\
\hline & & Limite Superior & ,332191 & \\
\hline & \multicolumn{2}{|l|}{$5 \%$ de Média Aparada } & ,238075 & \\
\hline & \multicolumn{2}{|l|}{ Mediana } & ,250000 & \\
\hline & \multicolumn{2}{|l|}{ Variância } & 019 & \\
\hline & \multicolumn{2}{|l|}{ Desvio Padrão } & , 1371577 & \\
\hline & \multicolumn{2}{|l|}{ Minimo } &, 0625 & \\
\hline & \multicolumn{2}{|l|}{ Máximo } & ,4531 & \\
\hline & \multicolumn{2}{|l|}{ Alcance } & ,3906 & \\
\hline & \multicolumn{2}{|l|}{ Intervalo interquartile } & ,2031 & \\
\hline & \multicolumn{2}{|l|}{ Assimetria } & ,271 & ,661 \\
\hline & \multicolumn{2}{|l|}{ Kurtosis } & $-1,264$ & 1,279 \\
\hline \multirow{13}{*}{$\begin{array}{l}\text { Percentual de } \\
\text { respostas em nível } \\
\text { conceitual - pré }\end{array}$} & \multicolumn{2}{|l|}{ Média } & ,372148 &, 0818148 \\
\hline & \multirow{2}{*}{$\begin{array}{l}95 \% \text { Intervalo de } \\
\text { Confiança para a Média }\end{array}$} & Limite Superior & , 189853 & \\
\hline & & Limite Superior &, 554442 & \\
\hline & \multicolumn{2}{|l|}{ 5\% de Média Aparada } & ,364022 & \\
\hline & \multicolumn{2}{|l|}{ Mediana } &, 312500 & \\
\hline & \multicolumn{2}{|l|}{ Variância } &, 074 & \\
\hline & \multicolumn{2}{|l|}{ Desvio Padrão } & ,2713488 & \\
\hline & \multicolumn{2}{|l|}{ Minimo } & ,0468 & \\
\hline & \multicolumn{2}{|l|}{ Máximo } &, 8438 & \\
\hline & \multicolumn{2}{|l|}{ Alcance } & ,7970 & \\
\hline & \multicolumn{2}{|l|}{ Intervalo interquartile } & ,5313 & \\
\hline & Assimetria & & ,316 & ,661 \\
\hline & Kurtosis & & $-1,142$ & 1,279 \\
\hline Total de tempo & Média & & 25290,45 & 2800,274 \\
\hline (cent. seg.) no & $95 \%$ Intervalo de & Limite Superior & 19051,05 & \\
\hline pré & Confiança para a Média & Limite Superior & 31529,85 & \\
\hline & 5\% de Média Aparada & & 24793,39 & \\
\hline & Mediana & & 21400,00 & \\
\hline & Variância & & $8,626 \mathrm{E} 7$ & \\
\hline & Desvio Padrão & & 9287,459 & \\
\hline & Minimo & & 13100 & \\
\hline & Máximo & & 46428 & \\
\hline & Alcance & & 33328 & \\
\hline & Intervalo interquartile & & 12422 & \\
\hline & Assimetria & & 1,190 & ,661 \\
\hline & Kurtosis & & 1,549 & 1,279 \\
\hline
\end{tabular}

Continua... 
Continuação Tabela 10

\begin{tabular}{|c|c|c|c|c|}
\hline \multicolumn{3}{|l|}{ Variável } & \multirow{2}{*}{$\begin{array}{r}\text { Estatística } \\
8,45\end{array}$} & \multirow{2}{*}{$\begin{array}{c}\begin{array}{c}\text { Erro } \\
\text { Padrão }\end{array} \\
1,540\end{array}$} \\
\hline \multirow{13}{*}{$\begin{array}{l}\text { Escore total de } \\
\text { Compulsões pelo Y- } \\
\text { BOCS - pós }\end{array}$} & \multicolumn{2}{|l|}{ Média } & & \\
\hline & \multirow{2}{*}{$\begin{array}{l}\text { 95\% Intervalo de } \\
\text { Confiança para a Média }\end{array}$} & Limite Superior & 5,02 & \\
\hline & & Limite Superior & 11,88 & \\
\hline & \multicolumn{2}{|l|}{ 5\% de Média Aparada } & 8,62 & \\
\hline & \multicolumn{2}{|l|}{ Mediana } & 10,00 & \\
\hline & \multicolumn{2}{|l|}{ Variância } & 26,073 & \\
\hline & \multicolumn{2}{|l|}{ Desvio Padrão } & 5,106 & \\
\hline & \multicolumn{2}{|l|}{ Minimo } & 0 & \\
\hline & \multicolumn{2}{|l|}{ Máximo } & 14 & \\
\hline & \multicolumn{2}{|l|}{ Alcance } & 14 & \\
\hline & \multicolumn{2}{|l|}{ Intervalo interquartile } & 10 & \\
\hline & \multicolumn{2}{|l|}{ Assimetria } &,- 449 & ,661 \\
\hline & \multicolumn{2}{|l|}{ Kurtosis } & $-1,493$ & 1,279 \\
\hline \multirow{13}{*}{$\begin{array}{l}\text { Apanhado Geral dos } \\
\text { Escores do RBS - } \\
\text { pós }\end{array}$} & \multicolumn{2}{|l|}{ Média } & 13,45 & 3,369 \\
\hline & \multirow{2}{*}{$\begin{array}{l}95 \% \text { Intervalo de } \\
\text { Confiança para a Média }\end{array}$} & Limite Superior & 5,95 & \\
\hline & & Limite Superior & 20,96 & \\
\hline & \multicolumn{2}{|l|}{ 5\% de Média Aparada } & 12,39 & \\
\hline & \multicolumn{2}{|l|}{ Mediana } & 7,00 & \\
\hline & \multicolumn{2}{|l|}{ Variância } & 124,873 & \\
\hline & \multicolumn{2}{|l|}{ Desvio Padrão } & 11,175 & \\
\hline & \multicolumn{2}{|l|}{ Minimo } & 5 & \\
\hline & \multicolumn{2}{|l|}{ Máximo } & 41 & \\
\hline & \multicolumn{2}{|l|}{ Alcance } & 36 & \\
\hline & \multicolumn{2}{|l|}{ Intervalo interquartile } & 15 & \\
\hline & Assimetria & & 1,690 & 661 \\
\hline & Kurtosis & & 2,979 & 1,279 \\
\hline Percentual de erros & Média & & ,386345 & ,0716058 \\
\hline no WSCT- pós & $95 \%$ Intervalo de & Limite Superior & ,226798 & \\
\hline & Confiança para a Média & Limite Superior & ,545893 & \\
\hline & 5\% de Média Aparada & & ,383267 & \\
\hline & Mediana & & ,328100 & \\
\hline & Variância & &, 056 & \\
\hline & Desvio Padrão & & ,2374894 & \\
\hline & Minimo & & ,0781 & \\
\hline & Máximo & &, 7500 & \\
\hline & Alcance & &, 6719 & \\
\hline & Intervalo interquartile & &, 5000 & \\
\hline & Assimetria & & ,518 & ,661 \\
\hline & Kurtosis & & $-1,163$ & 1,279 \\
\hline
\end{tabular}


Continuação Tabela 10

\begin{tabular}{|c|c|c|c|c|}
\hline \multicolumn{3}{|l|}{ Variável } & \multirow{2}{*}{$\begin{array}{r}\text { Estatística } \\
, 275559 \\
\end{array}$} & \multirow{2}{*}{$\begin{array}{c}\begin{array}{c}\text { Erro } \\
\text { Padrão }\end{array} \\
, 0858180\end{array}$} \\
\hline \multirow{13}{*}{$\begin{array}{l}\text { Percentual de } \\
\text { repostas } \\
\text { perseverativas no } \\
\text { WSCT - pós }\end{array}$} & \multicolumn{2}{|l|}{ Média } & & \\
\hline & \multirow{2}{*}{$\begin{array}{l}95 \% \text { Intervalo de } \\
\text { Confiança para a Média }\end{array}$} & Limite Superior &, 084345 & \\
\hline & & Limite Superior & ,466774 & \\
\hline & \multicolumn{2}{|l|}{ 5\% de Média Aparada } & ,248888 & \\
\hline & \multicolumn{2}{|l|}{ Mediana } &, 109375 & \\
\hline & \multicolumn{2}{|l|}{ Variância } &, 081 & \\
\hline & \multicolumn{2}{|l|}{ Desvio Padrão } &, 2846261 & \\
\hline & \multicolumn{2}{|l|}{ Minimo } &, 0625 & \\
\hline & \multicolumn{2}{|l|}{ Máximo } & ,9687 & \\
\hline & \multicolumn{2}{|l|}{ Alcance } & ,9062 & \\
\hline & \multicolumn{2}{|l|}{ Intervalo interquartile } & ,4219 & \\
\hline & \multicolumn{2}{|l|}{ Assimetria } & 1,677 & ,661 \\
\hline & \multicolumn{2}{|l|}{ Kurtosis } & 2,670 & 1,279 \\
\hline \multirow{13}{*}{$\begin{array}{l}\text { Percetual de erros } \\
\text { perseverativos no } \\
\text { WSCT - pós }\end{array}$} & \multicolumn{2}{|l|}{ Média } &, 221577 &, 0611607 \\
\hline & \multirow{2}{*}{$\begin{array}{l}95 \% \text { Intervalo de } \\
\text { Confiança para a Média }\end{array}$} & Limite Superior &, 085303 & \\
\hline & & Limite Superior & ,357852 & \\
\hline & \multicolumn{2}{|l|}{ 5\% de Média Aparada } & ,202797 & \\
\hline & \multicolumn{2}{|l|}{ Mediana } &, 109400 & \\
\hline & \multicolumn{2}{|l|}{ Variância } &, 041 & \\
\hline & \multicolumn{2}{|l|}{ Desvio Padrão } & ,2028470 & \\
\hline & \multicolumn{2}{|l|}{ Minimo } &, 0625 & \\
\hline & \multicolumn{2}{|l|}{ Máximo } &, 7187 & \\
\hline & \multicolumn{2}{|l|}{ Alcance } & ,6562 & \\
\hline & \multicolumn{2}{|l|}{ Intervalo interquartile } & ,2969 & \\
\hline & Assimetria & & 1,695 &, 661 \\
\hline & Kurtosis & & 2,831 & 1,279 \\
\hline Percentual de erros & Média & &, 169020 &, 0527932 \\
\hline não perseverativos & $95 \%$ Intervalo de & Limite Superior &, 051390 & \\
\hline 100 vise $1-$ pos & Confiança para a Média & Limite Superior & ,286650 & \\
\hline & 5\% de Média Aparada & &, 152211 & \\
\hline & Mediana & &, 109370 & \\
\hline & Variância & &, 031 & \\
\hline & Desvio Padrão & &, 1750951 & \\
\hline & Minimo & &, 0156 & \\
\hline & Máximo & &, 6250 & \\
\hline & Alcance & & ,6094 & \\
\hline & Intervalo interquartile & &, 1875 & \\
\hline & Assimetria & & 2,042 & ,661 \\
\hline & Kurtosis & & 4,576 & 1,279 \\
\hline
\end{tabular}

Continua... 
Conclusão Tabela 10

\begin{tabular}{|c|c|c|c|c|}
\hline \multicolumn{3}{|l|}{ Variável } & \multirow{2}{*}{$\begin{array}{r}\text { Estatística } \\
, 484352\end{array}$} & \multirow{2}{*}{$\begin{array}{c}\begin{array}{c}\text { Erro } \\
\text { Padrão }\end{array} \\
, 0920083\end{array}$} \\
\hline \multirow{13}{*}{$\begin{array}{l}\text { Percentual de } \\
\text { respostas de nível } \\
\text { conceitual - pós }\end{array}$} & \multicolumn{2}{|l|}{ Média } & & \\
\hline & \multirow{2}{*}{$\begin{array}{l}\text { 95\% Intervalo de } \\
\text { Confiança para a } \\
\text { Média }\end{array}$} & Limite Superior & ,279345 & \\
\hline & & Limite Superior & ,689359 & \\
\hline & \multicolumn{2}{|c|}{ 5\% de Média Aparada } & ,484358 & \\
\hline & \multicolumn{2}{|l|}{ Mediana } & ,593750 & \\
\hline & \multicolumn{2}{|l|}{ Variância } & ,093 & \\
\hline & \multicolumn{2}{|l|}{ Desvio Padrão } & ,3051569 & \\
\hline & \multicolumn{2}{|l|}{ Minimo } & ,0468 & \\
\hline & \multicolumn{2}{|l|}{ Máximo } & ,9218 & \\
\hline & \multicolumn{2}{|l|}{ Alcance } &, 8750 & \\
\hline & \multicolumn{2}{|c|}{ Intervalo interquartile } & ,6094 & \\
\hline & \multicolumn{2}{|l|}{ Assimetria } &,- 456 & ,661 \\
\hline & \multicolumn{2}{|l|}{ Kurtosis } & $-1,141$ & 1,279 \\
\hline \multirow{13}{*}{$\begin{array}{l}\text { Tempo total (cent } \\
\text { seg) para realizar o } \\
\text { STROOP - pós }\end{array}$} & \multicolumn{2}{|l|}{ Média } & 7612,36 & 722,679 \\
\hline & \multirow{2}{*}{$\begin{array}{l}\text { 95\% Intervalo de } \\
\text { Confiança para a } \\
\text { Média }\end{array}$} & Limite Superior & 6002,13 & \\
\hline & & Limite Superior & 9222,59 & \\
\hline & \multicolumn{2}{|c|}{$5 \%$ de Média Aparada } & 7595,13 & \\
\hline & \multicolumn{2}{|l|}{ Mediana } & 7965,00 & \\
\hline & \multicolumn{2}{|l|}{ Variância } & $\begin{array}{r}5744913,2 \\
55 \\
\end{array}$ & \\
\hline & \multicolumn{2}{|l|}{ Desvio Padrão } & 2396,855 & \\
\hline & \multicolumn{2}{|l|}{ Minimo } & 3770 & \\
\hline & \multicolumn{2}{|l|}{ Máximo } & 11765 & \\
\hline & \multicolumn{2}{|l|}{ Alcance } & 7995 & \\
\hline & \multicolumn{2}{|c|}{ Intervalo interquartile } & 4201 & \\
\hline & \multicolumn{2}{|c|}{ Assimetria } &, 131 & ,661 \\
\hline & \multicolumn{2}{|l|}{ Kurtosis } &,- 666 & 1,279 \\
\hline
\end{tabular}

Os sujeitos apresentaram mudanças no padrão dos comportamentos restritos e repetitivos com diminuição dos valores nas escalas de avaliação, aplicadas aos pais e responsáveis, Repetitive Behavior Scale $(p=0,002)$, (Gráfico 4, 5) e Yale Brown Obsessive and Compulsive Scale $(p=0,02)$, (Gráfico 1 e 2). O item que mostrou maior relevância de mudança pelo YBOCS foi a Resistência à Mudança $(p=0,040)$, (Gráfico 3). Como proposto pela literatura, dividiram-se os comportamentos analisados pelo RBS-r em três classes: comportamentos restritos e repetitivos de ordem inferior, de ordem superior e insistência na mesmice. As mudanças de cada 
um, individualmente, apresentaram curvas muito semelhantes com relevância estatística respectivamente de $(p=0,05), \quad(p=0,028)$ e $(p=0,014)$, (Gráfico 6). Em todos os critérios, observa-se manutenção das mudanças na avaliação tardia após três meses. Correlações entre as mudanças ocorridas foram encontradas entre os comportamentos de ordem superior e a insistência na mesmice $(r=0,044)$, e as mudanças ocorridas no Y-BOCS $(r=0,019)$.

Gráfico 1 - Análise qualitativa da comparação do Escore Total de Compulsões pelo YBOCS antes e depois do procedimento de EMT

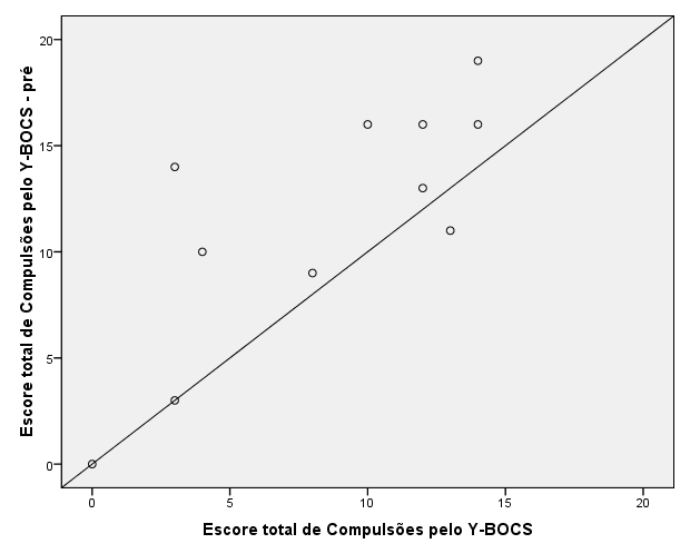

Gráfico 2 - Análise qualitativa da comparação das medianas do Escore Total de Compulsões pelo YBOCS nos três tempos após triagem

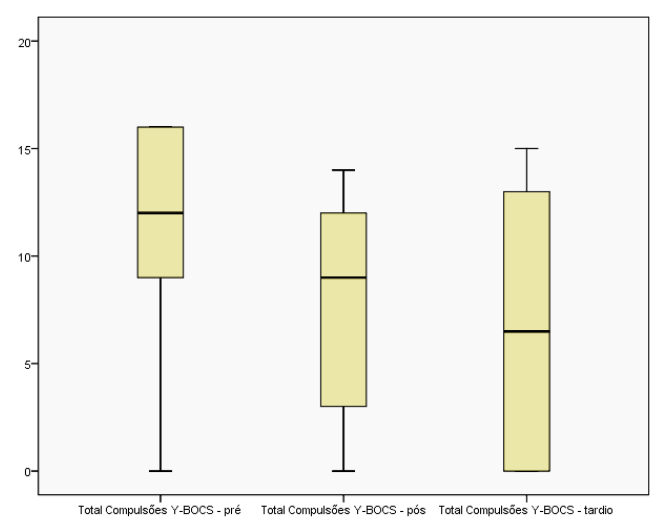

Gráfico 3 - Análise das Médias das Sub Escalas do YBOCS nos três tempos

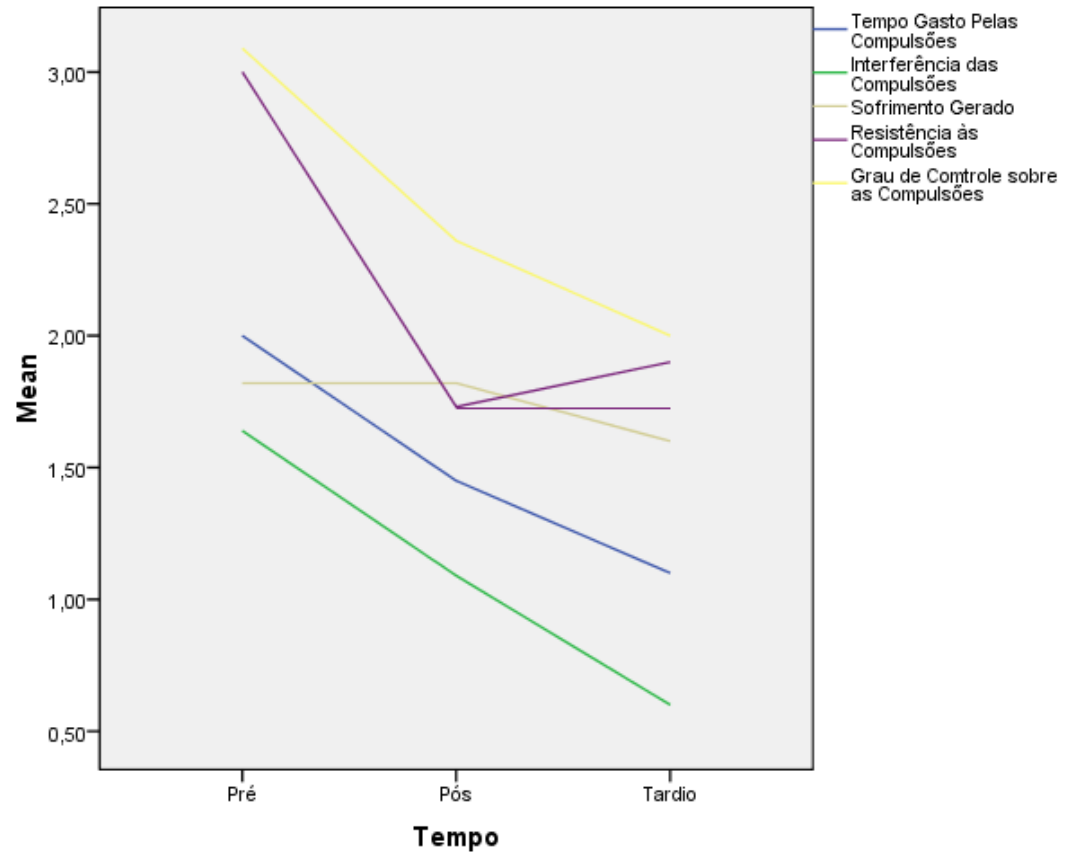




\begin{abstract}
Gráfico 4-Análise qualitativa da comparação do Apanhado Geral dos Escores do RBS antes e depois do procedimento de EMT
\end{abstract}

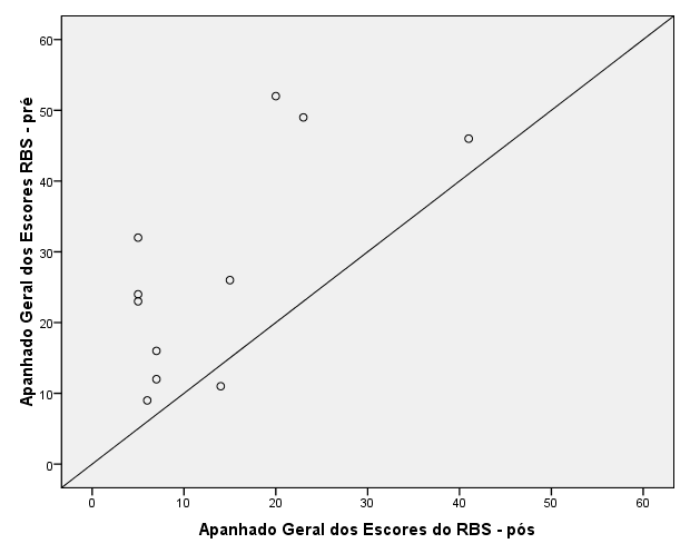

Gráfico 5 - Análise qualitativa da comparação das medianas do Apanhado Geral dos Escores do RBS nos três tempos após triagem

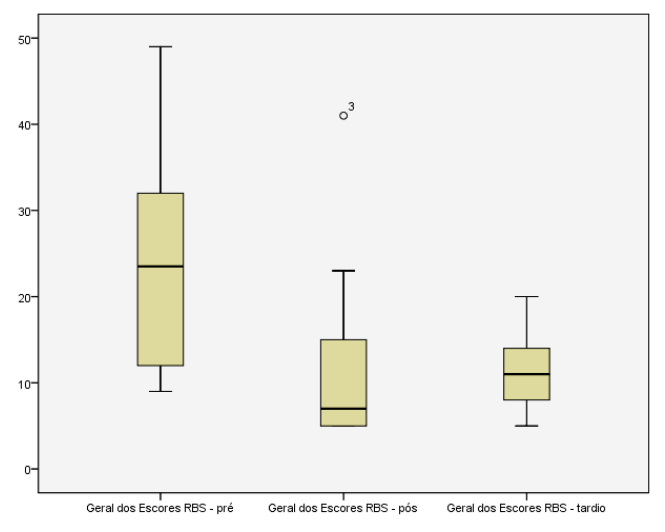

Gráfico 6 - Análise das Médias das entre às classes de CRR nos três tempos após triagem

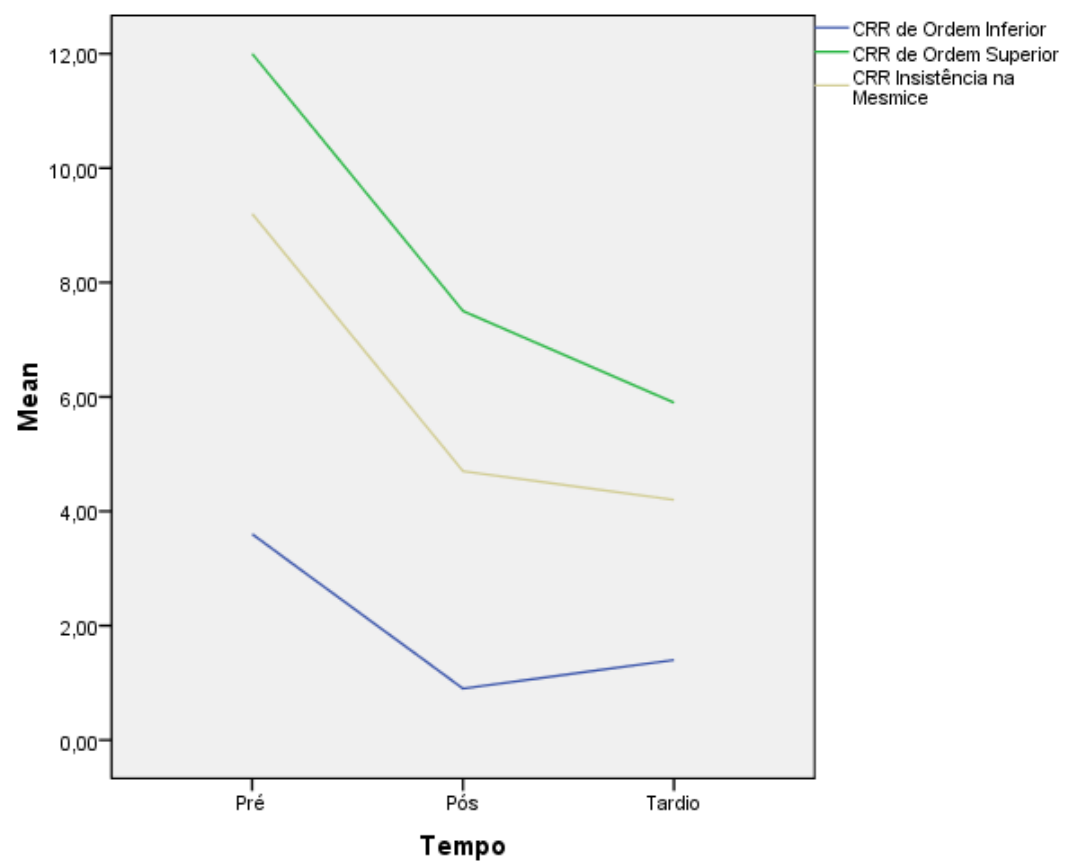

Quanto aos parâmetros neuropsicológicos aplicados diretamente aos sujeitos antes, depois e após três meses do procedimento, os parâmetros relacionados à inflexibilidade cognitiva e à velocidade do processamento de informações mostraram diferenças significativas. No Wisconsin Sort Card Test (WSCT), mudanças 
relevantes foram apresentadas no Total de Erros $(\mathrm{p}=0,037)$, (Gráficos 7 e 8), nas Respostas Perseverativas (Gráfico 9 e 10), no Número de Erros Perseverativos ( $\mathrm{p}=0,028),($ Gráficos 11 e 12), nos Erros Não Perseverativos (Graficos 13 e 14) e na Formação de Nível Conceitual ( $\mathrm{p}=0,022)$, (Gráficos 15 e 16) . Para o item Erros não Perseverativos, não ocorreram mudanças significativas. As mudanças apresentadas por todas as variáveis se mantiveram na avaliação tardia realizada após três meses do procedimento de EMT.

Gráfico 7 - Análise qualitativa da comparação do Total de Erros no WSCT antes e depois do procedimento de EMT

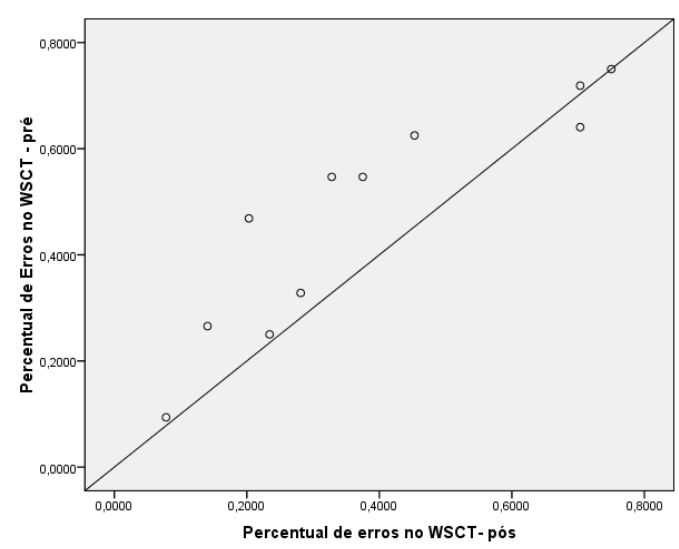

Gráfico 9- Análise qualitativa da comparação das Respostas Perseverativas no WSCT antes e depois do procedimento de EMT

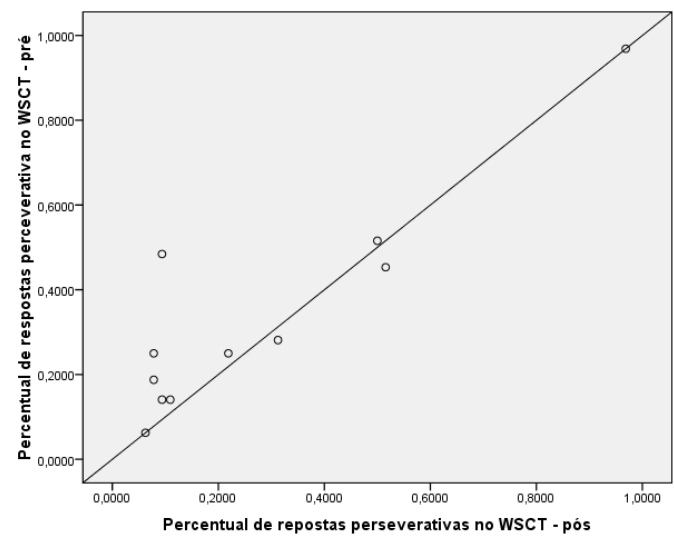

Gráfico 8 - Análise qualitativa da comparação das medianas do Total de Erros no WSCT nos quatro tempos

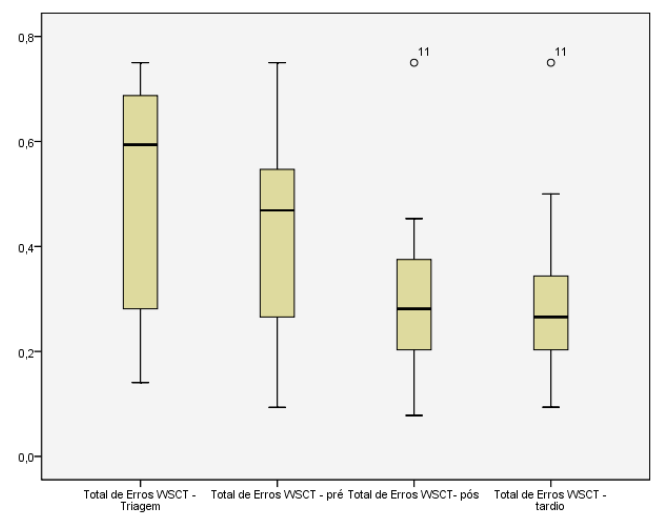

Gráfico 10 - Análise qualitativa da comparação das medianas Respostas Perseverativas no WSCT antes e depois do procedimento de EMT

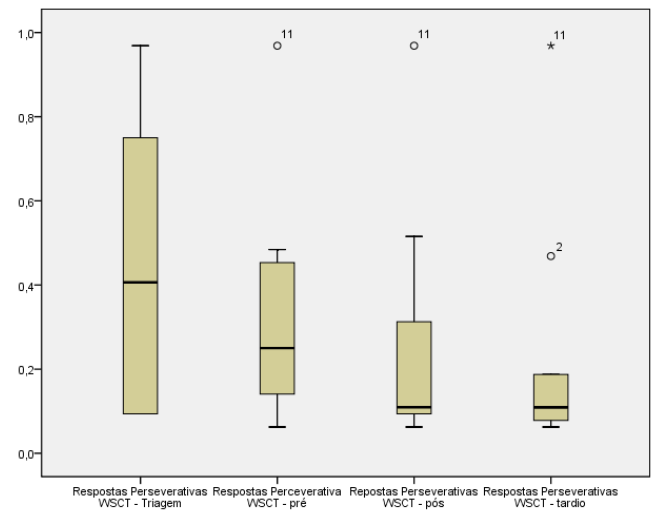


Gráfico 11 - Análise qualitativa da comparação dos Erros Perseverativos no WSCT antes e depois do procedimento de EMT

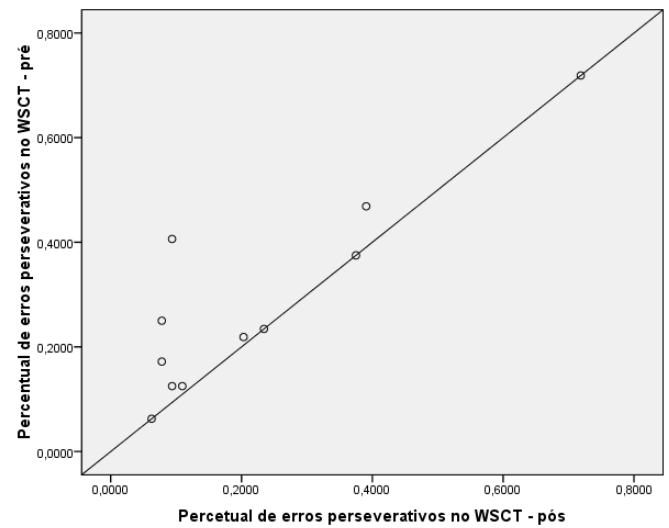

Gráfico 13 - Análise qualitativa da comparação dos Erros Não Perseverativos no WSCT antes e depois do procedimento de EMT

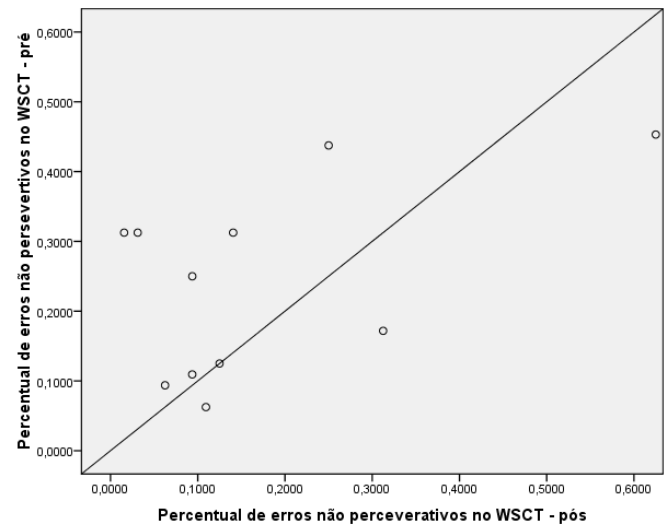

Gráfico 15 - Análise qualitativa da comparação da formação do Nível Conceitual no WSCT antes e depois do procedimento de EMT

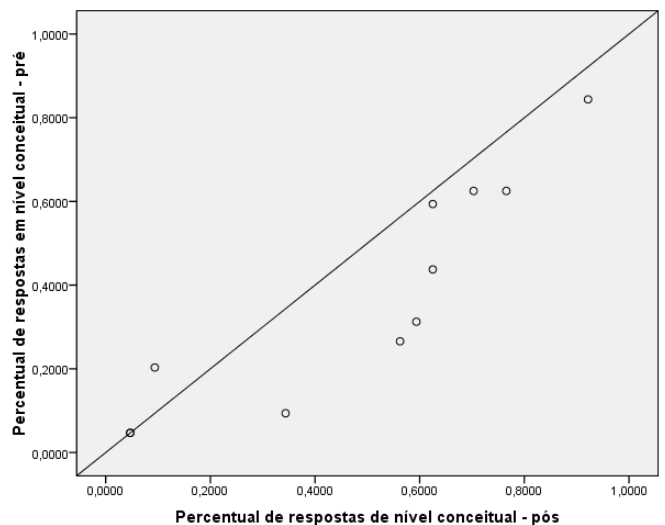

Gráfico 12 - Análise qualitativa da comparação das medianas dos Erros Perseverativos no WSCT antes e depois do procedimento de EMT

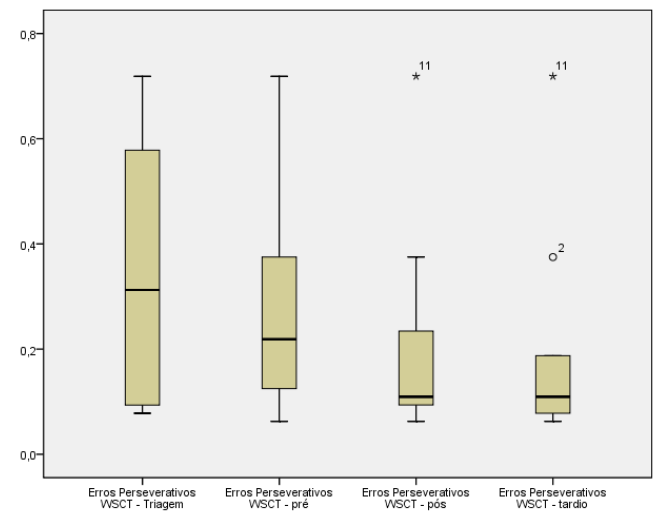

Gráfico 14 - Análise qualitativa da comparação das medianas dos Erros Não Perseverativos no WSCT antes e depois do procedimento de EMT

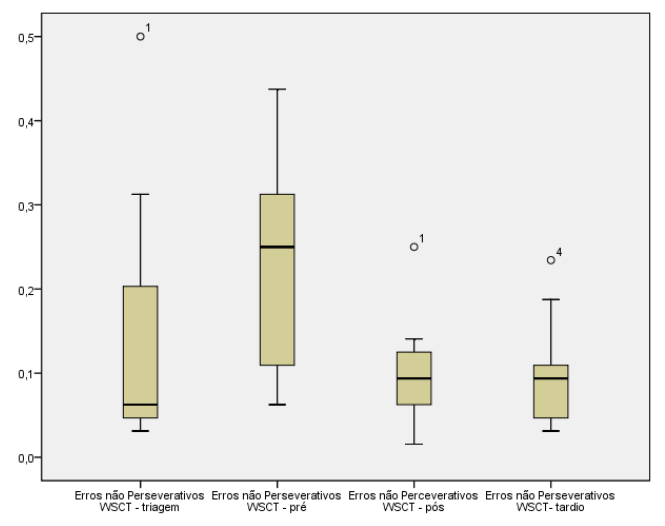

Gráfico 16 - Análise qualitativa da comparação das médias da formação de Nível Conceitual no WSCT antes e depois do procedimento de EMT

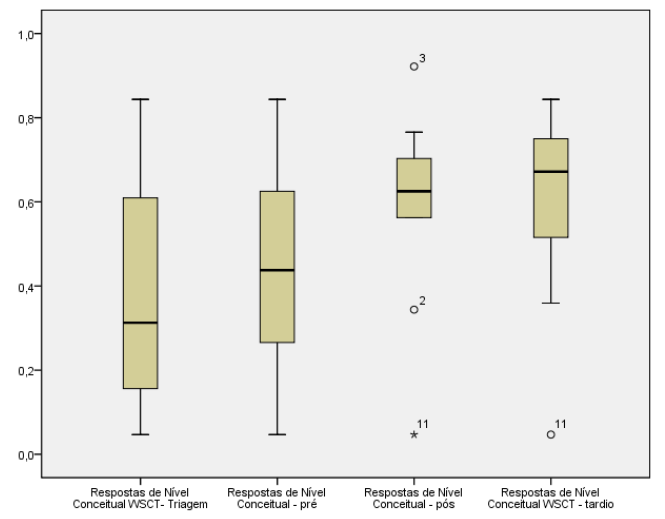


No STRROP test, os sujeitos mostraram mudanças significativas na soma dos tempos das três fases do teste $(p=0,001)$, (Gráfico 17 e 18). As mudanças relacionadas ao Número de Erros no STROOP não puderam ser notadas, pois todos os pacientes não apresentaram erros em nenhum dos dois tempos. Como ocorrido com as outras variáveis, a avaliação tardia também manteve um padrão semelhante à realizada logo após o procedimento de EMT.

Gráfico 17 - Análise qualitativa da comparação dos tempos totais para realizar o STROOP test antes e depois do procedimento de EMT

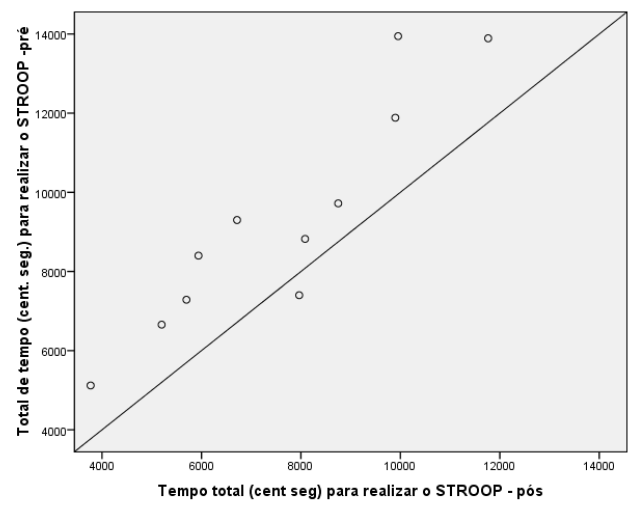

Gráfico 18 - Análise qualitativa da comparação das medianas dos Tempos Totais do STROOP test nos três tempos após triagem (Cent. Seg.)

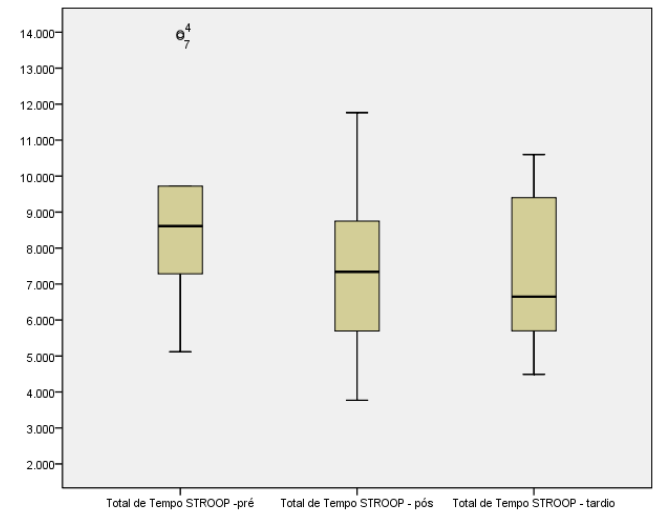

Foram encontradas diferenças nas mudanças entre os pacientes com o diagnóstico de Autismo (F84.0) e aqueles com Síndrome de Asperger (F84.5). Os sujeitos com Sd. de Asperger apresentaram mudanças mais significativas do que os pacientes com Autismo. As diferenças presentes com maior evidência foram o Total de Erros e a Formação de Nível Conceitual no WSCT. (Gráficos 19 e 20)

Gráfico 19 - Diferença entre Autistas e Síndrome de Asperger às mudanças ocorridas na Formação de Nível Conceitual no WSCT

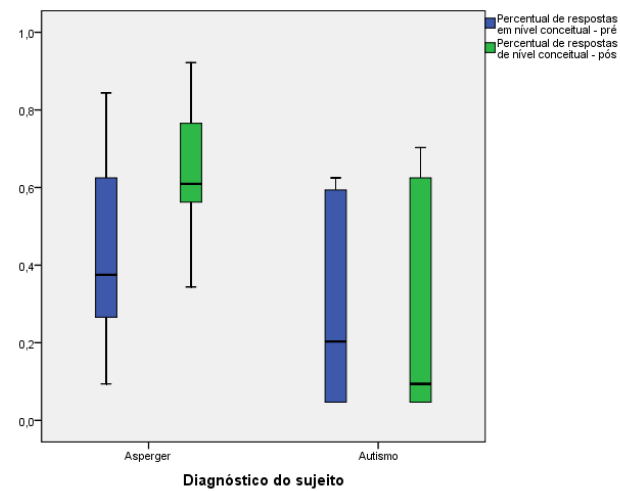

Gráfico 20 - Diferenças entre Autistas e Síndrome de Asperger às mudanças ocorridas no Total de Erros no WSCT

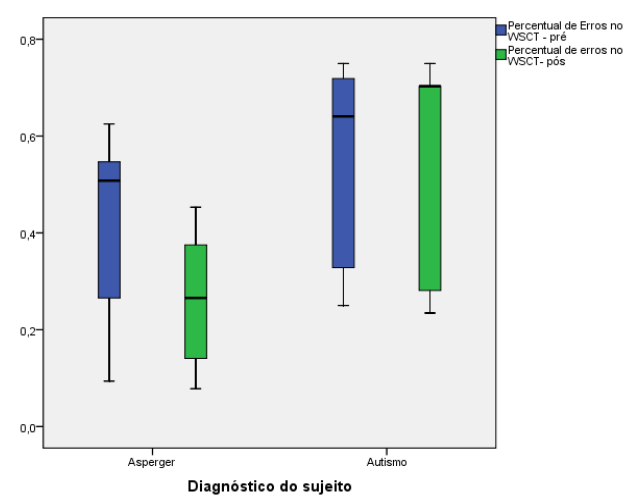


Como os indivíduos estão pareados pelo coeficiente de inteligência, a única diferença relevante entre os pacientes que pertencem aos dois grupos é a idade de início do desenvolvimento da linguagem. De fato, ao se analisar a correlação das curvas das mudanças ocorridas nas duas variáveis citadas acima e a curva que representa a Idade do Início do Desenvolvimento da Linguagem, pelo teste de Spearman, encontra-se uma curva de $(r=0,006)$ para o Total de Erros no WSCT e $(r=0,003)$ para a Formação de Nível Conceitual no WSCT. (Tabela 11)

Tabela 11 - Correlação entre as Variações: Total de Erros e a Formação de Nível Conceitual no WSCT e Idade de Início do desenvolvimento da Linguagem

\begin{tabular}{|c|c|c|c|c|c|}
\hline & & & $\begin{array}{l}\text { Idade em do } \\
\text { início das } \\
\text { primeiras } \\
\text { palavras }\end{array}$ & $\begin{array}{c}\text { Variação } \\
\text { entre total } \\
\text { de erros no } \\
\text { WSCT }\end{array}$ & $\begin{array}{l}\text { Variação entre } \\
\text { a formação de } \\
\text { nível } \\
\text { conceitual no } \\
\text { WSCT }\end{array}$ \\
\hline \multirow[t]{9}{*}{$\begin{array}{l}\text { Spearman's } \\
\text { rho }\end{array}$} & \multirow{3}{*}{$\begin{array}{l}\text { Idade em do } \\
\text { início das } \\
\text { primeiras } \\
\text { palavras }\end{array}$} & $\begin{array}{l}\text { Coeficiente de } \\
\text { Correlação }\end{array}$ & 1,000 &, $724^{* *}$ &,$- 758^{* *}$ \\
\hline & & $\begin{array}{l}\text { Coeficiente de } \\
\text { Correlação }\end{array}$ & . & ,006 & \\
\hline & & $\mathrm{N}$ & 11 & 11 & \\
\hline & \multirow{3}{*}{$\begin{array}{l}\text { Variação entre o } \\
\text { total de erros no } \\
\text { WSCT }\end{array}$} & $\begin{array}{l}\text { Coeficiente de } \\
\text { Correlação }\end{array}$ &, $724^{* *}$ & 1,000 &,$- 902^{* *}$ \\
\hline & & $\begin{array}{l}\text { Coeficiente de } \\
\text { Correlação }\end{array}$ & ,006 & & ,000 \\
\hline & & $\mathrm{N}$ & 11 & 11 & 11 \\
\hline & \multirow{3}{*}{$\begin{array}{l}\text { Variação entre a } \\
\text { formação de } \\
\text { nível conceitual } \\
\text { no WSCT }\end{array}$} & $\begin{array}{l}\text { Coeficiente de } \\
\text { Correlação }\end{array}$ &,$- 758^{* *}$ &,$- 902^{* *}$ & 1,000 \\
\hline & & $\begin{array}{l}\text { Coeficiente de } \\
\text { Correlação }\end{array}$ & ,003 & ,000 & \\
\hline & & $\mathrm{N}$ & 11 & 11 & 11 \\
\hline
\end{tabular}

Pode-se ainda inferir que a mudança ocorrida na inflexibilidade cognitiva está relacionada com a mudança no padrão de comportamento restrito e repetitivo, observado pelos pais e cuidadores. A curva que representa a mudança da inflexibilidade cognitiva representada pelo item Respostas Perseverativas do WSCT correlacionou-se com a mudança do Total de Pontos no RBS-r com $(r=0,049)$ e com a mudança no Total de Pontos para Compulsões no YBOCS com $(r=0,013)$ e 
também com a Variação dos Erros Perseverativos com $(r=0,016)$. (Tabela 12) A variação no Total de Erros no WSCT correlacionou-se com a Variação no Formação de Nível Conceitual com $(r=0,000)$. (Tabela 13)

Tabela 12 - Correlação entre a variação das variáveis: RBS total, YBOCS Compulsões Total, Respostas Perseverativas no WSCT e Erros Perseverativos no WSCT

\begin{tabular}{|c|c|c|c|c|c|c|}
\hline & & & $\begin{array}{c}\text { Variação } \\
\text { entre RBS } \\
\text { Total }\end{array}$ & $\begin{array}{c}\text { Variação } \\
\text { entre Y- } \\
\text { BOCS Total } \\
\text { Compulsão }\end{array}$ & $\begin{array}{c}\text { Variação entre } \\
\text { Respostas } \\
\text { Perseverativas } \\
\text { no WSCT }\end{array}$ & $\begin{array}{l}\text { Variação entre } \\
\text { os Erros } \\
\text { Perseverativos } \\
\text { no WSCT }\end{array}$ \\
\hline $\begin{array}{l}\text { Spearman's } \\
\text { rho }\end{array}$ & $\begin{array}{l}\text { Variação } \\
\text { entre RBS }\end{array}$ & $\begin{array}{l}\text { Correlation } \\
\text { Coefficient }\end{array}$ & 1,000 &, $585^{*}$ &, $523^{*}$ & ,329 \\
\hline & & Sig. (1-tailed) & & ,029 & ,049 &, 162 \\
\hline & & & 11 & 11 & 11 & 11 \\
\hline & Variação & &, $585^{*}$ & 1,000 & $664^{*}$ &, 018 \\
\hline & entre Y - & Sig. (1-tailed) & ,029 & . & ,013 & ,479 \\
\hline & compulsão & $\mathrm{N}$ & 11 & 11 & 11 & 11 \\
\hline & $\begin{array}{l}\text { Variação } \\
\text { entre }\end{array}$ & $\begin{array}{l}\text { Correlation } \\
\text { Coefficient }\end{array}$ &, $523^{*}$ & $664^{*}$ & 1,000 & ,646* \\
\hline & Respostas & Sig. (1-tailed) & ,049 & ,013 & & ,016 \\
\hline & no WSCT & $\mathrm{N}$ & 11 & 11 & 11 & 11 \\
\hline & $\begin{array}{l}\text { Variação } \\
\text { entre os }\end{array}$ & $\begin{array}{l}\text { Correlation } \\
\text { Coefficient }\end{array}$ & ,329 & ,018 &, $646^{*}$ & 1,000 \\
\hline & Erros & Sig. (1-tailed) & , 162 &, 479 &, 016 & \\
\hline & no WSCT & $\mathrm{N}$ & 11 & 11 & 11 & 11 \\
\hline
\end{tabular}

*. Correlation is significant at the 0.05 level (1-tailed).

WSCT - Wisconsin Sort Card Test.

Tabela 13 - Correlação entre a variação das variáveis: Total de Erros no WSCT e Formação de Nível Conceitual

\begin{tabular}{|c|c|c|c|c|}
\hline & & & $\begin{array}{c}\text { Variação entre } \\
\text { total de Erros no } \\
\text { WSCT }\end{array}$ & $\begin{array}{c}\text { Variação entre a } \\
\text { Formação de } \\
\text { Nível Conceitual } \\
\text { no WSCT } \\
\end{array}$ \\
\hline \multirow[t]{6}{*}{ Spearman's rho } & \multirow{3}{*}{$\begin{array}{l}\text { Variação entre } \\
\text { Total de Erros no } \\
\text { WSCT }\end{array}$} & $\begin{array}{l}\text { Correlation } \\
\text { Coefficient }\end{array}$ & 1,000 &,$- 902^{* *}$ \\
\hline & & Sig. (1-tailed) & . &, 000 \\
\hline & & $\mathrm{N}$ & 11 & 11 \\
\hline & \multirow{3}{*}{$\begin{array}{l}\text { Variação entre a } \\
\text { Formação de } \\
\text { Nível Conceitual } \\
\text { no WSCT }\end{array}$} & $\begin{array}{l}\text { Correlation } \\
\text { Coefficient } \\
\end{array}$ &,$- 902^{* *}$ & 1,000 \\
\hline & & Sig. (1-tailed) &, 000 & \\
\hline & & $\mathrm{N}$ & 11 & 11 \\
\hline
\end{tabular}

**. Correlation is significant at the 0.01 level (1-tailed).

WSCT - Wisconsin Sort Card Test. 
Ao correlacionar as mudanças ocorridas com as diferentes variáveis, antes e depois do procedimento de Estimulação Magnética Transcraniana, com o Coeficiente de Inteligência Total, de Execução e Verbal, encontram-se peculiaridades interessantes. O Coeficiente de Inteligência de Execução apresentou uma correlação diretamente proporcional com a Variação do Comportamento Compulsivo pelo RBS $(r=0,043)$ e uma correlação inversamente proporcional com o Comportamento de Auto Agressividade pelo RBS $(r=0,044)$. O Coeficiente de Inteligência Total e Verbal apresentaram correlação positiva com o item Comportamento Restrito do RBS $(r=0,041)$ e $(r=0,004)$ respectivamente. (Tabela 14)

Tabela 14 - Correlação entre o QI, QIe e QIv e as variações entre as variáveis: RBS Sub Escala 2, 3 e 6

\begin{tabular}{|c|c|c|c|c|c|c|c|c|}
\hline & & & $\begin{array}{c}\text { QI } \\
\text { pelo } \\
\text { WISC } \\
\text { III } \\
\end{array}$ & $\begin{array}{c}\text { QIe } \\
\text { pelo } \\
\text { WISC } \\
\text { III } \\
\end{array}$ & $\begin{array}{c}\text { QIv } \\
\text { pelo } \\
\text { WISC } \\
\text { III } \\
\end{array}$ & $\begin{array}{c}\text { Variação } \\
\text { entre } \\
\text { RBS sub } \\
\text { escala } 2 \\
\end{array}$ & $\begin{array}{c}\text { Variação } \\
\text { entre } \\
\text { RBS sub } \\
\text { escala } 3 \\
\end{array}$ & $\begin{array}{c}\text { Variação } \\
\text { entre } \\
\text { RBS sub } \\
\text { escala } 6 \\
\end{array}$ \\
\hline \multirow[t]{18}{*}{ Spearman's rho } & \multirow[t]{3}{*}{$\begin{array}{l}\text { QI pelo } \\
\text { WISC III }\end{array}$} & $\begin{array}{l}\text { Correlation } \\
\text { Coefficient } \\
\end{array}$ & 1,000 &, 462 & ,954** &,- 010 &, 273 &, $657^{*}$ \\
\hline & & Sig. (1-tailed) & . & ,089 &, 000 & ,489 & ,223 & ,019 \\
\hline & & $\mathrm{N}$ & 10 & 10 & 10 & 10 & 10 & 10 \\
\hline & \multirow[t]{3}{*}{$\begin{array}{l}\text { QIe pelo } \\
\text { WISC III }\end{array}$} & $\begin{array}{l}\text { Correlation } \\
\text { Coefficient }\end{array}$ & ,462 & 1,000 & ,430 &,- 391 & ,388 & ,037 \\
\hline & & Sig. (1-tailed) & 089 & & 107 &, 132 &, 134 & , 460 \\
\hline & & $\mathrm{N}$ & 10 & 10 & 10 & 10 & 10 & 10 \\
\hline & \multirow[t]{3}{*}{$\begin{array}{l}\text { QIv pelo } \\
\text { WISC III }\end{array}$} & $\begin{array}{l}\text { Correlation } \\
\text { Coefficient } \\
\end{array}$ &, $954^{* *}$ &, 430 & 1,000 &, 000 & ,494 &, $739^{* *}$ \\
\hline & & Sig. (1-tailed) &, 000 &, 107 & &, 500 & ,073 & ,007 \\
\hline & & $\mathrm{N}$ & 10 & 10 & 10 & 10 & 10 & 10 \\
\hline & \multirow{3}{*}{$\begin{array}{l}\text { Variação } \\
\text { entre RBS } \\
\text { sub escala } 2\end{array}$} & $\begin{array}{l}\text { Correlation } \\
\text { Coefficient } \\
\end{array}$ &,- 010 &,- 391 &, 000 & 1,000 &,- 226 & ,212 \\
\hline & & Sig. (1-tailed) & ,489 &, 132 &, 500 & & ,265 & ,278 \\
\hline & & $\mathrm{N}$ & 10 & 10 & 10 & 10 & 10 & 10 \\
\hline & \multirow{3}{*}{$\begin{array}{l}\text { Variação } \\
\text { entre RBS } \\
\text { sub escala } 3\end{array}$} & $\begin{array}{l}\text { Correlation } \\
\text { Coefficient } \\
\end{array}$ & ,273 & ,388 & ,494 &,- 226 & 1,000 & ,422 \\
\hline & & Sig. (1-tailed) & ,223 &, 134 & ,073 & ,265 & . & ,112 \\
\hline & & $\mathrm{N}$ & 10 & 10 & 10 & 10 & 10 & 10 \\
\hline & \multirow{3}{*}{$\begin{array}{l}\text { Variação } \\
\text { entre RBS } \\
\text { sub escala } 6\end{array}$} & $\begin{array}{l}\text { Correlation } \\
\text { Coefficient } \\
\end{array}$ &, $657^{*}$ & ,037 &, $739^{* * *}$ &, 212 & ,422 & 1,000 \\
\hline & & Sig. (1-tailed) & 019, & ,460 & ,007 & ,278 & ,112 & \\
\hline & & $\mathrm{N}$ & 10 & 10 & 10 & 10 & 10 & 10 \\
\hline
\end{tabular}

**. Correlation is significant at the 0.01 level (1-tailed).

*. Correlation is significant at the 0.05 level (1-tailed). 


\section{Discussão}


Primeiro estudo a tratar os sintomas de Comportamento Restrito e Repetitivo em pacientes com Transtorno do Espectro Autista que não possuem problemas cognitivos com Estimulação Magnética Transcraniana utilizando-se de um protocolo que recorre à estimulação com frequências de ondas Theta através do uso do paradigma "Theta Burst". O presente protocolo propõe um tratamento que envolve uma sequência de sessões com 5 dias consecutivos por semana, realizada durante três semanas. Até o presente momento, os estudos publicados haviam realizado protocolos inibitórios com frequência de sessões não superior a duas semanais. (Shokhadze E. et al., 2009, 2010, 2012)

Os trabalhos propostos até o presente momento pela literatura têm como objetivo utilizar a EMT com efeito inibitório agindo na fisopatologia da hiperexitação cortical, provocada pela dessincroniza entre o sistema excitatório e inibitório das células corticais. Este estudo procurou usar um protocolo excitatório com intuito de melhorar a conectividade e a formação de potenciais de longo prazo. (Jung H.N. et al. 2013)

Por se tratar de um estudo experimental, em que o número de participantes é reduzido, a análise dos dados referente à resposta dos sujeitos ao procedimento de EMT gera apenas suposições. O aprofundamento da análise será realizado com base em estudos futuros controlados, envolvendo número maior de participantes. Dessa forma, o uso do teste $\mathrm{T}$ pareado para analisar a significância das mudanças ocorridas nas variáveis antes e depois do procedimento de EMT e o uso do Teste de Spearman para avaliar as correlações entre as mudanças têm o objetivo restrito de dar uma ideia da magnitude da significância das respostas nesse grupo.

A seleção da região cerebral a ser estimulada seguiu critérios relacionados à fisiopatologia das funções executivas, responsáveis pela mudança do set e pela flexibilidade cognitiva que podem ter relação direta com os comportamentos restritos e repetitivos, à segurança e às limitações técnicas do aparelho utilizado para realização do procedimento de estimulação. (Aron A.R., Robbins T.W., Poldrack R.A., 2004) 
Evidências mostram que a faixa representada pelo CPFVL desde sua faixa inferior, representado pela área 47 de Brodmann, até a faixa médio superior, parte das áreas 46 e 9 de Brodmann, é responsável tanto pelo processo executivo da flexibilidade cognitiva, quanto pela função de mudança do set cognitivo, inclusive quando analisadas pelo Wisconsin Sort Card Test. (Monchi O. et al., 2001) Essas regiões, bilateralmente, podem estar comprometidas funcionalmente nos pacientes do Espectro Autista com comportamento restrito e repetitivo que possuem alterações nas funções executivas comentadas anteriormente. (Shafritz K.M. et al. 2008)

A região do CPFVL em sua porção médio superior, que representa as áreas 46 e 9 de Brodmann, é consagrada para a modulação do humor e dispõe-se como região a ser estimulada no tratamento da Depressão Maior, principalmente à esquerda. Dessa forma, ciente de que os pacientes com Transtorno do Espectro Autista podem apresentar uma maior sensibilidade às instabilidades emocionais, decidiu-se por não atuar diretamente nessas regiões em um primeiro momento. Assim, a região de escolha foi mais inferior o que corresponde à área 47 de Brodmann.

O uso do protocolo de frequência de ondas Theta objetiva melhorar a eficiência terapêutica. Existem evidências comprovando que os protocolos de Theta Burst têm maior facilidade de gerar potenciais de longa duração e, portanto, efeitos terapêuticos mais prolongados. (Nie T. et al., 2007) Como demonstrado, as mudanças apresentadas mantiveram-se após três meses do tratamento. Fortes evidências mostram que o efeito facilitador do protocolo de Theta Burst teria uma maior potência se existisse um estímulo fisiológico logo após cada sessão. (Huang Y. et al., 2008) Nos novos trabalhos, propostas terapêuticas comportamentais devem ser feitas após cada sessão para melhor eficiência dos resultados.

A escolha do protocolo de Theta Burst intermitente para o tratamento dos pacientes com Transtorno do Espectro Autista segue a hipótese da dificuldade inata na formação dos potenciais e da consolidação sináptica nos pacientes com Autismo de Alto Funcionamento. (Nicolson R. et al., 2006) Estudo com atividades motoras mostra que, apesar da hiperexcitação cortical, há problemas na conectividade sináptica excitatória para o hipocampo, gerando problemas funcionais e de aprendizado nesses pacientes. (Jung N.H. et al., 2012) 
Os efeitos de longa distância no hemisfério contralateral não foram ignorados, mesmo sabendo-se que a comunicação inter-hemisférica nos indivíduos com Transtorno do Espectro Autista pode estar comprometida. (Wolf J.J. et al., 2012) Para tanto, foi proposta a utilização do protocolo com intensidade de $100 \%$ do limiar motor, que promove efeitos facilitadores e depressores que se anulam no córtex contralateral. (Mochizuki H. et al., 2007) Esse fator, que nesse momento foi aproveitado como protetor, não causando efeitos no hemisfério esquerdo, pode ser explorado futuramente como uma abordagem terapêutica com efeitos em múltiplas regiões. Utilizar outras intensidades, $80 \%$ do limiar motor para um efeito inibitório ou $110 \%$ para promover efeito facilitador no hemisfério esquerdo, que podem ser aproveitadas, dependendo da proposta terapêutica.

Diferentemente das preocupações encontradas na literatura (Sokhadze E. et al., 2009), o tratamento com um protocolo que se utiliza da estimulação em indivíduos com Transtorno do Espectro Autista não gerou problemas quanto ao aumento da excitabilidade cortical, medido através dos sintomas como ansiedade, irritabilidade e o padrão de sono. Os pacientes se mantiveram estáveis em seus estados mentais durante todo o procedimento. Alguns responsáveis relataram aumento leve da atividade psicomotora nos primeiros três dias com posterior regulação. Outros sujeitos apresentaram o efeito oposto, diminuíram a atividade psicomotora nos primeiros dias, também com posterior regulação.

Um dos sujeitos apresentou dor facial durante a primeira sessão. Trata-se de um indivíduo de coeficiente de inteligência acima do normal, sem atraso no desenvolvimento da linguagem. Tudo indica que seu padrão de ansiedade estava aumentado nesse dia por estar sendo submetido a um procedimento novo. Após ser submetido a um procedimento de relaxamento, conseguiu fazer o procedimento sem problemas. Nas sessões seguintes, o procedimento de relaxamento foi utilizado e não houve mais referência quanto à dor facial.

Por se tratar de um teste neuropsicológico, o WSCT pode ser aprendido e o sujeito poderia apresentar mudanças nessas variáveis que não fossem causadas pelo procedimento de Estimulação Magnética Transcraniana. Pensando nessa hipótese, os pacientes foram apresentados à testagem com o WSCT três semanas antes de iniciar 
a fase 2, correspondente às testagens anteriores ao tratamento, e, assim, sanar a problemática do viés de aprendizagem.

Mudanças importantes foram encontradas em todas as variáveis relacionadas ao Wisconsin Sort Card Test. A medida de eficiência primária, Respostas Perseverativas, mostrou mudanças qualitativas importantes, mas as mudanças mais relevantes ocorreram nos Erros Perseverativos e na Formação de Nível Conceitual.

Nesse sentido, pode-se inferir que o tratamento com Estimulação Magnética Transcraniana, com o protocolo de estimulação por Theta Burst na porção antero inferior do CPFVL direito, tem uma eficiência para melhorar o padrão de inflexibilidade cognitiva nos pacientes com o Transtorno do Espectro Autista. A formação de conceitos novos também foi influenciada de forma positiva após o procedimento.

A distribuição dos dados relacionados à RBS foi muito mais homogênea do que a relacionada ao comportamento compulsivo pela YBOCS. Evidências mostram que os comportamentos compulsivos nos indivíduos com transtorno do Espectro Autista (TEA), quantitativamente, pouco diferem dos pacientes com Transtorno Obsessivo Compulsivo (TOC). As diferenças estariam na qualidade dos sintomas. Enquanto pacientes com TOC têm mais comportamentos de checar, limpar e contar; os pacientes com TEA têm comportamentos de tocar, tapear, esfregar e a autoagressão. (McDougle C.J. et al., 1995) Apesar de serem escalas que tratam de transtornos completamente diferentes em sua etiologia e psicopatologia, verificou-se uma forte correlação entre as mudanças ocorridas em cada uma delas após o procedimento de Estimulação Magnética.

O tratamento com EMT tem uma ação direta pontual e específica. Dessa forma, analisar a diferença no efeito terapêutico entre as três classes de comportamentos restritos e repetitivos propostas na literatura pode sugestionar mudanças mais específicas no padrão do comportamento. Sabe-se que a melhora do padrão cognitivo exclusivamente pode fazer com que os sintomas migrem dos comportamentos de ordem inferior para os comportamentos de ordem superior ou para insistência na mesmice, além de se poder encontrar mudanças mais intensas em determinada classe. (Lam K.S. et al., 2008)

Neste estudo, a análise das mudanças revelou mudanças semelhantes nas três formas de comportamentos. Os comportamentos de ordem inferior apresentaram 
mudança mais discreta. Vale notar, como era esperado, que existiu correlação entre as mudanças ocorridas nos comportamentos de ordem superior, na insistência na mesmice e no total de compulsões pelo Y-BOCS. Na literatura, apresentam-se ainda dúvidas se duas classes não seriam o suficiente para abordar a sintomatologia dessa forma de comportamentos, como proposto inicialmente. (Lewis M.H., Bodfish J.W., 1998; Tuner M., 1999)

Corroborando com a hipótese de que os sintomas relacionados ao comportamento restrito e repetitivo estão relacionados com a inflexibilidade cognitiva, houve uma correlação importante entre as curvas de mudanças ocorridas pelos testes aplicados aos pais e cuidadores RBS e YBOCS e as curvas de mudança ocorridas no WSCT, principalmente com as Respostas Perseverativas, medida de eficiência primária. Dessa maneira, existe uma forte evidência de que tornar os pacientes executivamente mais flexíveis pode refletir em uma mudança do comportamento para um padrão menos restrito e repetitivo.

Primariamente, duas variáveis relacionadas ao STROOP test foram analisadas, a somatória Total de Erros nas três etapas do teste e o tempo total para realizar todas as etapas. A variável relacionada ao Total de Erros foi descartada. Os pacientes tiveram um índice alto de acertos na fase 2 , anterior ao do tratamento. A variável que representa o Total de Tempo para realizar o teste apresentou uma mudança significante após o tratamento com EMT.

Somando as mudanças ocorridas pelas variáveis: Total de Erros, Erros não Perseverativos, Formação de Nível Conceitual no WSCT e Total de Tempo no STROOP, pode-se supor que este procedimento tem uma influência em outras funções cognitivas, pois os sujeitos apresentaram, de modo evidente, uma mudança no tempo cognitivo. A influência deste protocolo nas outras áreas representativas de funcionalidade deve, ainda, ser aprofundada em estudos futuros.

Os 11 pacientes que terminaram o protocolo, 5 sujeitos tinham o diagnóstico de Autismo e 6 tinham Síndrome de Asperger, mostraram diferenças nas mudanças ocorridas pelo Total de Erros e pela Formação de Nível Conceitual. Como os pacientes apresentavam-se pareados pela cognição, a diferença entre eles estava na idade do início do desenvolvimento da linguagem. A data do início das primeiras palavras, bem como as mudanças apresentadas pelas duas variáveis citadas 
mostraram, de fato, grande relevância estatística. Existem evidências que permitem relacionar os atrasos no desenvolvimento da linguagem com a lateralidade atípica dos quadros mais severos apresentados pelos pacientes com o Transtorno do Espectro Autista. O desequilíbrio eletrofisiológico apresentado por esse grupo de indivíduos culmina por atrasar o processo de dominância hemisférica, impactando no desenvolvimento da linguagem. (Lindell A.K., Hudry K., 2013) Pode-se sugerir a possibilidade de existir uma relação direta entre a eficiência terapêutica deste protocolo de EMT proposto e o impacto do transtorno na dominância hemisférica.

Apesar de existirem linhas de pesquisa que estudam as diferenças diagnósticas entre os pacientes com Autismo e com Síndrome de Asperger, os marcos de desenvolvimento dos pacientes e as características clínicas têm se mostrado mais importantes para definir as diferenças entre os pacientes com Transtorno do Espectro Autista. (Sharma S. et al., 2011) Há inúmeras evidências que denotam a importância do desenvolvimento da linguagem e das habilidade cognitivas para contrapor à intensidade dos comportamento restritos e repetitivos. (Leekam SR., Prior MR, Uljarevic M, 2011). Como demonstrado, realmente, ocorreram correlações entre as variações de algumas Sub Escalas do RBS e os coeficientes de inteligência verbal, executivo e geral.

Outras hipóteses sobre a não resposta de alguns pacientes ao tratamento devem ser levantadas. Podem existir determinados perfis de desenvolvimento dentro espectro autista que não respondem à formação de potenciais de longa duração após o Theta Burst. Recentemente, estudo em modelos animais com mutações nas proteínas PTEN, responsáveis pelo controle da proliferação celular e pela formação de sinapses, mostrou prejuízo na resposta à formação de pontencial de longo prazo induzido por Theta Burst em ratos de meia idade e adultos em sinapses entre $\mathrm{C} 1$ e $\mathrm{C} 3$ no hipocampo e nas células das vias perfurantes do giro denteado. (Takeuchi K. et al., 2013) Dessa forma, analisar o perfil neurobiológico dos pacientes que não responderam ao tratamento pode determinar protocolos específicos para cada subtipo de paciente.

Após o término do protocolo, foram realizadas entrevistas com responsáveis e profissionais das instituições de ensino em que os sujeitos estão inseridos. Foram pontuadas mudanças comportamentais que não foram analisadas por este estudo. 
Além de alguns relatos sobre melhora na fluência verbal, as principais mudanças que saltaram aos olhos de todos foram às relacionadas aos comportamentos sociais. Os pacientes começaram a se permitir uma exposição maior e se envolveram mais com os pares e com os adultos. A literatura permite compreender que a melhora nos comportamentos restritos e repetitivos podem impactar em mudanças na linguagem e sociabilidade. Novos estudos devem correlacionar as mudanças relacionadas a essas outras linhas de sintomas e analisá-las quantitativamente.

A melhora da fluência verbal, observada qualitativamente, deve-se ao efeito provável da estimulação sobre a região anexa, correspondente à área 45 de Brodmann. Conhecida por fazer parte da área de Broca, está ligada a funções expressivas da linguagem comunicativa. Estudo publicado recentemente mostrou melhora da linguagem expressiva após inibição da mesma área à esquerda. Pela influência inter-hemisférica, estimular a região contralateral pode ter efeito semelhante. (Fecteau S. et al., 2011)

Sabe-se que os efeitos da EMT produzem mudanças estruturais e funcionais nas regiões que diretamente foram expostas ao estímulo e em regiões comunicantes. (Lang N. et al., 2008; Ben-Shachar D. et al., 1999) Análises morfológicas e funcionais devem ser correlacionadas às mudanças ocorridas tanto no comportamento, quanto nos testes neuropsicológicos. Entender essas correlações permite conhecimento técnico para a formação de novos protocolos mais complexos que possam envolver múltiplas regiões a serem abordadas.

Existem evidências de mudanças nos circuitos neuroendócrinos e na transcrição genética em pacientes que foram submetidos à EMT. Medidas quantitativas que avaliam sistemas envolvidos com as bases do comportamento Autista podem ser realizadas em trabalhos futuros. Entender as bases neurobiológicas dessas alterações pode gerenciar medidas terapêuticas mais complexas com múltiplos focos para tratar outras regiões com o objetivo de ter melhora em outros sintomas. 


\section{Conclusão}


Após a submissão dos sujeitos selecionados pelo procedimento de Estimulação Magnética Transcraniana com o protocolo de estimulação por Theta Burst no Córtex Pré Frontal Ventro Lateral direito:

- Ocorreram mudanças positivas na função da flexibilidade cognitiva, representada pelas Respostas Perseverativas, Erros Perseverativos, e na Formação de Nível Conceitual do Wisconsin Sort Card Test. A velocidade de processamento cognitivo medido pelo Total de Tempo para realizar o STROOP test também apresentou mudança significativa.

- Os sujeitos apresentaram melhora do padrão de Comportamento Restrito e Repetitivo, medido pelas escalas RBS-r e YBOCS.

- Existe correlação entre as variações que representam a flexibilidade cognitiva e a melhora do Comportamento Restrito e Repetitivo.

- A possibilidade de se utilizar o Procedimento de EMT para tratar o Comportamento Restrito e Repetitivo com o diagnóstico de Autismo de alto funcionamento tem possibilidades que devem ser melhor analisadas com estudos controlados.

- Novas propostas de tratamento devem ser investigadas. Protocolos que incluam novas áreas de incidência e intensidades de estímulos que pudessem atingir outros objetivos clínicos devem ser tentadas. 


\section{Anexos}




\section{$\underline{\text { ANEXO } 1}$}

\section{CRITÉRIOS PARA DIAGNÓSTICO DO AUTISMO (CID-10) (WHO 1992)}

Pelo menos 8 dos 16 itens especificados devem ser satisfeitos.

\section{A. LESÃO MARCANTE NA INTERAÇÃO SOCIAL RECÍPROCA, MANIFESTADA POR PELO MENOS TRÊS DOS PRÓXIMOS CINCO ITENS:}

1. dificuldade em usar adequadamente o contato ocular, expressão facial, gestos e postura corporal para lidar com a interação social.

2. dificuldade no desenvolvimento de relações de companheirismo.

3. raramente procura conforto ou afeição em outras pessoas em tempos de tensão ou ansiedade, e/ou oferece conforto ou afeição a outras pessoas que apresentem ansiedade ou infelicidade.

4. ausência de compartilhamento de satisfação com relação a ter prazer com a felicidade de outras pessoas e/ou de procura espontânea em compartilhar suas próprias satisfações através de envolvimento com outras pessoas.

5. falta de reciprocidade social e emocional.

\section{B . MARCANTE LESÃO NA COMUNICAÇÃO:}

1. ausência de uso social de quaisquer habilidades de linguagem existentes.

2. diminuição de ações imaginativas e de imitação social.

3. pouca sincronia e ausência de reciprocidade em diálogos.

4. pouca flexibilidade na expressão de linguagem e relativa falta de criatividade e imaginação em processos mentais.

5. ausência de resposta emocional a ações verbais e não-verbais de outras pessoas.

6. pouca utilização das variações na cadência ou ênfase para refletir a modulação comunicativa.

7. ausência de gestos para enfatizar ou facilitar a compreensão na comunicação oral.

C. PADRÕES RESTRITOS, REPETITIVOS E ESTEREOTIPADOS DE COMPORTAMENTO, INTERESSES E ATIVIDADES, MANIFESTADOS POR PELO MENOS DOIS DOS PRÓXIMOS SEIS ITENS:

1. obsessão por padrões estereotipados e restritos de interesse.

2. apego específico a objetos incomuns.

3. fidelidade aparentemente compulsiva a rotinas ou rituais não funcionais específicos.

4. hábitos motores estereotipados e repetitivos.

5. obsessão por elementos não funcionais ou objetos parciais do material de recreação.

6. ansiedade com relação a mudanças em pequenos detalhes não funcionais do ambiente.

D. ANORMALIDADES DE DESENVOLVIMENTO DEVEM TER SIDO NOTADAS NOS PRIMEIROS TRÊS ANOS PARA QUE O DIAGNÓSTICO SEJA FEITO. 


\section{ANEXO 2}

\section{ESCALA OBSESSIVO-COMPULSIVO DE YALE-BROWN - Y-BOCS (Goodman et al., 1989)}

\section{As questões 1 a 5 são sobre PENSAMENTOS OBSESSIVOS.}

Obsessões são idéias, imagens ou impulsos indesejados que penetram no pensamento contra a vontade ou esforços para resistir a eles. Geralmente envolvem temas relacionados a danos, riscos ou perigos. Algumas obsessões comuns são: medo excessivo de contaminação, dúvidas recorrentes sobre perigo, preocupação extrema com ordem, simetria ou perfeição, medo de perder coisas importantes.

Por favor, responda cada questão assinalando o quadrado respectivo.

\begin{tabular}{|c|c|}
\hline $\begin{array}{l}\text { 1. TEMPO OCUPADO POR PENSAMENTOS } \\
\text { OBSESSIVOS } \\
\text { P.: Quanto de seu tempo é ocupado por } \\
\text { pensamentos obsessivos? } \\
\square 0=\text { Nenhum } \\
\square 1=\text { Menos de } 1 \text { hora/dia ou ocorrência ocasional } \\
\square 2=1 \text { a } 3 \text { horas/dia ou freqüente } \\
\square 3=\text { Mais de } 3 \text { horas até } 8 \text { horas/dia ou ocorrência } \\
\text { muito freqüente } \\
\square 4=\text { Mais de } 8 \text { horas/dia ou ocorrência quase } \\
\text { constante }\end{array}$ & $\begin{array}{l}\text { 4. RESISTÉNCIA CONTRA OBSESSÕES } \\
\text { P.: Até que ponto você se esforça para resistir aos } \\
\text { seus pensamentos obsessivos? Com que freqüência } \\
\text { você tenta não ligar ou distrair a atenção desses } \\
\text { pensamentos quando eles entram na sua mente? } \\
\square 0 \text { = Faz sempre esforço para resistir, ou sintomas } \\
\text { mínimos que não necessitam de resistência ativa. } \\
\square 1=\text { Tenta resistir a maior parte das vezes } \\
\square 2=\text { Faz algum esforço para resistir } \\
\square 3=\text { Entrega-se a todas as obsessões sem tentar } \\
\text { controlá-las, ainda que faça isso com alguma } \\
\text { relutância } \\
\square 4=\text { Cede completamente a todas as obsessões } \\
\text { de modo voluntário }\end{array}$ \\
\hline $\begin{array}{l}\text { 2. INTERFERÊNCIA provocada pelos } \\
\text { PENSAMENTOS OBSESSIVOS } \\
\text { P.: Até que ponto seus pensamentos obsessivos } \\
\text { interferem com seu trabalho, escola, vida social ou } \\
\text { outras atividades importantes? Há qualquer coisa } \\
\text { que você não faça por causa deles? } \\
\square 0=\text { Nenhuma } \\
\square 1=\text { Alguma: leve interferência com atividades } \\
\text { sociais ou ocupacionais, mas o desempenho geral } \\
\text { não é prejudicado } \\
\square 2=\text { Moderada: clara interferência no } \\
\text { desempenho social ou ocupacional, mas } \\
\text { conseguindo ainda desempenhar } \\
\square 3=\text { Grave: provoca prejuízo considerável no } \\
\text { desempenho social ou ocupacional } \\
\square 4=\text { Muito grave: incapacitante }\end{array}$ & $\begin{array}{l}\text { 5. GRAU DE CONTROLE SOBRE OS } \\
\text { PENSAMENTOS OBSESSIVOS } \\
\text { P.: Até que ponto você consegue controlar os seus } \\
\text { pensamentos obsessivos? É habitualmente bem-sucedido } \\
\text { quando tenta afastar a atenção dos pensamentos } \\
\text { obsessivos ou interrompê-los? Consegue afastá-los? } \\
\square 0=\text { Controle total } \\
\square 1 \text { = Bom controle: geralmente capaz de } \\
\text { interromper ou afastar as obsessões com } \\
\text { algum esforço e concentração } \\
\square 2 \text { = Controle moderado: algumas vezes capaz de } \\
\text { interromper ou afastar as obsessões } \\
\square 3 \text { = Controle leve: raramente bem sucedido } \\
\text { quando tenta interromper ou afastar as } \\
\text { obsessões, consegue somente desviar a } \\
\text { atenção com dificuldade. } \\
\square \quad=\text { Nenhum controle: as obsessões } \\
4 \text { experimentadas como completamente } \\
\text { involuntárias, raramente capaz, mesmo que } \\
\text { seja momentaneamente, de desviar seus } \\
\text { pensamentos obsessivos. }\end{array}$ \\
\hline $\begin{array}{l}\text { 3. SOFRIMENTO relacionado aos PENSAMENTOS } \\
\text { OBSESSIVOS } \\
\text { P.: Até que ponto os seus pensamentos obsessivos } \\
\text { o perturbam ou provocam mal-estar em você? (Na } \\
\text { maior parte dos casos, a perturbação/mal-estar é } \\
\text { equivalente à ansiedade; contudo, alguns pacientes } \\
\text { podem descrever as suas obsessões como } \\
\text { perturbadoras mas negam sentir ansiedade. (Avalie } \\
\text { somente a ansiedade que parece ser desencadeada } \\
\text { pelas obsessões, não a ansiedade generalizada ou } \\
\text { a ansiedade associada a outras condições). } \\
\square 0=\text { Nenhuma } \\
\square 1=\text { Não atrapalha muito } \\
\square 2=\text { Incomoda, mas ainda é controlável } \\
\square 3=\text { Muito incômoda } \\
\square 4=\text { Angústia constante e incapacitante }\end{array}$ & 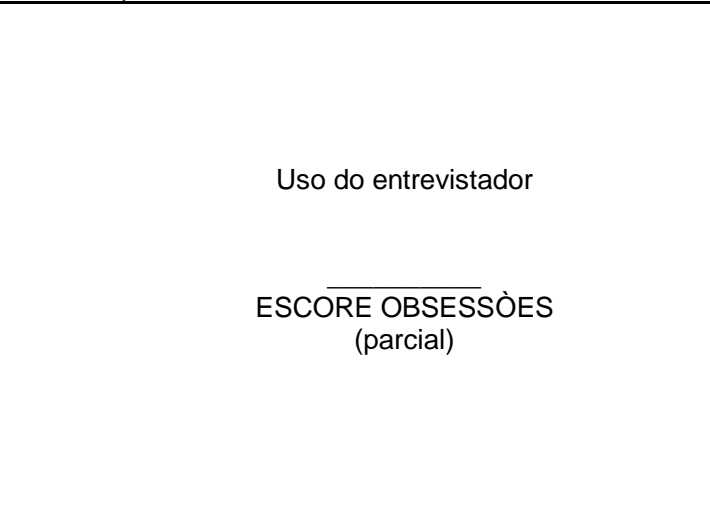 \\
\hline
\end{tabular}


As questões seguintes são sobre COMPORTAMENTOS COMPULSIVOS.

As compulsões são impulsos que as pessoas têm que fazer para diminuir sentimentos de ansiedade ou outro desconforto. Freqüentemente, elas têm comportamentos intencionais repetitivos, propostos, chamados rituais. $O$ comportamento em si pode parecer apropriado, mas se torna um ritual quando feito em excesso. Lavar, conferir, repetir, organizar, acumular coisas e outros comportamentos podem ser rituais. Alguns rituais são mentais. Por exemplo, pensar ou dizer coisas várias vezes em voz baixa.

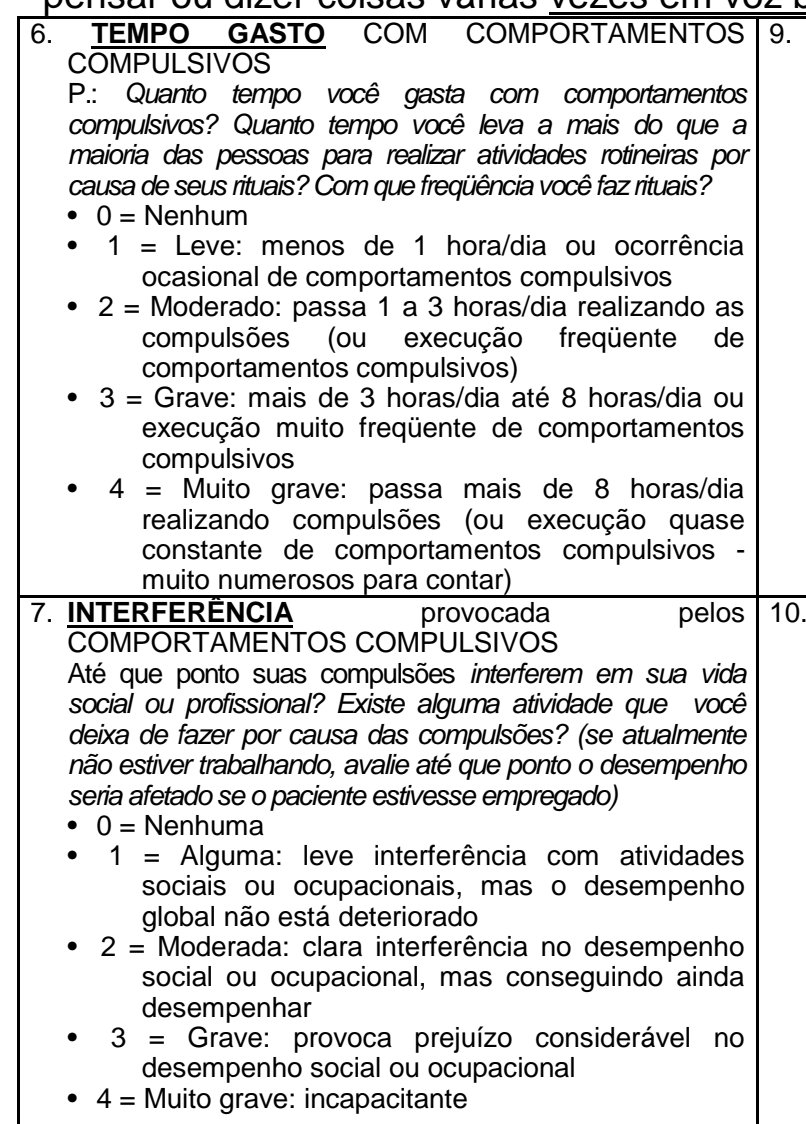

\section{RESISTÉNCIA às COMPULSÖES}

P.: Até que ponto você se esforça para resistir às suas

compulsões?
$\square 0=$ Faz sempre esforço para resistir ou sintomas tão mínimos que não necessitam de resistência ativa

$\square 1=$ Tenta resistir na maior parte das vezes

$\square 2$ = Faz algum esforço para resistir

$\square 3$ = Cede a todas as compulsões sem tentar controlá-las, ainda que faça isso com alguma relutância

$\square 4$ = Cede completamente a todas as compulsões de modo voluntário

GRAU DE CONTROLE SOBRE O

COMPORTAMENTO COMPULSIVO

$\mathrm{P}$. .: Com que força você se sente obrigado a executar os comportamentos compulsivos? Até que ponto consegue controlar as suas compulsões?

$\square 0$ = Controle total

$\square 1$ = Bom controle: sente-se pressionado a realizar as compulsões mas tem algum controle voluntário

$\square 2$ = Controle moderado: sente-se fortemente pressionado a realizar as compulsões e somente consegue controlá-las com dificuldade

$\square 3$ = Controle leve: pressão muito forte para executar as compulsões; o comportamento compulsivo tem que ser executado até o fim e somente com dificuldade consegue retardar a execução dessas compulsões

$\square 4$ = Nenhum controle: a pressão para realizar as compulsões é experimentada como completamente dominadora e involuntária; raramente capaz de, mesmo que seja momentaneamente, de retardar a execução das compulsões

8. SOFRIMENTO relacionado aos COMPORTAMENTOS COMPULSIVOS

P.: Como você sentiria se fosse impedido de realizar sua(s) compulsão(ões)? Quão ansioso você ficaria?

$\square 0$ = Nenhum

$\square 1$ = Leve: ligeiramente ansioso se as compulsões forem interrompidas, ou ligeiramente ansioso durante a sua execução

$\square 2$ = Moderado: A ansiedade sobe a um nível controlável se as compulsões forem interrompidas, ou a ansiedade sobe a um nível controlável durante a sua execução

$\square 3$ = Intenso: aumento proeminente e muito perturbador da ansiedade se as compulsões forem interrompidas, ou aumento de ansiedade proeminente e muito perturbador durante sua execução

$\square 4$ = Muito intenso: ansiedade incapacitante a partir de qualquer intervenção com o objetivo de modificar as compulsões, ou ansiedade incapacitante Durante a execução das compulsões

Uso do entrevistador

ESCORE COMPULSÕES 


\section{$\underline{\text { ANEXO } 3}$}

\section{REPETITIVE BEHAVIOR SCALE - Revised (RBS-R)}

Name:

Gender: female male
Date of Birth:

ID\#:

Informant's Name:
Today's Date:

\section{Instructions}

Please rate this person's behavior by reading each of the items listed and then choosing the score that best describes how much of a problem the item is for the person. Be sure to read and score all items listed. Make your ratings based on your observations and interactions with the person over the last month. Use the definitions in the box given below to score each item.

$$
\begin{aligned}
& 0=\text { behavior does not occur } \\
& 1=\text { behavior occurs and is a mild problem } \\
& 2=\text { behavior occurs and is a moderate problem } \\
& 3=\text { behavior occurs and is a severe problem }
\end{aligned}
$$

When deciding on a score for each item, consider: (a) how frequently the behavior occurs (e.g. weekly versus hourly), (b) how difficult it is to interrupt the behavior (e.g. can be easily redirected versus becomes distressed if interrupted) and (c) how much the behavior interferes with ongoing

\begin{tabular}{|c|c|c|c|c|c|}
\hline 1 & WHOLE BODY (Body rocking, Body swaying) & 0 & 1 & 2 & 3 \\
\hline 2 & HEAD (Rolls head, Nods head, Turns head) & 0 & 1 & 2 & 3 \\
\hline 3 & $\begin{array}{l}\text { HAND/FINGER (Flaps hands, Wiggles or flicks fingers, Claps hands, Waves or shakes hand or } \\
\text { arm) }\end{array}$ & 0 & 1 & 2 & 3 \\
\hline 4 & LOCOMOTION (Turns in circles, Whirls, Jumps, Bounces) & 0 & 1 & 2 & 3 \\
\hline 5 & $\begin{array}{l}\text { OBJECT USAGE (Spins or twirls objects, Twiddles or slaps or throws objects, Lets objects fall } \\
\text { out of hands) }\end{array}$ & 0 & 1 & 2 & 3 \\
\hline 6 & $\begin{array}{l}\text { SENSORY (Covers eyes, Looks closely or gazes at hands or objects, Covers ears, Smells or } \\
\text { sniffs items, Rubs surfaces) }\end{array}$ & 0 & 1 & 2 & 3 \\
\hline
\end{tabular}
events (e.g. easy to ignore versus very disruptive).

\section{Stereotyped Behavior Subscale}

(DEFINITION: apparently purposeless movements or actions that are repeated in a similar manner) 


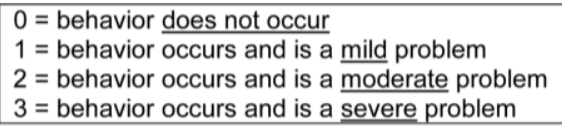

\section{Self-Injurious Behavior Subscale}

(DEFINITION: movement or actions that have the potential to cause redness, bruising, or other injury to the body, and that are repeated in a similar manner)

\begin{tabular}{|c|c|c|c|c|c|}
\hline 7 & HITS SELF WITH BODY PART (Hits or slaps head, face, or other body area) & 0 & 1 & 2 & 3 \\
\hline 8 & $\begin{array}{l}\text { HITS SELF AGAINST SURFACE OR OBJECT (Hits or bangs head or other body part on table, } \\
\text { floor or other surface) }\end{array}$ & 0 & 1 & 2 & 3 \\
\hline 9 & HITS SELF WITH OBJECT (Hits or bangs head or other body area with objects) & 0 & 1 & 2 & 3 \\
\hline 10 & BITES SELF (Bites hand, wrist, arm, lips or tongue) & 0 & 1 & 2 & 3 \\
\hline 11 & PULLS (Pulls hair or skin) & 0 & 1 & 2 & 3 \\
\hline 12 & RUBS OR SCRATCHES SELF (Rubs or scratches marks on arms, leg, face or torso) & 0 & 1 & 2 & 3 \\
\hline 13 & INSERTS FINGER OR OBJECT (Eye-poking, Ear-poking) & 0 & 1 & 2 & 3 \\
\hline 14 & SKIN PICKING (Picks at skin on face, hands, arms, legs or torso) & 0 & 1 & 2 & 3 \\
\hline
\end{tabular}

\section{Compulsive Behavior Subscale}

(DEFINITION: behavior that is repeated and is performed according to a rule, or involves things being done "just so")

\begin{tabular}{|c|c|c|c|c|c|}
\hline 15 & $\begin{array}{l}\text { ARRANGING / ORDERING (Arranges certain objects in a particular pattern or place; Need for } \\
\text { things to be even or symmetrical) }\end{array}$ & 0 & 1 & 2 & 3 \\
\hline 16 & $\begin{array}{l}\text { COMPLETENESS (Must have doors opened or closed; Takes all items out of a container or } \\
\text { area) }\end{array}$ & 0 & 1 & 2 & 3 \\
\hline 17 & WASHING / CLEANING (Excessively cleans certain body parts; Picks at lint or loose threads) & 0 & 1 & 2 & 3 \\
\hline 18 & CHECKING (Repeatedly checks doors, windows, drawers, appliances, clocks, locks, etc.) & 0 & 1 & 2 & 3 \\
\hline 19 & COUNTING (Counts items or objects; Counts to a certain number or in a certain way) & 0 & 1 & 2 & 3 \\
\hline 20 & HOARDING/SAVING (Collects, hoards or hides specific items) & 0 & 1 & 2 & 3 \\
\hline 21 & REPEATING (Need to repeat routine events; In / out door, up / down from chair, clothing on/off) & 0 & 1 & 2 & 3 \\
\hline 22 & TOUCH / TAP (Need to touch, tap, or rub items, surfaces, or people) & 0 & 1 & 2 & 3 \\
\hline
\end{tabular}




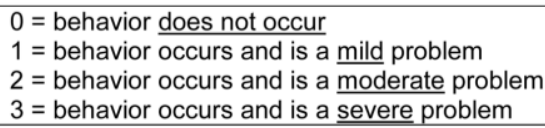

\section{Ritualistic Behavior Subscale}

(DEFINITION: performing activities of daily living in a similar manner)

\begin{tabular}{|c|c|c|c|c|c|}
\hline 23 & $\begin{array}{l}\text { EATING / MEALTIME (Strongly prefers/insists on eating/drinking only certain things; Eats or } \\
\text { drinks items in a set order; Insists that meal related items are arranged in a certain way) }\end{array}$ & 0 & 1 & 2 & 3 \\
\hline 24 & $\begin{array}{l}\text { SLEEPING / BEDTIME (Insists on certain pre-bedtime routines; Arranges items in room "just } \\
\text { so" prior to bedtime; Insists that certain items be present with him/her during sleep; Insists that } \\
\text { another person be present prior to or during sleep) }\end{array}$ & 0 & 1 & 2 & 3 \\
\hline 25 & $\begin{array}{l}\text { SELF-CARE - BATHROOM AND DRESSING (Insists on specific order of activities or tasks } \\
\text { related to using the bathroom, to washing, showering, bathing or dressing; Arranges items in a } \\
\text { certain way in the bathroom or insists that bathroom items not be moved; Insists on wearing } \\
\text { certain clothing items) }\end{array}$ & 0 & 1 & 2 & 3 \\
\hline 26 & $\begin{array}{l}\text { TRAVEL / TRANSPORTATION (Insists on taking certain routes/paths; Must sit in specific } \\
\text { location in vehicles; Insists that certain items be present during travel, e.g., toy or material; } \\
\text { Insists on seeing or touching certain things or places during travel such as a sign or store) }\end{array}$ & 0 & 1 & 2 & 3 \\
\hline 27 & $\begin{array}{l}\text { PLAY / LEISURE (Insists on certain play activities; Follows a rigid routine during play / leisure; } \\
\text { Insists that certain items be present/available during play/leisure; Insists that other persons do } \\
\text { certain things during play) }\end{array}$ & 0 & 1 & 2 & 3 \\
\hline 28 & $\begin{array}{l}\text { COMMUNICATION / SOCIAL INTERACTIONS (Repeats same topic(s) during social } \\
\text { interactions; Repetitive questioning; Insists on certain topics of conversation; Insists that others } \\
\text { say certain things or respond in certain ways during interactions) }\end{array}$ & 0 & 1 & 2 & 3 \\
\hline
\end{tabular}

\section{Sameness Behavior Subscale}

(DEFINITION: (resistance to change, insisting that things stay the same)

\begin{tabular}{|c|c|c|c|c|c|}
\hline 29 & Insists that things remain in the same place(s) (e.g. toys, supplies, furniture, pictures, etc.) & 0 & 1 & 2 & 3 \\
\hline 30 & Objects to visiting new places & 0 & 1 & 2 & 3 \\
\hline 31 & Becomes upset if interrupted in what he/she is doing & 0 & 1 & 2 & 3 \\
\hline 32 & Insists on walking in a particular pattern (e.g., straight line) & 0 & 1 & 2 & 3 \\
\hline 33 & Insists on sitting at the same place & 0 & 1 & 2 & 3 \\
\hline 34 & Dislikes changes in appearance or behavior of the people around him/her & 0 & 1 & 2 & 3 \\
\hline 35 & Insists on using a particular door & 0 & 1 & 2 & 3 \\
\hline 36 & $\begin{array}{l}\text { Likes the same CD, tape, record or piece of music played continually; Likes same movie / video } \\
\text { or part of movie / video }\end{array}$ & 0 & 1 & 2 & 3 \\
\hline 37 & Resists changing activities; Difficulty with transitions & 0 & 1 & 2 & 3 \\
\hline 38 & Insists on same routine, household, school or work schedule everyday & 0 & 1 & 2 & 3 \\
\hline 39 & Insists that specific things take place at specific times & 0 & 1 & 2 & 3 \\
\hline
\end{tabular}




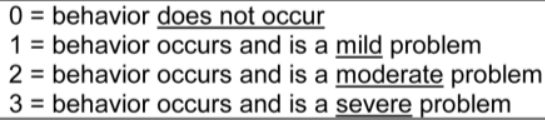

\section{Restricted Behavior Subscale}

(DEFINITION: Limited range of focus, interest or activity)

\begin{tabular}{|c|c|c|c|c|c|}
\hline 40 & $\begin{array}{l}\text { Fascination, preoccupation with one subject or activity (e.g., trains, computers, weather, } \\
\text { dinosaurs) }\end{array}$ & 0 & 1 & 2 & 3 \\
\hline 41 & Strongly attached to one specific object & 0 & 1 & 2 & 3 \\
\hline 42 & $\begin{array}{l}\text { Preoccupation with part(s) of object rather than the whole object (e.g., buttons on clothes, } \\
\text { wheels on toy cars) }\end{array}$ & 0 & 1 & 2 & 3 \\
\hline 43 & Fascination, preoccupation with movement / things that move (e.g., fans, clocks) & 0 & 1 & 2 & 3 \\
\hline
\end{tabular}

\section{Scoring Summary:}

1. Number of subscale items endorsed: number of items in a subscale rated 1,2 , or 3

2. Total subscale score: sum of the ratings for all of the items in a subscale

3. Overall number of items endorsed: sum of the "Number of subscale items endorsed"

4. Overall score: sum of the "Total subscale scores"

\begin{tabular}{|l|l|l|}
\hline Subscale & Number of subscale items endorsed & Total subscale score \\
\hline I. Stereotyped Behavior & & \\
\hline II. Self-injurious Behavior & & \\
\hline III. Compulsive Behavior & & \\
\hline IV. Ritualistic Behavior & & \\
\hline V. Sameness Behavior & & \\
\hline VI. Restricted Behavior & & \\
\hline
\end{tabular}

\begin{tabular}{|c|c|}
\hline $\begin{array}{c}\text { Overall number of items } \\
\text { endorsed }\end{array}$ & Overall Score \\
\hline & \\
\hline
\end{tabular}

References for RBS-R

Bodfish, J.W., Symons, F.J., Parker, D.E., \& Lewis, M.H. (2000). Varieties of repetitive behavior in autism. Journal of Autism and Developmental Disabilities, 30, 237-243.

Bodfish, J.W., Symons, F.J., Lewis, M.H. (1999). The Repetitive Behavior Scale. Western Carolina Center Research Reports. 


\section{ANEXO 4 \\ HOSPITAL DAS CLÍNICAS DA FACULDADE DE MEDICINA DA UNIVERSIDADE DE SÃO PAULO-HCFMUSP TERMO DE CONSENTIMENTO LIVRE E ESCLARECIDO}

\section{DAdOS DE IDENTIFICAÇÃO DO SUJEITO DA PESQUISA OU RESPONSÁVEL LEGAL}

1.NOME:

DOCUMENTO DE IDENTIDADE: SEXO : .M $\square$ F $\square$

DATA NASCIMENTO:

ENDERECO: No COMPLEMENTO: BAIRRO: CIDADE: CEP: TELEFONES:

2.RESPONSAVEL LEGAL:

NATUREZA (grau de parentesco, tutor, curador etc.): DOCUMENTO DE IDENTIDADE: SEXO: M $\square$ F $\square$

DATA NASCIMENTO: 1 ENDERECO: No COMPLE MENTO BAIRRO: CIDADE CEP: TELEFONES:

\section{DADOS SOBRE A PESQUISA}

1. TITULO DO PROTOCOLO DE PESQUISA:

PESQUISADOR:

CARGO/FUNCAO:

INSCRICAO CONSELHO REGIONAL No UNIDADE DO HCFMUSP:

3. AVALIACAO DO RISCO DA PESQUISA:

RISCO MINIMO $\square \quad$ RISCO MEDIO $\square \quad$ RISCO BAIXO $\square$ RISCO MAIOR $\square$ 


\section{HOSPITAL DAS CLÍNICAS DA FACULDADE DE MEDICINA DA UNIVERSIDADE DE SÃO PAULO-HCFMUSP}

Este estudo tem por base avaliar a resposta clínica e neuropsicológica do tratamento realizado com Estimulação Magnética Transcraniana (EMT) em crianças e adolescentes com o Transtorno do Espectro Autista. O tratamento em questão tem por objetivo testar uma alternativa não medicamentosa para alivio dos sintomas relacionados comportamento restrito e repetitivo e a inflexibilidade cognitiva. A presença dos pacientes em questão tem caráter voluntário.

Após a assinatura do desse termo o paciente será incluído na fase 1 da pesquisa. Através de observação clínica e entrevistas com os responsáveis, serão aplicados questionários estruturados e validados para avaliação do quadro clínico. Ao todo serão três momentos, cada um com uma duração máxima de duas horas: Avaliação Clínica, WISC-III e KSADS. Ainda teremos um momento em que a criança realizará exames complementares: um Eletroencefalograma e Ressonância Magnética Trascraniana. O único incômodo é um ruído constante de volume moderado.

A fase 2 corresponde a um momento, prévio a intervenção, em que os responsáveis e a criança responderão dois questionários relacionados ao comportamento atual da criança. Juntos tem duração de uma hora. Após, a criança fará um teste de função executiva concomitante com o eletroencefalograma. O mesmo tem a duração de no máximo dez minutos. A preparação da cabeça da criança para o exame deve se prolongar por meia hora. Serão alocados eletrodos à cabeça que ficam aderidos a mesma por uma pasta. O paciente não sofrerá dor ou qualquer sintoma de incômodo, além de não correr risco de reações ou alergias.

Para o procedimento de EMT, fase 3, será realizada uma sessão diária de estimulação, por quinze dias, em três semanas consecutivas, havendo pausas nos finais de semana. As sessões terão a duração de 15 minutos e serão realizadas no ambulatório de EMT do IPq-FMUSP, em data e horário pré estipulados. A preparação dos indivíduos para o procedimento pode levar até 30 minutos. A criança ficará sentada em uma cadeira reclinável aonde irá vestir uma toca de natação. Após a medição da cabeça com fita métrica a toca será marcada com caneta pincel. A bobina, então será aproximada do ponto de marcação e o procedimento se iniciará. Não há caráter invasivo e o indivíduo não receberá qualquer tipo de medicação ou sedação durante o procedimento. Só será ouvido um barulho que se assemelha a um bipe de baixo volume e contínuo. Os únicos desconfortos, que ocorrem raramente, podem ser: contração fraca da musculatura facial e leve cefaleia. A EMT será automaticamente cessada caso existam situações que gerem intolerância do paciente.

Em caso de necessidade será proporcionado transporte aos pacientes e responsáveis. Será fornecido lanche às crianças que estarão acompanhadas de um médico caso ocorra alguma intercorrência.

Haverá um último momento, fase 4, em que o mesmo procedimento realizado na fase 2 será repetido. Será logo após o término da última sessão de Estimulação Magnética Transcraniana.

Não há certificação de benefício direto para o indivíduo que participará do estudo. Trata-se de um estudo em que se realiza um protocolo experimental testando a hipótese de que as alterações elétricas e funcionais realizadas pelo procedimento de Estimulação Magnética Transcraniana irão promover melhora dos sintomas típicos do Transtorno do Espectro Autista, principalmente os relacionados ao comportamento restrito e repetitivos. Somente no final do estudo poderemos concluir se ocorreu algum benefício.

Garantia de acesso: em qualquer etapa do estudo, os familiares ou responsáveis terão acesso aos profissionais responsáveis pela pesquisa para esclarecimento de eventuais dúvidas. O principal investigador é o Dr. Marco Antônio Marcolin, que pode ser encontrado no endereço: Rua Dr. Ovidio Pires de Campos 785 - segundo andar, ala sul, Bairro Cerqueira Cesar Telefone: (11) 3069-8159 - email: emt @ hcnet.usp.br. Se existir alguma consideração ou dúvida 
quanto às questões éticas da pesquisa, entre em contato com o Comitê de Ética em Pesquisa (CEP) - Rua Ovidio Pires de Campos, 225 - $5^{\circ}$ andar - tel: (11) 3069-6442 ramais 16, 17, 18 ou 20, FAX: 3069-6442 ramal 26 - E-mail: cappesq@ @onet.usp.br.

É garantida a liberdade de saída do estudo, sem qualquer prejuízo na continuidade de seu tratamento na Instituição.

Direito de confidencialidade: não será divulgada a identificação de nenhum paciente.

Os responsáveis terão o direito de serem atualizados sobre os resultados parciais da pesquisa ou de resultados que sejam do conhecimento dos pesquisadores.

Despesas e compensações: não haverá despesas pessoais para o participante em qualquer fase do estudo, incluindo exames e consultas; também não há compensação financeira relacionada à sua participação. Se existir qualquer despesa adicional, ela será absorvida pelo orçamento da pesquisa.

Há compromisso do pesquisador de utilizar os dados e o material coletado somente para esta pesquisa.

Dos responsáveis:

Acredito ter sido suficientemente informado a respeito das informações que li ou que foram lidas para mim, descrevendo o estudo "Estimulação Magnética em crianças com Autismo".

Eu discuti com o Dr. Marco Antônio Marcolin e sua equipe sobre a minha decisão em participar nesse estudo. Ficaram claros para mim quais são os propósitos do estudo, os procedimentos a serem realizados, seus desconfortos e riscos, as garantias de confidencialidade e de esclarecimentos permanentes. Ficou claro também, que minha participação é isenta de despesas e que tenho garantia do acesso a tratamento hospitalar quando necessário. Concordo voluntariamente em participar deste estudo e poderei retirar o meu consentimento a qualquer momento, antes ou durante o mesmo, sem penalidades ou prejuízo ou perda de qualquer benefício que eu tenha adquirido com relação meu atendimento neste Serviço.

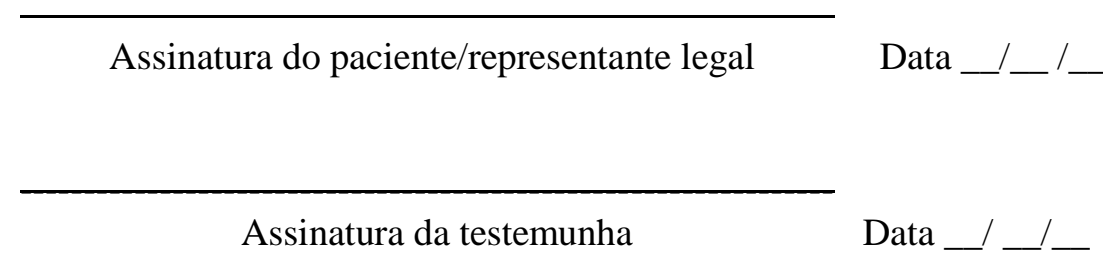

Declaro que obtive de forma apropriada e voluntaria o Consentimento Livre e Esclarecido deste paciente ou representante legal para a participação neste estudo.

Assinatura do responsável pelo estudo

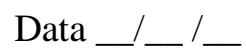


10 Referências 
Aleman A, Sommer I, Kahn R. Efficacy of slow repetitive transcranial magnetic stimulation in the treatment of resistant auditory hallucinations in schizophrenia: a meta-analysis. Journal of Clinical Psychiatry 2007; 68:416-421

Allan C, Hermann L, Ebmeier K. Transcranial magnetic stimulation in the management of mood disorders. Neuropsychopharmacology 2011; 64: 163-169.

American Psychiatric Association (APA). Diagnostic and Statistical Manual of Mental Disorders III. Washington. American Psychiatric Association, 1980.

American Psychiatric Association (APA). Diagnostic and Statistical Manual of Mental Disorders III-R. Washington. American Psychiatric Association, 1987.

American Psychiatric Association (APA). Diagnostic and Statistical Manual of Mental Disorders IV. Washington. American Psychiatric Association, 1994.

Angelidou A, Asadi S, Alysandratos K.D, Karaqkouni A, Kourembanas S, Theorides TC. Perinatal stress, brain inflamation and risk autismo-review and proposal. BMC Pediatr. 2012 Jul 2;12;89. Doi: 10.1186/1471-2431-12-98.

Aron AR, Robbins TW, Poldrack RA. Inhibition and the right inferior frontal cortex. Trends Cogn Sci 2004;8(4):170-7.

Avery D, George MS. International Society of Transcranial Stimulation (ISTS), Database for studies of transcranial magnetic stimulation in the treatment of depression. Electroenceph Clin Neurophysiol 1998;107:93P. 
Barker AT, Jalinous R, Freeston IL. Non-invasive magnetic stimulation of human motor cortex. Lancet 1985 11;1(8437):1106-7.

Barr MS, Farzan F, Tran LC, Fitzqerald PB, Daskalakis ZJ. A randomized controlled trial of sequentially bilateral prefrontal cortex repetitive transcranial magnetic stimulation in the treatment of negative symptoms in schizophrenia. Brain Stimul 2012;5(3):337-46.

Baruth JM, Casanova MF, El-Baz A, Horrell T, Mathai G, Sears L, Sokhaze E. Low-Frequency Repetitive Transcranial Magnetic Stimulation (rTMS) Modulates Evoked-Gamma Frequnacy Oscilations in Autism Spectrum Disorder. J Neurother 2010 July 1;14(3):179-194.

Bearss K, Lecavalier L, Minshawi, N, Johnson, C, Smith, T, Handen, B, Sukhodolsky, D, Aman, M, Swiezy, N, Butter, E, Scahill, L. Toward an exportable parent training program for disruptive behavior in autism spectrum disorder. Neuropsychiatry (London) 2013 Apr;3(2):169-180.

Ben-Shachar D, Gazawi H, Riboyad-Levin J, Klein E. Chronic repetitive transcranial magnetic stimulation alters beta adrenergic and 5-HT2 receptor characteristics in rat brain. Brain Res 1999, 816:78-83.

Bilder D, Pinborough-Zimmerman J, Miller J, Mcmahon W. in Prenatal, perinatal and neonatal factors associated with autism spectrum disorder. Pediatrics 2009;135(5):1293-300.

Boddaert N, Belin P, Chabane N, Poline JB, Barthelemy C, Mouren-Simeoni MC. Perception of complex sounds: abnormal pattern of cortical activation in autism. Am J Psychiatry. 2003;160(11):2057-60. 
Boddaert N, Chabane C, Belin P, Bourgeois M, Royer V, Bathelemy C. Perception of complex sounds in autism: abnormal auditory cortical processing in children. Am J Psychiatry. 2004;161(11):2117-20.

Bodfish JW, Symons FJ \& Lewis MH. The Repetitive Behavior Scales. Western Carolina Center Research Reports, 1999

Boyd BA, Mcbee M, Holtzclaw T, Baranek GT, Bodfish JW. Relationships among repetitive behaviors, sensory features, and executive functions in high functioning autism. Research in Autism Spectrum Disorders 3 (2009) 959-966

Bor J, Brunelin J, Rivet A, D'amato T, Poulet E, Saoud M, Padberg F. Effects of theta burst stimulation on glumatamate levels in a patient with negative synptoms of Schizophrenia. Schizofrenia Research 111 (2009) 196-197.

Boraston Z, Blakmore SJ, Chivres R, Skuse D. Impaired sadness recognition is linked to social interaction deficit in autism. Neuropsychologia 2007 45(7): 1501-10.

Boravova A.L. Activity of the neurons of the medial region of the septum of the rabbit brain in early ontogenesis. Neurosci Behav Physiol 1976 Jan-Mar;7(1):49-55.

Braunschweig D, Krakowiak P, Duncanson P, Boyce R, Hansen RL, Ashwood P, Hertz-Picciotto I, Pessah IN, Van De Walter J. Autism-specific maternal autoantibodies recognize critical proteins in developing brain. Transl Psychiatry $2013-3$, e277.

Brimacombe M, Ming X, Lamendola M. Prenatal and birth complications in autism. Matern Child Health J 2007;11(1):73-9. 
Butler MG, Dasouki MJ, Zhou XP, Talebizadeh Z, Brown M, Takahashi TN, Miles JH, Wang CH, Stratton R, Pilarski R, Eng C. Subset of individuals with autism spectrum disorders and extreme macrocephaly associated with germline PTEN tumour suppressor gene mutations. J Med Genet 2005;42:318-321.

Buzsáki G, Chen LS, Gage FH. Spacial organization of physiological activity in hippocampal region: relevance to memory formation. Prog Brain Res 1990;83:257-68.

Campbell DB, Sutcliffe JS, Ebert PJ, Militerni R, Bravaccio C, Trillo S, Elia M, Schneider C, Melmed R, Sacco R, Persico AM, Levitt P. A genetic variant that disrupts MET transcription is associated with autism. Proc Natl Acad Sci USA 2006;103:16834-16839.

Camprodon JA, Martinez-Raga J, Alonso M, Shih MC, Pascual-Leone A. One session of high frequency repetitive transcranial magnetic stimulation (rTMS) to the right prefrontal cortex transiently reduces cocaine craving. Drug Alcohol Depend 86(1):91-4, 2007.

Casanova MF, Van Kooten AJ, Switala AE, Van Engeland H, Heisen H, Steinbusch HWM, Trippe J, Stone J, Schmitz C. Minicolunar abnormalities in Autism. Acta Neuropathol (2006) 112:287-303.

Casanova MF. The Neuropathology of autism. Brain Pathol. 2007 Oct;17(4):422-33.

Casanova MF, El-Baz A, Vanbogaert E, Narahari P, Switala A. A topographic Study of Minicolumnar core width by lamina comparison between autistic subjects and controls: possible minicolumnar disruption due to na anatomical element in-cammon to multiple laminae. Brain Pathology (20) 2010 451-458 
Center for Disease Control and Prevention. Prevalence of autism spectrum disordersautism and developmental disabilities monitoring network, 14 sites, United States, 2002. Autism and Developmental Disabilities Monitoring Network Surveillance Year 2002 - 2007 MMWR Surveill Summ 56:12-28.

Cheng Y, Chou KH, Chen IY, Fan YT, Decety J, Lin CP. Atypical development of white matter microstructure in adolescents with autism spectrum disorders. Neuroimage 2010 Apr 15;50(3):873-82.

Coarkin PE, Wall CA, King JD, Andrew Kozel F, Daskalakis ZJ. Pain during transcranial magnetic stimulation in youth. Innov Clin Neurosci 2011;8(12):18-23.

Cohen LG, Sato S, Rose D, Kufta C, Bandinelli S, Hallett M. Correlation of transcranial magnetic stimulation (TCMS), direct cortical stimulation (DCS) and somatosensory evoked potentials (SEP) for mapping od hand motor representation area (HMRA). Neurology 1989;39 (Suppl 1):375.

Cohen LG, Roth BJ, Nilsson J, Dang N, Panizza M, Bandielli S, Friauf W, Hallett M. Effects of coil design on delivery of focal magnetic stimulation. Technical considerations. Electroencephalogr Clin Neurophysiol 1990;75(4):350-7.

Cortesi F, Giannotti F, Sebastian T, Panunzi S, Valente D. Controlled-release melatonin, singly and combined with cognitive behavioural therapy, for persistent insomnia inchildren with autism spectrum disorder: a randomized placebo-controlled trial. J Sleep Res. 2012 Dec;21(6):700-9.

Counter SA. Neurobiological effects of extensive transcranial electromagnetic stimulation in an animal model. Electroencephalogr Clin Neurophysiol 1993;89:341-348.

Courchesne E, Carper R, Akshoomoff N. Evidence of brain overgrowth in the first year of life in autism. Jama 2003;290:337-344. 
Demirtas-Tatlidede A, Vahabzadeh-Hagh AM, Pascual-Leone, A. Can noninvasive brain stimulation enhance cognition in neuropsychiatric disorder? Neuropharmacology 2013 Jan;64:566-78.

Dichter GS, Richey JA, Rittenberg AM, Sabatino A, Bodfish JW. Reward circuitry function in autism during face anticipation and outcomes. J Autism Dev Disord. 2012;42:147-160.

Durand CM, Betancur C, Boeckers TM, Bockmann J, Chaste P, Fauchereau F, Nygren G, Rastam M, Gillberg IC, Anckarsater H, Sponheim E, Goubran-Botros H, Delorme R, Chabane N, Mouren-Simeoni M.C, De Mas P, Bieth E, Roge B, Heron D, Burglen L, Gillberg C, Leboyer M, Bourgeron T. Mutations in the gene encoding the synaptic scaffolding protein SHANK3 are associated with autism spectrum disorders. Nat Genet 2007;39:25-27.

Eyre JA, Taylor JP, Villagra F. Evidence of activity-dependent withdrawal of corticospinal projections during human development. Neurology 2001;57:1543-1554.

Elsabbagh M, Divan G, Koh YJ, Kim YS, Kauchali S, Marcín C, Montiel-Nava C, Patel V, Paula CS, Wang C, Yasamy MT, Fombonne E. Global Prevalence of Autism and Other Pervasive Developmental Disorder. Autism Res 2012, 5:160-179.

Enticott PG, Rinehart NH, Tonge BL, Bradshaw JL, Fitzgerald PB. Repetitive transcranial magnetic stimulation (rTMS) improves movement-related cortical potentials in autism spectrum disorder. Brain Stimul 2012 Jan;5(1):30-7.

Esbensen AJ, Seltzer MM, Lam KSL, Bodfish JW. Age-Related Differences in Restricted Repetitive Behaviors in Autism Spectrum Disorder. J Autism Dev Disord 2009 39:57-66. 
Farley, M.A, Mcmahon, W.N, Fombonne, E, Jenson, W.R, Miller, L, Gardner, M, Block, H, Pinqree, C.B, Ritvo, E.R, Ritvo, R.A, Coon, H. Twenty-year outcome for individuals with autism and average or near-average cognitive abilities. Autism Res. 2009 Apr;2(2):109-18.

Fecteau S, Agosta S, Oberman L, Pascoal-Leone A. Brain stimulation over Broca's area differentially modulates naming skills in neurotypical individuals with Asperger's syndrome. Eur J Neurisc 2011;34:158-164.

Ferreira ABH. Dicionário Aurélio Básico da Língua Portuguesa. Rio de janeiro. Editora Nova Fronteira, 1988.

Feng J, Schroer R, Yan J, Song W, Yang C, Bockhold A, Cook EH, Skinner C, Schwartz CE, Sommer SS. High frequency of neurexin 1beta signal peptide structural variants in patients with autism. Neurosci Lett 2006;409:10-13.

Fombonne E. Epidemiology of pervasive developmental disorder. Pediatric Research 2009;65,591-598.

Frazier TW, Youngstrom EA, Speer L, Embacher R, Law P, Constantino J, Findling RL, Hardan AY, Eng C. Validation of Proposed DSM-5 Criteria for Autism Spectrum Disorder. J Am Acad Child Adolesc Psychiatry. 2012 January ; 51(1): 28-40.e3

Frith U. Autism and Asperger Syndrome. Cambrige. Cambrige University Press, 1991.

Frye RE, Rotenberg A, Ousley M, Pascual-Leone A. Transcranial magnetic stimulation in child neurology: current and future directions. J Child Neurol 2008;23(1):79-96. 
Gabriel R, Agnew J, Miller J, Gralla J, Pan, Z, Goldson E. Is there a relationship between restricted, repetitive, stereotyped behaviors and interests and abnormal sensory response in children with autism spectrum disorders? Research in Autism Spectrum Disorders 2008 2, 660-670.

Gates JR, Dhuna A, Pascoal-Leone A. Lack of pathologic changes in human temporal lobes after transcranial magnetic stimulation. Epilepsia, v. 33, p. 504-8, 1992.

Gauderer EC. Autismo. Rio de Janeiro. Atheneu. $3^{0}$ edição, 1993.

Gervais H, Belin P, Boddaert N, Laboyer M, Coez A, Sfaello I. Abnormal cortical voice processing in autism. Nat Neurosci. 2004;7(8):801-2.

Gilberg C. Clinical Child Neuropsychiatry. Cambrige. Cambrige University Press, 1995.

Gilberg C, De Souza L. Head circumference in autism, Asperger syndrome, and ADHD: a comparative study. Dev Med Child Neurol; 44(5): 296-300, 2002 May.

Gilberg C, Coleman C. The Biology of the Autistic Syndromes. London. Ed. MacKeith, 1992.

Grossheinrich N, Rau A, Pogarell O, Hennig-Fast K, Reinl M, Karch S, Dieler A, Leicht G, Mulert C, Sterr A, Padberg F. Theta Burst Stimulation of the Prefrontal Cortex: Safety and Impacton cognition, mood, and Resting Eletroencefalogram. Biol Psychiatry 2009;65: 778-784.

Guse B, Falkai P, Wobrock T. Cognitive effects of high-frequency repetitive transcranial magnetic stimulation: a systematic review. J Neural Transm 2010; 117(1):105-22. 
Hamilton R, Messing S, Chatterjee A. Rethinking the thinking cap: ethics of neural enhancement using noninvasive brain stimulation. Neuroloy 2011;76(2):187-93.

Hang YZ, Rotherwell JC, Edwards MJ, Chen RS. Effect of Physiological Activity on an NMDA-Dependent Form of Cortical Plasticity in Human. Cerebral Cortex 2008; 18:563-570.

Happé F, Frith U. The neuropsychology of autism. Brain (1996), 119, 1377-1400.

Harsey D. Transcranial Magnetic Stimulation in Treatment of Mood Disorder: A Review and Comparison with Eletroconvulsive Therapy. 2001 Can J Psychiatry;46:720-727.

Hazlet HC, Poe M, Gerig G, Smith RG, Provenzale J, Ross A, Gilmore J, Piven J. Magnetic resonance imaging and head circumference study of brain size in autism: birth through age 2 years. Arch Gen Psychiatry 62:1366-1376, 2005.

Hazlet HC, Poe MD, Gerig G, Smith G, Piven J. Cortical gray and white brain tissue volume in adolescents and adults with autism. Biol Psychiatry 59(1): 1-6, 2006 Jan 1.

Hazby JV, Hoffman EA, Gobbini MI. The distributed human neural system for face perception. Trends Cogn Sci. 2000;4(6):223-33.

Heaton R, Chelune GJ, Talley JL, Kay GG, Curtiss G. Teste Wisconsin de Classificação de Cartas; adap. e padron. bras. Cunh, J.A. [et al]; SP: Casa do Psicólogo, 2005.

Hoffman RE, Hawkins KA, Gueorguie R, Boutros NN, Rachid F, Carroll K, Krystal JH. Transcranial magnetic stimulation of left temporoparietal cortex and medicationresistant auditory hallucinations. Arch Gen Psychiatry, v. 60, p. 49-56, 2003. 
Honda H, Shimizu Y, Misumi K, Niimi M, Ohashi Y. Cumulative incidence and prevalence of childhood autism in children in Japan. Br J Psychiatry 1996 169:228-235.

Howard MA, Cowell PE, Boecher J, Broks P, Mayes A, Farrant A. Convergent neuroanatomical and behavioural evidence of an amygdale hypothesis of autism. Neuroreport. 2000;11(13):2931-5.

Huang YZ, Edwards MJ, Rounis E, Bhatia KP, Rothwell JC. Theta Burst Stimulation of the Human Motor Cortex. Neuron 2005;45:201-206.

Huang YZ, Chen RS, Rothwell JC, Wen HY. The after-effect of human theta burst stimulation is NMDA receptor dependent. Clin Neurophy 2007;118:1028-1032.

Hubl D, Bolte S, Feineis-Mattheus S, Lanfermann H, Federspiel A, Strik W. Functional imbalance of visual pathways indicates alternative face processing strategies in autism. Neurology. 2003;61(9):1232-7.

Hudry K, Chandler S, Bedford R, Pasco G, Gliga T, Elsabbagh M, Johnson MH, Charman T. Early Language Profiles in Infants at High-Risk for Autism Spectrum Disorder. J Autism Dev Disord. 2013 jun 8 [Epub ahead of print]

Huerta PT, Volpe BT. Transcranial magnetic stimulation, synaptic plasticity and network oscillations. J Neuroeng Rehabil 2009;6:7.

Jamain S, Quach H, Betancur C, Rastam M, Colineaux C, Gilberg IC, Sonderstrom, H, Giros, B, Leboyer, M, Gillberg, C, Bourgeron, T. Mutations of the X-linked genes encoding neuroligins NLGN3 and NLGN4 are associated with autism. Nat Genet 2003;34:27-29. 
Jung MW, Larson J, Lynch G. Long-term potentiation of monosynaptic EPSPs in rat piriform cortex in vitro. Synapse 1990;6(3):279-83.

Jung HN, Janzarik WG, Delvendahl I, Münchau A, Biscaldi M, Mainberger F, Bäumer T, Rauh R, Mall V. Impaired induction of long term potentiation-like plasticity in patients with high-funtioning autism and Asperger syndrome. Dev Med Child Neurol 2013;55(1):83-9.

Kanner L. Autistic disturbances of affetive contact. Nervous Child, 2:217-251, 1943.

Karmel ZB, Gardner JM, Meade LS, Cohen IL, London E, Flory MJ, Lennon EM, Miroschnichenko I, Rabinowitz S, Parab S, Baeone A, Harin A. Early Medical and Behavioral Characteristics of NICU Infants Later Classified. Pediatrics $2010 ; 126 ; 457$

Kenneedy DP, Redcay E, Courchesne E. Faling to deactivate: resting functional abnormalities in Autism. Proc Natl Acad Sci USA 2006 May 23;103(21):8275-80.

Kong A, Frigge M.L, Masson G, Besenbacher S, Sulem P, Magnusson G, Gudjonsson SA, Sigurdsson A, Jonasdottir AD, Jonasdottir AS, Wong WS, Sgurdsson G, Walters GB, Steinberg S, Helgason H, Thorleifsson G, Gudbajartsson DF, Helgason A, Magnusson OTH, Thirteinsdottir U, Stefansson K. Rate of de novo mutations and the importance of father's age to disease risk. Nature 2012 Aug $23 ; 488(7412): 471-5$.

Kossev AR, Siggelkow S, Dengler R, Rollnik JD. Intracortical inhibition and facilitation in paired-pulse transcranial magnetic stimulation: effect of conditioning stimulus intensity on sizes and latencies of motor evoked potential. J Clin Neurophysiol, 2003 Feb;20(1):54-8. 
Kotaqal S, Broomall E. Sleep in children with Autism Spectrum Disorder. Pediatr Neurol. 2012 Oct; 47(4):242-51.

Kramer M, Sartorius N, Jablensky A, Gulbinat W. The ICD-9 classification of mental disorders. A review of its development and contents. Acta Psychiatr Scand 1979 Mar;59(3):241-62.

Lainhart JE, Bigler ED, Bocian M, Coon H, Dinh E, Dawson G, Deutsch CK, Dunn M, Estes A, Tager-Flusberg H, Folstein S, Hepburn S, Hyman S, Mcmahon W, Minshew N, Munson J, Osann K, Rodier P, Rogers S, Sigman M, Spence MA, Stodqell CJ, Volkmar F. Head circumference and height in autism: a study by the Collaborative Program of Excellence in Autism. Am J Med Genet A 2006;140(21):2257-74.

Lam KS, Bodfish JW, Piven J. Evidence for three subtypes of repetitive behavior that differ in familiality and association with other symptoms. J Child Psychol Psychiatry. 2008;49(11)1193-200.

Lang N, Speck S, Harm J, Rothkegel H, Paulus W, Sommer M. Dopaminergic potentiation of rTMS-induced motor cortex inhibition. Biol Psychiatry 2008, 63:231-233.

Larson J, Lynch G. Theta pattern stimulation and the induction of LTP: the sequence in which synapses are stimulated determines the degree to which they potentiate. Brain Res 1989;489(1):49-58.

Larson J, Wong D, Lynch G. Patterned stimulation at the theta frequency is optimal for the induction of hippocampal long-term potentiation. Brain Res 1986 Mar $19 ; 368(2): 347-50$. 
Leekam SR, Prior MR, Uljarevic M. Restricted and repetitive behaviors in autism spectrum disorders: A review of research in the last decade. Psychol Bull 2011 Jul;137(4):562-93.

Lewis MH, Bodfish JW. Repetitive behavior disorders in autism. Mental Retardation and Developmental Disabilities Research Reviews, 4, 80-89. doi:10.1002/(SICI)1098-2779 (1998)4:2180::AID-MRDD4[3.0.CO;2-0.

Lie CH, Specht K, Marshall JC, Fink GR. Using fMRI to decompose the neural processes underlying the Wisconsin Card Sorting Test. Neuroimage 2006 Apr 15;30(3):1038-49. Epub 2006 Jan 18.

Lindell AK, Hudry K. Atypicalities in Cortical Structure, Handedness, and Functional Lateralization for Language in Autism Spectrum Disorders. Neuropsychol Rev 2013 May.

Loo CK, Mitchell P, Sachdev P. Double-blind controlled investigation of transcranial magnetic stimulation for the treatment of major depression. Am J Psychiatry 1999;156:946-8.

Lopes BR, Lincoln AJ, Ozonoff S, Lai Z. Examining the relationship between Executive Functions and Restrited, Repetitive Symptoms of Autistic Disorder. $J$ Autism Dev Dis 2005;35:4 445-460.

Mahajan R, Bernal MP, Panzer R, Whitaker A, Roberts W, Handen B, Hardan A, Anaqnostou E, Veenstra-Vanderweele J. Autism Speaks Treatment Network Psychopharmacology Committee. Clinical practice pathways for evaluation and medication choice for attention-deficit/hyperactivity disorder symptoms in autism spectrum disorder. Pediatrics 2012 Nov;130:2:S125-38. 
Mantovani A, Simpson H.B, Fallon B.A, Rossi S, Lisanby SH. Randomized shamcontrolled trial of repetitive transcranial magnetic stimulation in treatment-resistant obsessive-compulsive disorder. International Journal of Neuropsychopharmacology. 2010;13, 217-227.

Marcolin MA. Edição especial estimulação magnética transcraniana. Revista de Psiquiatria Clínica 2004;31:209-209.

Mccaffery P, Deutsch CK. Macrocephaly and the control of brain growth in autistic disorder. Prog Neurobiol 2005;77(1-2):38-56.

Mcconnell KA, Nahas Z, Shastri A, Lorberbaum P, Kozel F.A, Bohning DE, George MS. The Transcranial Magnetic Stimulation Motor Threshold Depends on the Distance from Coil to Underlying Cortex: A Replication in Healthy Adults Comparing Two Methods of Assessing the Distance to Cortex. Biol Psychiatry 2001;49:454-459.

Mcdougle CJ, Kresch LE, Goodman WK, Naylor ST. A case-controlled study of repetitive thoughts and behavior in adults with autistic disorder and obsessivecompulsive disorder. Am J Psychiatry. 1995;152(5):772-7.

Mcpartland J, Dawson G, Webb SJ, Panagiotides H, Carver LJ. Event-related brain potentials reveal anomalies in temporal processing of faces in autism spectrum disorder. J Child Psychol Psychiatry 2004;45(7):1235-45.

Mentzel HJ, Gaser C, Volz HP, Rzanny R, Häger F, Sauer H, Kaiser WA. Cognitive stimulation with the Wisconsin Card Sorting Test: functional MR imaging at $1.5 \mathrm{~T}$. Radiology 1998 May;207(2):399-404. 
Miles JH, Hadden LL, Takahash TN, Hillman RE. Head circumference is an independent clinical finding associated with autism. Am J Med Genet 2000;95:339-350.

Mirenda PL, Donnellan AM, Yoder DE. Gaze behavior: a new look at anold problem. J. Autism Dev. Disord., 13: 397-409, 1983.

Mochizuki H, Furubayashi T, Hanajima R, Terao Y, Mizuno Y, Okabe S, Ugawa Y. Hemoglobin concentration changes in the contralateral hemisphere during and after theta burst stimulation of the human sensoriomotor córtices. Exp Brain Res 2007;180:667-675.

Monchi O, Petrides M, Petre V, Worsley K, Dagher A. Wisconsin Card Sorting Revised: Distinct Neural Circuits Participating in Different Stages of the Task Identified by Event-Related Functional Magnetic Resonance Imaging. T J Neurosc 2001;21(19):7733-7741.

Mosconi MW, Mack PB, Mccarthy G, Pelphrey KA. Taking an intentional stance on eye-gaze shifts: a functional neuroimaging study of social perception in children. Neuroimage 2005;27(1):247-52.

Mosconi MW, Kay M, D'cruz AM, Seidenfeld A, Guter, S Stanford LD, Sweeney, J.A. Impaired inhibitory control is associated with higher-order repetitive behaviors in autism spectrum disorder. Psychological Medicine 2009;39,1559-1566.

Mosconi MW, Cody-Hazlett H, Poe MD, Gerig G, Gimpel-Smith R, Piven J. Longitudinal study of amygdala volume and joint attention in 2- to 4-year-old children with autism. Arch Gen Psychiatry 2009;66:509-516.

Moster D, Lie RT, Markestad T. Long-term medical and social consequences of preterm birth. N Engl J Med 359 (3) (2008), pp. 262-273. 
Mountcastle VB. The columnar organization of the neocortex. Brain 1997;120:701-722.

Nicolson R, Devito TJ, Vidal CN, Susi Y, Hayashi KM, Drost DJ. Williamson PC, Rajakumar N, Toga AW, Thompson, P.M. Detection and mapping of hippocampal abnormalities in autism. Psychiatry Res. 2006 (1): 11-21, 2006 Nov 22.

Nie T, Mcdonough CB, Hunag T, Nguven PV, Abel T. Genetic Disruption of Protein Kinase A Anchoring Revels a Role for Compartmentalized Kinase Signaling in Theta-Burst Long Term Potentiation and Spatial Memory. $T J$ Neurosci 2007;27(38):10278-10288.

O'hearn K, Asato M, Ordaz S, Luna B. Neurodevelopment and executive function in Autism. Dev Psychopathol. 2008;20(4)1103-32.

Organização Mundial de Saúde (OMS). Classificação de Transtornos Mentais e do Comportamento da CID 10 - Descrições Clínicas e Diretrizes Diagnósticas. Porto Alegre. Artes Médicas, 1993.

Otto T, Eichenbalim H, Wiener SI, Wible CG. Learning-Related Patterns of CA1 Spike Trains Parallel Stimulation Parameters Optimalfor Inducing Hippocampal Long-Term Potentiation. Hippocampus 1991 1:181-192.

Padberg F, Zwanzger P, Thoma H, Kathmann N, Haag C, Greenberg BD. Repetitive transcranial magnetic stimulation (rTMS) in pharmacotherapy-refractory major depression: comparative study of fast, slow and sham rTMS. Psychiatry Res 1999;88 (3):163-71.

Pascoal-Leone A, Wassermann EM, Grafman J, Hallett M. The role of the dorsolateral prefrontal cortex in implicit procedural learning. Exp Brain Res 1996;107(3):479-85. 
Pascual-Leone A, Rubio B, Pallardo F, Catala MD. Beneficial effect of rapid-rate transcranial magnetic stimulation of the left dorsolateral prefrontal cortex in drugresistant depression. Lancet 1996a;348:233-7.

Pascual-Leone A, Catala Md, Pascual AP. Lateralized effect of rapid-rate transcranial magnetic stimulation of the prefrontal cortex on mood. Neurology 1996b; 46:499-502.

Pascual-Leone A, Meador KJ. Is transcranial magnetic stimulation coming of age? (guest editorial). J clin Neurophysiol 1998 ;5 (4):285-6.

Pascual-Leone A, Davey NJ, Rothwell J, Wassermann EM, Puri BK. Handbook of transcranial magnetic stimulation. New York: Oxford University Press, 2002.

Patel V, Garrison P, Mari JJ, Minas H, Prince M, Saxena S. Advisory group of the Movement for Global Mental Health. The Lancet's series on global mental health: 1 year on. Lancet. 2008 372, 1354-1357.

Pascual-Leone A, Houser CM, Reese K, Shotland Li, Grafman J, Sato S. Safety of rapid-rate transcranial magnetic stimulation in normal volunteers. Electroencephalography and clinical Neurophysiology 1993;89:120-30.

Paula CS, Ribeiro SH, Fombonne E, Mercadante MT. Brief Report: Prevalence of Pervasive Developmental Disorder in Brazil: A Pilot Study. J Autism Dev Disord (2011) 41:1738-1742.

Paus T, Jech R, Thompson CJ, Comeu R, Peters T, Evans A. Transcranial magnetic stimulation during positron emission tomography: a new method for studying connectivity of the human cerebral cortex. J Neurosci 1997;17:3178-84. 
Persico AM, Bourgeron T. Searching for ways out of the autism maze: genetic, epigenetic and environmental clues. Trends Neurosci 2006;29:349-358.

Peters A, Cifuentes JM, Sethares, C. The organization of pyramidal cells in area 18 of the rhesus monkey. Cereb Cortex 1997;7:405-421.

Politte LC, Mcdouqle CJ. Atypical antipsychotics in treatment of children and adolescents with pervasive developmental disorders. Psychopharmaclogy (Berl) 2013 Apr 4.

Post A, Keck ME. Transcranial magnetic stimulation as a therapeutic tool in psychiatry: what do we know about the neurobiological mechanisms? 2001 JulAug;35(4):193-215.

Rai D, Lee BK, Dalman C, Golding J, Lewis G, Magnusson C. Parental depression, maternal antidepressant use during pregnancy, and risk of autism spectrum disorder: population based case-control study. BMJ 2013;346:f2059.

Raynaud F, Janossy A, Dahl J, Bertaso F, Perroy J, Varrault A, Vidal M, Worley PF, Boeckers TM, Bockaert J, Marin P, Faqni L, Homburger V. Shank3-Rich2 interaction regulates AMPA receptor Recycling and synaptic long-term potentiation. J Neurosci 2013 5;33(23):9699-715.

RG C. What is autism? International Review of Psychiatry, 2: 61-66, 1990.

Ritivo ER, Freeman BJ. National Society for Autistic Children Definition of the Syndrome of Autism. J. Am. Acad. Child. Psych. 1978,17: 565-575. 
Rojas DC, Peterson E, Winterrowd E, Reite ML, Rogers SJ, Tregellas JR. - Regional gray matter volumetric changes in autism associated with social and repetitive behavior symptoms. BMC Psychiatry 6: 56, 2006.

Rossi S, Hallett M, Rossini PM, Pascual-Leone A. Safety of TMS Consensus Group. Safety, ethical considerations, and application guidelines for the use of transcranial magnetic stimulation in clinical practice and research. Clin Neurophysiol. 2009;120(12):2008-39.

Rossiqnol DA, Frye RE. Melatonin in Autism Spectrum Disorder: a systematic review and meta-analysis. Dev Med Child Neurlo. 2011 Sep;53(9):783-92.

Rutter M, Schopler E. Autism: a reappraisal of concepts and treatment. New York. Diagnosis and definitions Plenum, p. 1978;1 -25.

Rutter M, Bartak L. Causes of infantile autism: some considerations from recent research. J Autism Child Shizophrenia, 1971 1(1):20-32.

Rutter M, Hersov L. Child and Adolescent Psychiatry. London. Blackwell Scientific Publicaitons, $19923^{\circ}$ ed.

Rutter M, Schopler E. Autism and pervasive developmental disorders: concepts and diagnostic issues. J Autism Dev Disord, 1987;17: 159-186.

Samson F, Hyde KL, Bertone A, Soulières I, Mendrek A, Ahad P, Mottron L, Zeffiro TA. Atypical processing of auditory complexity in autistics. Neuropsychologia 49 (2011) 546-555.

Schanen NC. Epigenetics of autism spectrum disorders. Hum Mol Genet 15 (2) (2006), pp. R138-R150. 
Schopler E, Mesibov G. Autism in adolescents and adults. New York. Plenum Publ. Co., 1984.

Schultz RT, Gauthier I, Klin A, Fubright RK, Anderson AW, Volkmar F. Abnormal ventral temporal cortical activity during face discrimination among individuals with autism and Asperger syndrome. Arch Gen Psychiatry. 2000;57(4):331-40.

Schumann CM, Nordahl CW. Bridging the gap between MRI and postmortem research in Autism. Brain Res 20111380 175-186.

Sgro JA, Ghatak NR, Stanton PC. Repetitive high magnetic field stimulation: the effect upon rat brain. Electroencephalogr Clin Neurophysiol Suppl 1991;43:180-185.

Shafritz KM, Ditcher GS, Baranek GT, Belger A. The Neural Circuitry Mediating Shifts in Behavioral Response and Cognitive Set in Autism. Biol Psychiatry 2008;63:974-980.

Sharma S, Woolfson LM, Hunter SC. Confusion and inconsistency in diagnosis of Asperger syndrome: a review of studies from 1981 to 2010. Autism 2011:16(5) 465-486.

Siegel M. Psychopharmacology of autismo spectrum disorder: evidence and practice. Child Adolesc Psychiatr Clin N Am 2012 Oct;21(4):957--73

Sokhadze E, El-Baz A, Baruth J, Mathai G, Sears L, Casanova MF. Effects of Low Frequancy Repetitive Transcranial Magnetic Stimulation (rTMS) on Gamma Frequency Oscyllations and Event-Related Potentials During Processing Illosory Figures in Autism. J Autism Dev Disord 2009;39:619-634. 
Sokhadze E, Baruth, Tasman A, Mansoor, Mehreen M, Ramaswamy R, Sears L, Mathai G, El-Baz A, Casanova MF. Low-Frequency Repetitive Magnetic Stimulation (rTMS) Affects Event-Related Potential Measure of Novelty Processing in Autism. Appl Psychophisiol Biofeedback 2010;35:147-161.

Sokhadze EM, Baruth JM, Sears L, Sokhaze GE, El-Baz AS, Casanova MF. Prefrontal Neurmodulation Using rTMS Improves Error Monitoring and Correction Function in Autismo. Appl Psychophysiol Biofeedback 2012 37:91-102.

South M, Ozonoff S, Mcmahon WM. The relationship between executive functioning, central coherence, and repetitive behaviors in the high-functioning autism spectrum. Autism 2007 Sep;11(5):437-51

Takeucho K, Gertner MJ, Zhou J, Parada LF, Bennett MVL, Zukin RS. Dysregulation of synaptic plasticity precedes appearance of morphological defects in a Pten conditional knockout mouse model of autism. Proc Natl Acad Sci USA 2013;110(12):4738-43.

Thakkar KN, Polli FE, Joseph RM, Tuch DS, Hadjikhani N, Barton JJB, Manoach DS. Response monitoring, repetitive behavior and anterior cingulate abnormalities in ASD. Brain 2008; 131(Pt 9):2464-78.

Thomas MS, Knowland VC, Karmiloff-Smith A. Mecanisms of development regression in autism and broader phenotype: a neural network modeling approach. Psychol Rev. 2011 Oct;118(4):637-54.

Triggs W, Mccoy K, Greer R, Rossi F, Bowers D, Kortenkamp S. Effects of left frontal transcranial magnetic stimulation on depressed mood, cognition, and corticomotor threshold. Biological Psychiatry 1999;45:1440-6. 
Tuchman R, Rapin I. Autism: A neurological disorder of early brain development. London: Mac Keith Press for the International Child Neurology Association (INCA); 2006.

Tuner M. Annotation: Repetitive Behavior in Autism: A Review of Psychological

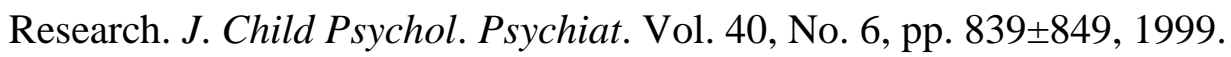

Vaccarino FM, Grigorenko EL, Smith KM, Stevens H. Regulation of cerebral cortical size and neuron number by Fibroblast Growth Factors: implications for Autism. J Autism Dev Disord. 2009 March ; 39(3): 511-520.

Valkanova V, Rhodes F, Allan CL. Diagnosis and management of autism in adults. Practitioner 2013 May;257(1761):13-6, 2-3.

Vidal CN, Nicolson R, Devito TJ, Hayashi KM, Geaga JA, Drost DJ, Williamson PC, Rajakumar N, Sui Y, Dutton RA, Toga AW, Thompson PM. Mapping corpus callosum deficits in autism: an index of aberrant cortical connectivity. Biol Psychiatry 60(3): 218-25, 2006 Aug 1.

Zilbovicius M, Meresse I, Boddaert N. Autismo: Neuroimagem. Rev. Brás. Psiquiatr. 2006;28 suppl 1:S21-8.

Zhou Q, Poo MM. R Reversal and consolidation of activity-induced synaptic modications. Trends Neurosci 2004;27(7):378-83.

Wegiel J, Kuchna I, Nowicki K, Imaki H, Wegiel JA, Marchi E, Yong MAS, Chauhan A, Borbowiczt W, Leon M, Louis LAS, Cohen IL, London E, Brown LT, Wisniewiski T. The neuropathology of autism: defects of neurogenesis and neurnal migration, and dysplastic changes. Acta Neuropathol 2010 119:755-770 
Welsh JP, Ahn E.S, Placantonakis DG. Is Autism duo to brain desynchronization. Int J Dev Neurosci. 2005 Apr-May;23(2-3):253-63.

Wing L, Gilbert C. The diagnosis and treatment of autism. New York. Plenum Press, 1989.

Wolf JJ, Gu H, Gerig G, Elison JT, Styner M, Gouttard S, Botteron KN, Dager SR, Dawson G, Estes AM, Evans AC, Hazlett HC, Kostopoulos P, Mckinstry RC, Paterson SJ, Schultz RT, Zwaigenbaum L, Piven J. Differences in White Matter fiber tract development present from 6 to 24 months in infants with Autism. Am J Psychiatry 2012 169:589-600.

Wong VC, Hui SL. Epidemiological study of autism spectrum disorder in China. J Child Neurol 2008 23:67-72

Word Health Organization (WHO). mhGAP Mental Health Gap Action Programme Scaling up care for mental, neurological, and substance use disorders. Geneva. 2008.

Wu SW, Shahana N, Nuddleston DA, Lewis AN, Gilbert DL. Safety and tolerability of theta-burst transcranial magnetic stimulatiom in children. Dev Med Child Neurol 2012;54(7):636-9. 